\title{
REFERENCE INDEX
}

Abelson, R. P. Spectral analysis and the study of individual differences in the performance of routine, repetitive tasks. Princeton, N.J.: Educ. Test. Serv., 1953. (9, 619)

Abood, L. G., Ostfeld, A., and Biel, J. H. Structureactivity relationships of 3-piperidyl benzilates with psychotogenic properties. Arch. int. Pharmacodyn., 1959, 120, 186-200. (6, 271)

Adam, G. Sur le role de l'écorce motrice dans la régulation du fonctionnement rénal. Acta Physiol., Hung., 1958, 13, 321-327. (8, 405)

Adam, G. and Meszaros, I. On the interoceptive conditioned cerebral electrical activation of reticular origin. EEG clin. Neurophysiol., 1962, 14, 106-114. $(8,405)$

Ader, R. and Clink, D. W. Effects of chlorpromazine on the acquisition and extinction of an avoidance response in the rat. J. Pharmacol. exp. Therap., 1957, 121, 144-148. (6, 213)

Ader, R. and Sibetta, J. Temporal parameters in the acquisition of a free-operant avoidance response in human subjects. Psychon. Sci., 1964, 1, 385-386. (9, 557)

Adler, H. E. and Dalland, J. I. Spectral thresholds in the starling (Sturnus vulgaris). J. comp. physiol. Psychol., 1959, 52, 438-445. (4, 149)

Adler, N. and Hogan, J. A. Classical conditioning and punishment of an instinctive response in Betta splendens. Animal Behav., 1963, 11, 351354. (8, 341; 8, 397; 10, 213)

Alexander, H. W. and Smith, R. F. Elementary statistics: a self-instruction program. Richmond, Ind.: Earlham College, 1960. (4, 202)

Alles, G. A. The comparative physiological actions of $d l$ - $\beta$-phenylisopropylamines. J. Pharmacol. exp. Therap., 1933, 47, 339-354. (3, 293)

Amer. Tel. \& Tel. Corp. Bell System Data Communications. Data sets 402A and 402B interface specifications. New York: AT\&T, 1963. $(9,507)$

Amoroso, E. C. and Marshall, F. H. A. External factors in sexual periodicity. In A. S. Parkes (Ed.), Marshall's physiology of reproduction. Vol. 1, Pt. 2. New York: Longmans, Green, 1960. Pp. 707-831. (10, 219)

Amsel, A. and Maltzman, I. The effect upon generalized drive strength of emotionality as inferred from the level of consummatory response. J. exp. Psychol., 1950, 40, 563-569. (6, 209; 7, 409; 8, 135)

Amsel, A. and Roussel, J. Motivational properties of frustration: I. Effect on a running response of the addition of frustration to the motivational complex. J. exp. Psychol., 1952, 43, 363368. $(6,155 ; 9,191 ; 10,45 ; 10,349)$
Amsel, A. The role of frustrative nonreward in non-continuous reward situations. Psychol. Bull., 1958, 55, 102-119. (7, 135; 9, 155; 9, 205; 10,$45 ; 10,349$ )

Amsel, A. Frustrative nonreward in partial reinforcement and discrimination learning: some recent history and a theoretical extension. Psychol. Rev., 1962, 69, 306-328. (7, 135; 9, 155; 9, 205; 9, 613)

Amsel, A. and Ward, J. S. Frustration and persistence: resistance to discrimination following prior experience with the discriminanda. Psychol. Monogr., 1965, 79 (4, Whole No. 597). $(9,155)$

Anand, B. K., Dua, S., and Singh, B. Electrical activity of the hypothalamic "feeding centers" under the effect of changes in blood chemistry. EEG clin. Neurophysiol., 1961, 13, 54-59. (10, 571)

Anand, B. K., Chhina, G. S., and Singh, B. Effect of glucose on the activity of hypothalamic "feeding centers." Science, 1962, 138, 597-598. $(10,571)$

Anand, B. K., Chhina, G. S., Sharma, K. N., Dua, S., and Singh, B. Activity of single neurons in the hypothalamic feeding centers: effect of glucose. Amer. J. Physiol., 1964, 207, 1146-1154. $(10,571)$

Anderson, A. C. Time discrimination in the white rat. J. comp. Psychol., 1932, 13, 27-55. (10,67)

Anderson, A. C. The effect of equalizing reward upon the breakdown of a discrimination habit, and its bearing upon reminiscence. J. comp. Psychol., 1937, 23, 421-437. (5, 15)

Anderson, N. H. and Grant, D. A. A test of a statistical learning theory model for two-choice behavior with double stimulus events. J. exp. Psychol., 1957, 54, 305-317. (6, 203)

Andersson, B. and Jewell, P. A. The distribution of carotid and vertebral blood in the brain and spinal cord of the goat. Quart. J. exp. Physiol., 1956, 41, 462-474. (7, 263)

Andersson, B. and Wyrwicka, W. The elicitation of a drinking motor conditioned reaction by electrical stimulation of the hypothalamic "drinking area" of the goat. Acta Physiol. Scand., 1957, 41, 194-198. (7, 263)

Andrew, R. J. Normal and irrelevant toilet behavior in Emberiza Spp. Brit. J. Animal Behav., 1956, 4, 85-91. $(7,351)$

Andy, O. J. General discussion following chapters 33-35. In $\mathrm{H}$. Jasper (Ed.), Reticular formation of the brain. Boston: Little, Brown, 1958. Pp. 722-727. $(10,571)$

Anger, D. The dependence of responding upon the 
relative frequency of reinforcements following different interresponse times. Amer. Psychologist, 1954, 9, 321-322. (Abstract) $(6,477)$

Anger, D. The effect upon simple animal behavior of different frequencies of reinforcement. Document No. 7779, ADI, Auxiliary Publications Project, Library of Congress, Washington, D.C., 1954. (See Anger, J. exp. Psychol., 1956)

Anger, D. The dependence of interresponse times upon the relative reinforcement of different interresponse times. J. exp. Psychol., 1956, 52, 145-161. (1, 45; 1, 59; 1, 109; 2, 1; 2, 91; 3, 93; 4,$219 ; 4,263 ; 4,387 ; 5,105 ; 5,175 ; 5,473$; 6,$109 ; 6,163 ; 6,237 ; 6,281 ; 6,399 ; 6,437$; 6,$477 ; 7,27 ; 7,273 ; 7,369 ; 7,391 ; 7,415$; 8,$9 ; 8,19 ; 8,107 ; 8,255 ; 8,269 ; 8,347 ; 9$, $65 ; 9,87 ; 9,317 ; 9,421 ; 9,581 ; 10,57 ; 10,425)$

Annau, Z. and Kamin, L. J. The conditioned emotional response as a function of intensity of the US. J. comp. physiol. Psychol., 1961, 54, 428-432. (8, 89; 8, 279; 9, 205)

Antonitis, J. J. Variability of response in the white rat during conditioning and succeeding extinction and reconditioning. Doctoral dissertation, Columbia, 1950. (1, 109; 1, 229; 4, 317; 5, 481; 6, 179; see also Antonitis, J. exp. Psychol., 1951)

Antonitis, J. J. Response variability in the white rat during conditioning, extinction, and reconditioning. J. exp. Psychol., 1951, 42, 273-281. $(4,97 ; 4,243 ; 5,299 ; 5,481 ; 6,179 ; 7,351 ; 8$, 219)

Appel, J. B. Punishment in the squirrel monkey Saimiri sciurea. Science, 1961, 133, 36. (6, 249; $6,399 ; 7,409 ; 8,279 ; 10,95 ; 10,439 ; 10,451)$

Appel, J. B. Punishment and shock intensity. Science, 1963, 141, 528-529. (8, 135; 8, 389; 9, 521; $10,451)$

Appel, J. B. and Peterson, N. J. Punishment: effects of shock intensity on response suppression. Psychol. Rep., 1965, 16, 721-730. (9, 521; $10,95 ; 10,451)$

Aprison, M. H. and Ferster, C. B. Neurochemical correlates of behavior: I. Quantitative measurements of the behavioral effects of the seratonin precursor, 5-hydroxytryptophan. J. Pharmacol. exp. Therap., 1961, 131, 100-107. (6, 125)

Arnold, W. J. An exploratory investigation of primary response generalization. J. comp. Psychol., 1945, 38, 87-102. (7, 211)

Arnold, W. J. Simple reaction chains and their integration: I. Homogeneous chaining with terminal reinforcement. J. comp. physiol. Psychol., 1947, 40, 349-364. (5, 543)

Arnold, W. J. Simple reaction chains and their integration: II. Heterogeneous chaining with terminal reinforcement. J. comp. physiol. Psychol., 1947, 40, 427-440. (5, 543)

Arnstein, P., Cohen, D. H., and Meyer, K. F. Medication of pigeons with chlortetracycline in feed. J. Amer. Vet. Med. Assn., 1964, 145, 921. $(8,67)$

Aronson, L. R. Reproductive and parental behavior. In M. E. Brown (Ed.), The physiology of fishes. Vol. 2. Behavior. New York: Academic Press, 1957. Pp. 271-304. (7, 45)

Asdell, S. A. Patterns of mammalian reproduction. (2nd ed.) Ithaca: Cornell Univ. Press, 1964. $(10,219)$

Autor, S. M. The strength of conditioned reinforcers as a function of frequency and probability of reinforcement. Doctoral dissertation, Harvard, 1960. (5, 113; 5, 543; 6, 53; 7, 27; 7, $179 ; 8,243 ; 10,35 ; 10,87 ; 10,281 ; 10,331)$

Ayers, W. J. and Thompson, R. L. Properties of inter-response time distributions obtained during differential reinforcement of temporally spaced responses. Amer. Psychologist, 1961, $16,458 .(6,163)$

Ayllon, $T$. The application of reinforcement theory to ward behavior problems. Doctoral dissertation, Univ. Houston, 1959. (2, 323)

Ayllon, T. Some behavioral problems associated with eating in chronic schizophrenic patients. Paper read at APA, Chicago, Sept. 1960. (5, 343)

Ayllon, T. Intensive treatment of psychotic behavior by stimulus satiation and food reinforcement. Behav. Res. Ther., 1963, 1, 53-61. $(8,357)$

Ayrapetyants, E. Sh. Higher nervous function and the receptors of internal organs. Moscow: Akad. Nauk SSSR, 1952. (8, 405)

Azrin, N. H. and Lindsley, $O$. R. The reinforcement of cooperation between children. $J$. $a b$ norm. soc. Psychol., 1956, 52, 100-102. (4, 7; 5, $343 ; 7,327 ; 9,191 ; 9,691$ )

Azrin, N. H. Some effects of two intermittent schedules of immediate and non-immediate punishment. J. Psychol., 1956, 42, 3-21. (1, 183; 2, $161 ; 2,301 ; 3,123 ; 3,275 ; 4,57 ; 5,191 ; 6$, $141 ; 6,399 ; 6,507 ; 7,21 ; 7,293 ; 7,323 ; 8$, $89 ; 8,135 ; 8,269 ; 8,279 ; 9,205 ; 9,251 ; 9$, $327 ; 9,521 ; 10,439 ; 10,451$ )

Azrin, N. H. Temporal changes in behavior under punishment. Paper read at APA, Cincinnati, Sept. 1959. (2, 301)

Azrin, N. H. Use of rests as reinforcers. Psychol. Rep., 1960, 7, 240. (9, 191)

Azrin, N. H. Sequential effects of punishment. Science, 1960, 131, 605-606. (3, 123; 5, 229; 6, $407 ; 8,89 ; 8,269 ; 9,411 ; 9,521)$

Azrin, N. H. Time-out from positive reinforcement. Science, 1961, 133, 382-383. (6, 423; 7, 1; 7, 13; 
7,$369 ; 8,189 ; 8,305 ; 9,191 ; 9,267 ; 10,35 ; 10$, $75 ; 10,151 ; 10,367)$

Azrin, N. H., Holz, W. C., and Hake, D. F. Intermittent reinforcement by removal of a conditioned aversive stimulus. Science, 1962, 136, 781-782. (6, 249; 6, 449; 8, 31; 9, 267; 10, 95; 10, 291)

Azrin, N. H. Aggression. Paper read at APA, Los Angeles, Sept. 1964. (9, 19)

Azrin, N. H. and Holz, W. C. Punishment. In W. K. Honig (Ed.), Operant behavior: areas of research and application. New York: Appleton-Century-Crofts, 1966. Pp. 380-447. (8, 31; 8,$279 ; 9,411 ; 10,75 ; 10,87 ; 10,109 ; 10,291$; $10,301 ; 10,417 ; 10,451)$

Bacon, M. M., Rood, E. A., and Washburn, M. F. A study of affective contrast. Amer. J. Psychol., 1914, 25, 290-293. (8, 269)

Baer, D. M. The effect of withdrawal of positive reinforcement on an extinguishing response in young children. Child Develpm., 1961, 32, 67-74. $(3,155 ; 5,525)$

Baer, D. M. A technique for social reinforcement for the study of child behavior: behavior avoiding reinforcement withdrawal. Child Develpm., 1962, 33, 847-858. (8, 329)

Baer, D. M. and Sherman, J. A. Reinforcement control of generalized imitation in young children. J. exp. Child Psychol., 1964, 1, 37-49. (10, 405)

Baerends, G. P. and Baerends van Roon, J. An introduction to the study of the ethology of Cichlid fishes. Behavior, 1950, 2, 1-243. (7, 45)

Bahnsen, P., Jacobsen, E., and Thesleff, H. Studien über die Wirkung von $\beta$-Phenylisopropylaminsulfat (Mecodrin) auf normale Menschen. Klin. Wchnschr., 1938, 17, 1074-1078. (3, 293)

Bailey, C. J. and Miller, N. E. The effects of sodium amytal on an approach-avoidance conflict in cats. J. exp. Psychol., 1954, 45, 205-208. $(5,335)$

Bakay, L. The blood-brain barrier. Springfield, Ill.: Thomas, 1956. $(9,95)$

Baker, K. H. Pre-experimental set in distraction experiments. J. gen. Psychol., 1937, 16, 471-488. $(1,183)$

Baker, R. A. and Osgood, S. W. Discrimination transfer along a pitch continuum. J. exp. Psychol., 1954, 48, 241-246. (10, 3; 10, 17)

Baldwin, B. A., Wenzel, Bernice M., and Tschirgi, R. D. Effects of acute cerebral ischemia on EEG in the goat. Fed. Proc., 1963, 22, 639. (7, 263)

Bandura, A. Social learning through imitation. In M. R. Jones (Ed.), Nebraska symposium on motivation, 1962. Lincoln: Univ. Nebr. Press, 1962. Pp. 211-269. (10, 405)

Bare, J. K. The specific hunger for sodium chloride in normal and adrenalectomized white rats. J. comp. physiol. Psychol., 1949, 42, 242-253. $(9,111)$

Barger, G. and Dale, H. H. Chemical structure and sympathomimetic action of amines. J. Physiol., 1910, 41, 19-59. (3, 293)

Barlow, J. A. Secondary motivation through classical conditioning. Doctoral dissertation, Duke, 1952. (5, 335)

Barlow, J. A. Secondary motivation through classical conditioning: a reconsideration of the nature of backward conditioning. Psychol. Rev., 1956, 63, 406-408. (6, 477)

Barnes, G. W. and Kish, G. B. Reinforcing properties of the termination of intense auditory stimulation. J. comp. physiol. Psychol., 1957, 50, 40-43. $(2,23 ; 9,357)$

Barnett, S. A. The rat: a study in behavior. Chicago: Aldine, 1963. (9, 677)

Baron, A. Functions of CS and UCS in fear conditioning. J. comp. physiol. Psychol., 1959, 52, 591-593. (8, 279)

Baron, A. and Littman, R. A. Studies of individual and paired problem-solving behavior in rats: II. Solitary and social controls. Genet. Psychol. Monogr., 1961, 64, 129-209. (9, 691)

Baron, A. and Antonitis, J. Punishment and preshock as determinants of bar-pressing behavior. J. comp. physiol. Psychol., 1961, 54, 716-720. (6, 399)

Barrett, Beatrice $\mathrm{H}$. Reduction in rate of multiple ties by free operant conditioning methods. J. neru. ment. Dis., 1962, 135, 187-195. (8, 357)

Barry, J. J., Jr. and Harrison, J. M. Relation between stimulus intensity and strength of escape responding. Psychol. Rep., 1957, 3, 3-8. (1, 145; 1,$183 ; 2,23 ; 3,207 ; 6,361 ; 8,31 ; 8,117 ; 8$, $321 ; 9,267 ; 9,655$ )

Bartlett, N. R. and Macleod, S. Effect of flash and field luminance upon human reaction time. J. opt. Soc. Amer., 1954, 44, 306-311. (7, 309)

Baum, W. M. Choice in the rat as a function of probability and amount of reward. Doctoral dissertation, Harvard, 1966. (10, 67)

Bayer, E. Beiträge zur Zweikomponententheorie des hungers. Z. Psychol., 1929, 112, 1-54. (10, 387)

Beach, F. A. and Jordan, L. Sexual exhaustion and recovery in the male rat. Quart. J. exp. Psychol., 1956, 8, 121-133. (10, 219)

Beach, F. A. and Rabedeau, R. G. Sexual exhaustion and recovery in the male hamster. $J$. comp. physiol. Psychol., 1959, 52, 56-61. (10, 219)

Beach, F. A. Experimental investigations of speciesspecific behavior. Amer. Psychologist, 1960, 15, 1-18. (3, 339)

Beck, R. C. On secondary reinforcement and shock 
termination. Psychol. Bull., 1961, 58, 28-45. (5, $335 ; 6,75 ; 9,547$ )

Bedford, The Duke of. Parrots and parrot-like birds. Fond du Lac, Wisc.: All-Pets Books, 1954. $(5,265)$

Beeman, E. A. The effect of male hormones on aggressive behavior in mice. Physiol. Zool., 1947, 20, 373-405. (5, 511)

Behar, I., Cronholm, J. N., and Loeb, M. Auditory sensitivity of the rhesus monkey. J. comp. physiol. Psychol., 1965, 59, 426-428. (9, 135)

Behrend, E. R. and Bitterman, M. E. Probabilitymatching in the fish. Amer. J. Psychol., 1961, 74, 542-551. (7, 151)

Behrend, E. R. and Bitterman, M. E. Avoidance conditioning in the goldfish: exploratory studies of the CS-US interval. Amer. J. Psychol., 1962, 75, 18-34. $(6,47)$

Békésy, G. V. A new audiometer. Acta Oto-laryngol., 1947, 35, 411-422. (1, 31; 2, 227; 6, 219; 6, $563 ; 9,515 ; 10,261)$

Bekhterev, V. M. General principles of human reflexology. (Tr. E. and W. Murphy) New York: International, 1932. (10, 131; 10, 291)

Bell, F. R. Alkaline taste in goats assessed by the preference test technique. J. comp. physiol. Psychol., 1963, 56, 174-178. (7, 263)

Berger, F. M., Hendley, C. D., and Lynes, T. E. Pharmacology of the psychotherapeutic drug benactyzine ( $\beta$-dimethylaminoethyl benzilate hydorchloride). Proc. Soc. exp. Biol. Med., 1956, 92, 563-566. (2, 107)

Berkson, G. and Schusterman, R. J. Reciprocal food sharing of gibbons. Primates, 1964, 5, 1-10. $(9,691)$

Berlyne, D. E. The arousal and satiation of perceptual curiosity in the rat. J. comp. physiol. Psychol., 1955, 48, 238-246. (1, 341)

Berlyne, D. E. Conflict, arousal, and curiosity. New York: McGraw-Hill, 1960. (5, 185; 5, 279)

Berlyne, D. E. and Lewis, Judith L. Effects of heightened arousal on human exploratory behavior. Canad. J. Psychol., 1963, 17, 398-411. (9, 119)

Bermant, G. Rat sexual behavior: photographic analysis of the intromission response. Psychon. Sci., 1965, 2, 65-66. (10, 219)

Bernard, C. An introduction to the study of experimental medicine. New York: Dover, 1957 (orig. pub. 1865). $(9,19)$

Bernstein, B. M. and Cancro, L. P. The effect of two variables of avoidance conditioning on drug-behavior interaction. Psychopharmacologia, 1962, 3, 105-113. (10, 485)

Berrien, F. K. The effects of noise. Psychol. Bull., 1946, 43, 141-161. (1, 183)

Berryman, R., Wagman, W., and Keller, F. Chlorpromazine and the discrimination of responseproduced cues. In L. Uhr and J. G. Miller
(Eds.), Drugs and behavior. New York: Wiley, 1960. Pp. 243-249. (8, 315)

Bersh, P. J., Schoenfeld, W. N., and Notterman, J. M. The effect of reinforcement history on extinction after reconditioning. Science, 1950, 112, 743-745. (2, 1; 4, 133)

Bersh, P. J. The influence of two variables upon the establishment of a secondary reinforcer for operant responses. J. exp. Psychol., 1951, 41, 62-73. (5, 543)

Bevan, W. and Adamson, R. Reinforcers and reinforcement: their relation to maze performance J. exp. Psychol., 1960, 59, 226-232. (8, 269)

Bickford, R. G., Daly, D., and Keith, H. M. Convulsive effects of light stimulation in children. A.M.A. J. Dis. Child., 1953, 86, 170-183. (2, 43)

Biel, W. C. and Wickens, D. D. The effects of vitamin $B_{1}$ deficiency on the conditioning of eyelid responses in the rat. J. comp. Psychol., 1941, 32, 329-340. (9, 605)

Biel, J. H., Abood, L. G., Hoya, W. K., Leiser, H. A., Nuhfer, P. A., and Kluchesky, E. F. Central stimulants: II. Cholinergic blocking agents. J. org. Chem., 1961, 26, 4096-4103. (6, 271)

Bijou, S. W. The development of a conditioning methodology for studying experimental neurosis in the rat. J. comp. physiol. Psychol., 1942, 44, 91-106. $(10,291)$

Bijou, S. W. A study of "experimental neurosis" in the rat by the conditioned response technique. J. comp. Psychol., 1943, 36, 1-20. (9, 143)

Bijou, S. W. A systematic approach to an experimental analysis of young children. Child Develpm., 1955, 26, 161-168. (4, 233; 5, 279)

Bijou, S. W. Patterns of reinforcement and resistance to extinction in young children. Child Develpm., 1957, 28, 47-54. (1, 25)

Bijou, S. W. Methodology for an experimental analysis of child behavior. Psychol. Rep., 1957, $3,243-250$. (1, 25; 5, 279)

Bijou, S. W. A child study laboratory on wheels. Child Develpm., 1958, 29, 425-427. (3, 155)

Bijou, S. W. and Sturges, P. T. Positive reinforcers for experimental studies with childrenconsumables and manipulatables. Child Develpm., 1959, 30, 151-170. (4, 7; 5, 33)

Bijou, S. W. Discrimination performance as a baseline for individual analysis of young children. Child Develpm., 1961, 32, 163-170. (4, $7 ; 5,443 ; 6,459$ )

Bindra, D. The nature of motivation for hoarding food. J. comp. physiol. Psychol., 1948, 41, 397402. $(3,154)$

Bindra, D. and Blond, Joyce A. A time-sample method for measuring general activity and its components. Canad. J. Psychol., 1958, 12, 74-76. $(1,341 ; 2,343 ; 5,185 ; 6,213)$ 
Bindra, D. Motivation: a systematic reinterpretation. New York: Ronald Press, 1959. (1, 34l)

Bindra, D. Stimulus change, reactions to novelty, and response decrement. Psychol. Rev., 1959, 66, 96-103. (5, 185)

Bindra, D. Components of general activity and the analysis of behavior. Psychol. Rev., 1961, 68, 205-215. (5, 105; 6, 213)

Birch, J. Differentiation of response characteristics during multiple fixed ratio extinction. Psychol. Rep., 1964, 15, 495-502. (9, 627)

Bitterman, M. E. Behavior disorder as a function of the relative strength of antagonistic responsetendencies. Psychol. Rev., 1944, 51, 375-378. $(10,75)$

Bitterman, M. E., Feddersen, W. E., and Tyler, D. W. Secondary reinforcement and the discrimination hypothesis. Amer. J. Psychol., 1953, 66, 456-464. (5, 505; 5, 543; 8, 255)

Bitterman, M. E., Wodinsky, J., and Candland, D. K. Some comparative psychology. Amer. J. Psychol., 1958, 71, 94-110. (7, 151)

Bitterman, M. E. Toward a comparative psychology of learning. Amer. Psychologist, 1960, 15, 704712. $(6,47 ; 6,301 ; 7,151)$

Bivens, L. W. and Ray, O. S. Memory trace disruption by cortical spreading depression. Psychol. Rep., 1965, 17, 175-178. (10, 193)

Bixenstine, V. E. and Barker, Elaine. Further analysis of the determinants of avoidance behavior. J. comp. physiol. Psychol., 1964, 58, 339-343. (9, 557)

Bixenstine, V. E. Empiricism in latter-day behavioral science. Science, 1964, 145, 464-467. $(9,213)$

Black, R., Adamson, R., and Bevan, W. Runway behavior as a function of apparent intensity of shock. J. comp. physiol. Psychol., 1961, 54, 270274. $(8,269)$

Blackman, R. B. and Tukey, J. W. The measurement of power spectra. New York: Dover, 1958. $(9,619)$

Blackwell, H. R. and Schlosberg, H. Octave generalization, pitch discrimination, and loudness thresholds in the white rat. J. exp. Psychol., 1943, 33, 407-419. (9, 567)

Blair, W. C. Measurement of observing responses in human monitoring. Science, 1958, 128, 255 256. $(5,201 ; 6,431 ; 7,383 ; 9,119)$

Blandau, R. J., Boling, J. L. and Young, W. C. The length of heat in the albino rat as determined by the copulatory response. Anat. Rec., 1941, 79, 453-463. (10, 219)

Blough, D. S. Method for tracing dark adaptation in the pigeon. Science, 1955, 121, 703-704. (1, 31)

Blough, D. S. Technique for studying effects of drugs on discrimination in the pigeon. Ann.
N. Y. Acad. Sci., 1956, 65, 334-344. (1, 31; 6, $125 ; 8,445)$

Blough, D. S. Dark adaptation in the pigeon. J. comp. physiol. Psychol., 1956, 49, 425-430. $(1,31 ; 2,307)$

Blough, D. S. Effects of drugs on visually controlled behavior in pigeons. In S. Garattini and V. Ghetti (Eds.), Psychotropic drugs. Amsterdam: Elsevier, 1957. Pp. 110-118. (2, 151; 4, 281)

Blough, D. S. Some effects of drugs on visual discrimination in the pigeon. Ann. N. Y. Acad. Sci., 1957, 66, 733-739. (2, 117)

Blough, D. S. Spectral sensitivity in the pigeon. J. opt. Soc. Amer., 1957, 47, 827-833. (1, 31; $2,307 ; 4,31 ; 9,35 ; 9,351 ; 9,457 ; 9,631)$

Blough, D. S. Effect of lysergic acid diethylamide on absolute visual threshold of the pigeon. Science, 1957, 126, 304-305. (1, 31)

Blough, D. S. New test for tranquilizers. Science, 1958, 127, 586-587. (2, 219; 6, 213)

Blough, D. S. Definition and measurement in generalization research. In D. I. Mostofsky (Ed.), Stimulus generalization. Stanford: Stanford Univ. Press, 1965. Pp. 30-37. (7, 369; 9, 239)

Blough, D. S. and Millward, R. B. Learning: operant conditioning and verbal learning. Annual Rev. Psychol., 1965, 16, 63-94. (9, 581; 9, 631)

Blough, D. S. The response character of stimulus control functions. Paper read at EPA, New York, April 1966. (10, 251)

Blum, R. A. and Blum, J. S. Factual issues in the continuity controversy. Psychol. Rev., 1949, 56, 33-50. (5, 279)

Bohus, B., Endoczi, E., and Lissak, K. Correlations between avoiding conditioned reflex activity and pituitary-adrenocortical function in the rat. Acta Physiol., Hung., 1964, 24, 79-83. (10, 555)

Bohus, B. and Endoczi, E. Influence of pituitaryadrenocortical function on avoiding conditioned reflex activity in the rat. Acta Physiol., Hung., 1964, 24, 238. (10, 555)

Bohus, B. and de Wied, D. Inhibitory and facilitatory effect of two related peptides on extinction of avoidance behavior. Science, 1966, 153, 318-320. (10, 555)

Bokow, G. I. Oskoresti obrazovaniia elektrooboronitel'nykh uslovnykh refleksov u golubei. $\mathbf{Z h}$. vyssh. nerun. deialei' nosti, 1955, 5, 420-425. (2, 213)

Bolles, R. C. Grooming behavior in the rat. $J$. comp. physiol. Psychol., 1960, 53, 306-310. (6, 209)

Bolles, R. C. and Warren, J. A. The acquisition of bar press avoidance as a function of shock intensity. Psychon. Sci., 1965, 3, 297-298. (9, 553)

Bollman, J. L. A cage which limits the activity of rats. J. lab. clin. Med., 1948, 33, 1348. (9, 143)

Boneau, A. and Axelrod, S. Work decrement and 
reminiscence in pigeon operant responding. J. exp. Psychol., 1962, 64, 352-354. (9, 305)

Boneau, C. A., Holland, N. K., and Baker, W. M. Color discrimination performance of pigeons. Science, 1965, 149, 1113-1114. (10, 545)

Boren, J. J. Response rate and resistance to extinction as functions of the fixed ratio. Doctoral dissertation, Columbia, 1953. (1, 45; 1, 109; 2, $1 ; 4,87 ; 4,97 ; 4,133 ; 5,213 ; 7,159 ; 8$, 117; see also Boren, J. exp. Psychol., 1961)

Boren, J. J. and Sidman, M. Maintenance of avoidance behavior with intermittent shocks. Canad. J. Psychol., 1957, 11, 185-192. (5, 391; 6, 477; 9, 641)

Boren, J. J., Sidman, M., and Herrnstein, R. J. Avoidance, escape, and extinction as functions of shock intensity. J. comp. physiol. Psychol., $1959,52,420-425$. $(5,535 ; 8,31 ; 8,117 ; 10,451)$

Boren, J. J. and Malis, J. L. Determining thresholds of aversive brain stimulation. Amer. J. Physiol., 1961, 201, 429-433. (6, 563; 7, 69; 8, 75)

Boren, J. J. Resistance to extinction as a function of the fixed ratio. J. exp. Psychol., 1961, 61, 304-308. $(6,607 ; 9,41 ; 9,131)$

Boren, J. J. Isolation of post-shock responding in a free operant avoidance procedure. Psychol. Rep., 1961, 9, 265-266. (6, 65; 6, 477; 7, 26; 10, 461)

Boren, J. J. Stimulus probes of the fixed ratio run. Paper read at EPA, Philadelphia, April 1961. $(5,423)$

Boren, J. J. Repeated acquisitions of new behavioral chains. Amer. Psychologist, 1963, 17, 421. (Abstract) $(10,467)$

Boroczi, G., Storms, L. H., and Broen, W. E., Jr. Response suppression and recovery of responding at different deprivation levels as functions of intensity and duration of punishment. $J$. comp. physiol. Psychol., 1964, 58, 456-459. (9, 521)

Bousfield, W. A. Certain quantitative aspects of the food-behavior of cats. J. gen. Psychol., 1933, 8, 446-454. (5, 239)

Bower, G. and Miller, N. E. Rewarding and punishing effects from stimulating the same place in the rat's brain. J. comp. physiol. Psychol., 1958, 51, 669-674. (8, 75; 10, 281)

Bower, G. H., Fowler, H., and Trapold, M. A. Escape learning as a function of amount of shock reduction. J. exp. Psychol., 1959, 58, 482-484. (6, 519)

Bower, G. H. Partial and correlated reward in escape learning. J. exp. Psychol., 1960, 59, 126130. $(8,117)$

Bower, G. H. Correlated delay of reinforcement. J. comp. physiol. Psychol., 1961, 54, 196-203. $(6,163)$

Bowlby, J. The nature of the child's tie to his mother. Int. J. Psycho-anal., 1958, 39, 1-24. (9, 177)

Bowlby, J. Separation anxiety. Int. J. Psycho-anal., $1960,41,89-113 .(9,177)$

Boycott, B. B. and Young, J. Z. A memory system in Octopus vulgaris Lamark. Proc. Roy. Soc. Lond. B., 1955, 143, 449. (2, 57)

Brackbill, Yvonne. Extinction of the smiling response in infants as a function of reinforcement schedule. Child Develpm., 1958, 29, 115124. $(4,233)$

Braddock, J. C. and Braddock, J. I. Aggressive behavior among females of the Siamese fighting fish, Betta splendens. Physiol. Zool., 1955, 28, 152-172. (10, 213)

Braden, S. R. An extensive experiment in motor learning and re-learning. J. educ. Psychol., 1924, 15, 313-315. (5, 15)

Bradley, P. B. and Elkes, J. A technique for recording electrical activity of the brain in the conscious animal. EEG clin. Neurophysiol., 1953, 5, 451-456. (9, 291)

Brady, J. P. and Lind, D. L. Experimental analysis of hysterical blindness. Arch. gen. Psychiat., 1961, 4, 331-339. (8, 357)

Brady, J. P., Levitt, E. E., and Baydan, Nuran T. An operant reinforcement paradigm in the study of drug effects. Dis. nerv. System, 1962, 23, 1-6. $(9,487)$

Brady, J. V. Extinction of a conditioned fear response as a function of reinforcement schedules for the competing behavior. Arch. Psychiat., 1955, 39, 5-19. (4, 371; 7, 233)

Brady, J. V. and Hunt, H. F. Some effects of punishment and intermittent "anxiety" on a simple operant. J. comp. physiol. Psychol., 1955, 48, 305-310. (7, 247)

Brady, J. V. Extinction of a conditioned "fear" response as a function of reinforcement schedules for competing behavior. J. Psychol., 1955, 40, 25-34. (1, 265; 3, 235; 6, 507; 7, 289; 7, 405; 9, 245)

Brady, J .V. and Hunt, H. F. An experimental approach to the analysis of emotional behavior. J. Psychol., 1955, 40, 313-324. (1, 265; 2, 219; $6,507 ; 6,575 ; 9,143 ; 9,205 ; 9,487)$

Brady, J .V. A comparative approach to the evaluation of drug effects upon affective behavior. Ann. N. Y. Acad. Sci., 1956, 64, 632-643. (2, 219; 7, 293; 10, 565)

Brady, J. V. Assessment of drug effects on emotional behavior. Science, 1956, 123, 1033-1034. $(5,73 ; 10,565)$

Brady, J. V. Emotional behavior and the nervous system. Trans. N. Y. Acad. Sci., 1956, 18, 601612. (2, 43; 3, 93)

Brady, J. V. A comparative approach to the experimental analysis of emotional behavior. In $\mathbf{P}$. Hoch and J. Zubin (Eds.), Experimental psy- 
chopathology. New York: Grune \& Stratton, 1957. Pp. 20-33. (2, 43)

Brady, J. V. A review of comparative behavioral pharmacology. Ann. N.Y. Acad. Sci., 1957, 66, 719-732. (5, 105)

Brady, J. V., Boren, J. J., Conrad, D., and Sidman, $M$. The effect of food and water deprivation upon intracranial self-stimulation. J. comp. physiol. Psychol., 1957, 50, 134-137. (2, 43; 4, 213; 10, 571)

Brady, J. V. The paleocortex and behavioral motivation. In H. F. Harlow and C. N. Woolsey (Eds.), Biological and biochemical bases of behavior. Madison: Univ. Wis. Press, 1958. Pp. 193-235. $(2,43 ; 3,93)$

Brady, J. V. Temporal and emotional factors related to electrical self-stimulation of the limbic system. In $\mathbf{H}$. Jasper (Ed.), Reticular formation of the brain. Boston: Little, Brown, 1958. Pp. 689-703. (2, 43)

Brady, J. V. Ulcers in "executive" monkeys. Scientific Amer., 1958, 199, 95-100. (10, 131)

Brady, J. V. Animal experimental evaluation of drug effects upon behavior. In P. J. Braceland (Ed.), The effects of pharmacologic agents on the nervous system. Baltimore: Williams \& Wilkins, 1959. Pp. 104-125. (5, 259)

Brady, J. V. Animal experimental evaluation of drug effects upon behavior. Proc. Assn. Res. nerv. ment. Dis., 1959, 37, 104-125. (3, 35; 3, $349 ; 5,19 ; 10,95$ )

Brady, J. V. and Conrad, D. Some effects of limbic system self-stimulation upon conditioned emotional behavior. J. comp. physiol. Psychol., 1960, 53, 128-137. (8, 75)

Brady, J. V. and Thach, J. Chaining behavior and reinforcement schedule preference in the rhesus monkey. Paper read at EPA, New York, April 1960. (5, 113; 5, 543; 6, 525; 10, 281)

Brandauer, C. M. The effects of uniform probabilities of reinforcement on the response rate of the pigeon. Doctoral dissertation, Columbia, 1958. (2, 1; 2, 133; 2, 191; 3, 107; 6, 437; 6, 607; $7,125 ; 7,281 ; 9,87)$

Brash, J. C. (Ed.) Cunningham's text-book of anatomy. (9th ed.) London: Oxford Univ. Press, 1951. (9, 69)

Brecher, R. and Brecher, E. The happiest creatures on earth. Harpers, 1961, 222, 85-90. $(7,183)$

Bregman, M. and Berryman, R. Response magnitude changes in extinction. Paper read at APA, Chicago, Sept. 1956. (1, 229)

Breland, K. and Breland, Marion. A field of applied animal psychology. Amer. Psychologist, 1951, 6, 202-204. (4, 7)

Breland, K. and Breland, Marion. The misbehavior of organisms. Amer. Psychologist, 1961, 16, 681-684. (6, 73)

Brian, C. R. and Goodenough, F. C. The relative potency of color and form perception at various ages. J. exp. Psychol., 1929, 12, 197-213. $(10,375)$

Brimer, C. J. and Kamin, L. J. Disinhibition, habituation, sensitization, and the conditioned emotional response. J. comp. physiol. Psychol., 1963, 56, 508-516. $(7,405)$

Briney, S. R. and Wunder, C. C. Growth of syrian golden hamsters during continual centrifugation at 4 and 5 times earth's gravity. Amer. J. Physiol., 1926, 202, 461-464. (8, 315)

Broadbent, D. E. Some effects of noise on visual performance. Quart. J. exp. Psychol., 1954, 6, 1-5. $(1,183)$

Broadhurst, P. L. Abnormal animal behavior. In H. Eysenck (Ed.), Handbook of abnormal psychology. New York: Basic Books, 1961. Pp. 726-763. (8, 135)

Brodie, D. A., Moreno, O. M., Malis, J., and Boren, J. J. Rewarding properties of intracranial stimulation. Science, 1960, 131, 929-930. $(8,75)$

Brogden, W. J., Lipman, E. A., and Culler, E. The role of incentive in conditioning and extinction. Amer. J. Psychol., 1938, 51, 109-117. $(9,421 ; 10,131 ; 10,291)$

Brooks, L. O. Response latency in programmed learning: latency related to error rate. Doctoral dissertation, Univ. Houston, 1961. (5, 363)

Brown, J. S. A note on a temporal gradient of reinforcement. J. exp. Psychol., 1939, 25, 221227. $(6,477)$

Brown, J. S. The generalization of approach responses as a function of stimulus intensity and strength of motivation. J. comp. Psychol., 1942, 33, 209-226. (4, 371; 6, 1)

Brown, J. S. The motivation of behavior. New York: McGraw-Hill, 1961. (6, 575)

Brownstein, A. Predicting instrumental performance from the independent rates of contingent responses in a choice situation. J. exp. Psychol., 1962, 63, 29-31. (6, 81)

Bruce, H. M. and Hindle, E. The golden hamster Cricetus (mesocricetus) auratus: Waterhouse Notes on its breeding and growth. Proc. zool. Soc. (London), 1934, 2, 361-366. (10, 219)

Bruce, $H$. M. The water requirement of laboratory animals. J. animal Tech. Assn., 1950, 1, 2-8. $(2,219)$

Brush, E. S., Brush, F. R., and Solomon, R. L. Traumatic avoidance training: the effects of CS-US interval with a delayed-conditioning procedure. J. comp. physiol. Psychol., 1955, 48, 285-293. (6, 477)

Brush, F. R., Bush, R. R., Jenkins, W. O., John, W. F., and Whiting, J. W. M. Stimulus generalization after extinction and punishment: an experimental study of displacement. $J$. $a b$ norm. soc. Psychol., 1952, 47, 633-640. (2, 213; 8,89 ) 
Brush, F. R. The effects of shock intensity on the acquisition and extinction of an avoidance response in dogs. J. comp. physiol. Psychol., 1957, 50, 547-552. (9, 53)

Bryan, W. L. and Harter, N. Studies in the physiology and psychology of the telegraphic language. Psychol. Rev., 1897, 4, 27-53. (1, 1)

Bryan, W. L. and Harter, N. Studies on the telegraphic language: the acquisition of a hierarchy of habits. Psychol. Rev., 1899, 6, 345-375. $(1,1)$

Buchanan, G. N. The effects of various punishment-escape events upon subsequent choice behavior of rats. J. comp. physiol. Psychol., 1958, 51, 355-362. (5, 335)

Bugelski, R. Extinction with and without sub-goal reinforcement. J. comp. Psychol., 1938, 26, 121134. $(5,543 ; 9,41)$

Bugelski, R. The psychology of learning. New York: Holt, 1956. (1, 149; 4, 1; 5, 543)

Bullock, D. H. The inter-relationship of operant level, extinction ratio and reserve. $J$. exp. Psychol., 1950, 40, 802-804. (4, 317)

Bullock, D. H. Some aspects of human operant behavior. Psychol. Rec., 1960, 10, 241-258. (6, 431)

Bullock, D. H. and Bitterman, M. E. Probabilitymatching in the pigeon. Amer. J. Psychol., 1962, 75, 634-639. (7, 151;9, 1;9, 443)

Bullock, D. H. and Bitterman, M. E. Habit reversal in the pigeon. J. comp. physiol. Psychol., 1962, 55, 958-962. $(6,301)$

Bures, J. Reversible decortication and behavior. In M. A. B. Brazier (Ed.), The central nervous system and behavior, Trans. 2nd Conf. New York: Josiah Macy, Jr. Found., 1959. Pp. 207248. (7, 350; 10, 193)

Bures, J. and Buresova, O. The use of Leao's spreading cortical depression in research on conditioned reflexes. EEG clin. Neurophysiol., 1960, 12, 359-376. (10, 193)

Burgess, E. (Ed.) On-line computing systems. Detroit: American Data Processing, 1965. (9, 507)

Bush, R. R. and Mosteller, F. Stochastic models for learning. New York: Wiley, 1955. $(10,57)$

Butler, R. A. The responsiveness of rhesus monkeys to motion pictures. J. genet. Psychol., 1921, 28, 239-245. (10, 479)

Butler, R. A. Discrimination learning by rhesus monkeys to visual exploration motivation. $J$. comp. physiol. Psychol., 1953, 46, 95-98. (4, 119)

Butler, R. A. and Harlow, H. F. Persistence of visual exploration in monkeys. J. comp. physiol. Psychol., 1954, 47, 258-263. (4, 119)

Butler, R. A. and Alexander, H. M. Daily patterns of visual exploratory behavior in the monkey.
J. comp. physiol. Psychol., 1955, 48, 247-249. $(4,119)$

Butler, R. A. The effect of deprivation of visual incentives on visual exploration motivation in monkeys. J. comp. physiol. Psychol., 1957, 50, 177-179. (7, 381)

Butler, R. A. Investigative behavior. In A. M. Schrier, H. F. Harlow, and F. Stollnitz (Eds.), Behavior of nonhuman primates, Vol. 2. New York: Academic Press, 1965. Pp. 463-493. (10, 367)

Butter, C. M. and Thomas, D. R. Secondary reinforcement as a function of the amount of primary reinforcement. J. comp. physiol. Psychol., 1958, 51, 346-348. (5, 543)

Butter, C. M. Stimulus generalization along one and two dimensions in pigeons. J. exp. Psychol., 1963, 65, 339-346. (9, 377; 10, 17)

Byck, R. and Hearst, E. Adjustment of monkeys to five continuous days of work. Science, 1962, 138, 43. $(8,157)$

Bykov, K. M. Textbook of physiology. Moscow: Foreign Languages Pub. House, 1958. (5, 19)

Bykov, K. M. The cerebral cortex and the internal organs. (Tr. by R. Hodes) Moscow: Foreign Languages Pub. House, 1959. (8, 405)

Caldwell, D. F. and Werboff, J. Classical conditioning in newborn rats. Science, 1962, 136, 1118-1119. $(9,605)$

Cameron, N. and Magaret, Ann. Behavior pathology. New York: Houghton Mifflin, 1951. $(3,339)$

Campbell, B. A. and Sheffield, F. D. Relation of random activity to food deprivation. J. comp. physiol. Psychol., 1953, 46, 320-322. (2, 165)

Campbell, B. A. and Kraeling, D. Response strength as a function of drive level and amount of drive reduction. J. exp. Psychol., $1953,45,97-101 .(6,519 ; 8,117)$

Campbell, B. A. The fractional reduction in noxious stimulation required to produce "just noticeable" learning. J. comp. physiol. Psychol., 1955, 48, 141-148. (2, 23; 2, 227; 8, 31; 9, 357; 10, 131)

Campbell, B. A. The reinforcement difference limen (RDL) function for shock reduction. $J$. exp. Psychol., 1956, 52, 258-262. (9, 421)

Campbell, B. A. Auditory and aversion thresholds of rats for bands of noise. Science, 1957, 125, 596-597. (9, 357)

Campbell, B. A. and Teghtsoonian, R. Electrical and behavioral effects of different types of shock stimuli on the rat. J. comp. physiol. Psychol., 1958, 51, 185-192. (3, 123; 10, 291)

Campbell, B. A. and Pickleman, J. R. The imprinting object as a reinforcing stimulus. J. $\operatorname{comp}$. physiol. Psychol., 1961, 54, 592-596. (9, 177)

Campbell, B. A. and Bloom, J. M. Relative aver- 
siveness of noise and shock. J. comp. physiol. Psychol., 1965, 60, 440-442. (9, 357)

Cantor, G. N., Cantor, Joan H., and Ditrichs, R. Observing behavior of preschool children as a function of stimulus complexity. Child Develpm., 1963, 34, 683-689. (9, 119)

Capaldi, E. J. and Stanley, L. R. Temporal properties of reinforcement after-effects. $J$. exp. Psychol., 1963, 65, 169-175. (7, 135)

Carlton, P. L. and Marks, R. A. Cold exposure and heat reinforced operant behavior. Science, $1958,128,1344$. (5, 543)

Carlton, P. L. Discrimination learning. Science, 1959, 130, 1341-1343. (4, 277; 5, 481)

Carlton, P. L. and Didamo, P. Augmentation of the behavioral effects of amphetamine by atropine. J. Pharmacol. exp. Therap., 1961, 132, 9196. $(10,485)$

Carmichael, L., Hogan, H. F., and Walter, A. A. An experimental study of the effect of language on the reproduction of visually perceived form. J. exp. Psychol., 1932, 15, 73-86. $(5,375)$

Carmichael, M. and MacLean, P. D. Use of squirrel monkey for brain research with description of restraining chair. EEG clin. Neurophysiol., 1961, 13, 128-129. (6, 249)

Carpenter, C. R. Sexual behavior of free-ranging rhesus monkeys (Macaca mulatta). J. comp. physiol. Psychol., 1942, 33, 113-162. (10, 219)

Carthy, J. D. and Ebling, F. J. (Eds.) The natural history of aggression. New York: Academic Press, 1964. (10, 395)

Cartier, F. A. Comparison of overt and covert responding on a programmed lesson assigned as homework. J. program. Instruc., 1963, 2, 13-19. (8, 385)

Case, Barbara and Valenstein, E. S. Methyl methacrylate monomer, a solvent for removal of implanted electrodes. Stain Technol., 1963, 38, 201-202. (10, 290)

Catania, A. C. Concurrent performances: an analysis of ratio and interval reinforcement schedules. Amer. Psychologist, 1963, 18, 421. (Abstract) $(9,227)$

Catania, A. C. Interocular transfer of discriminations in the pigeon. Paper read at EPA, New York, April 1963. (6, 627; 7, 361; 8, 147)

Catania, A. C. and Reynolds, G. S. A quantitative analysis of the behavior maintained by interval schedules of reinforcement. Paper read at Psychon. Soc., Bryn Mawr, Oct. 1963. (10, 349; 10, 425)

Catania, A. C. and Gill, C. A. Inhibition and behavioral contrast. Psychon. Sci., 1964, 1, 257 258. $(8,263 ; 9,305 ; 9,627 ; 10,159 ; 10,243)$

Catania, A. C. Concurrent operants. In W. K. Honig (Ed.), Operant behavior: areas of research and application. New York: Appleton-
Century-Crofts, 1966. Pp. 213-270. (9, 435; 10, $367 ; 10,517)$

Chance, G. (Ed.). MIT Radiation Laboratory Series. Vol. 19. Waveforms. New York: McGraw-Hill, 1949. Pp. 166-171. (4, 85)

Chapple, E. D. Personality differences as described by invariant properties of individuals in interaction. Proc. Nat. Acad. Sci., 1940, 26, 10-16. $(2,179)$

Chapple, E. D. The interaction chronograph: its evolution and present application. Personnel, 1949, 25, 295-307. (7, 99)

Chapple, E. D., Chapple, Martha F., and Repp, Judith A. Behavioral definitions of personality and temperament characteristics. Human Organiz., 1954, 13, 34-39. (7, 99)

Chard, R. D. and Gundlach, R. H. The structure of the eye of the homing pigeon. J. comp. Psychol., 1938, 25, 249-272. (7, 361)

Chard, R. D. Visual acuity in the pigeon. J. exp. Psychol., 1939, 24, 588-608. (6, 627)

Charlesworth, W. R. and Thompson, W. R. Effect of lack of visual stimulus variation on exploratory behavior in the adult white rat. Psychol. Rep., 1957, 3, 509-512. (5, 185)

Chen, K. K. and Schmidt, C. F. The action of ephedrine, the active principle of the Chinese herb Ma Huang. J. Pharmacol. exp. Therap., 1924, 24, 339-357. (3, 293)

Chocholle, R. Variations des temps de réaction auditifs en fonction de l'intensité à diverses fréquences. Année psychol., 1940, 41, 65-124. $(7,309 ; 9,135)$

Chow, K. L. Changes of brain electropotentials during visual discrimination learning in monkeys. J. Neurophysiol., 1961, 24, 377-390. (5, 467)

Church, R. M. and Black, A. H. Latency of the conditioned heart rate as a function of the CS-US interval. J. comp. physiol. Psychol., 1958, 51, 478-482. (9, 681)

Church, R. M. Emotional reactions of rats to the pain of others. J. comp. physiol. Psychol., 1959, 52, 132-134. $(9,677)$

Church, R. M. The varied effects of punishment on behavior. Psychol. Rev., 1963, 70, 369-402. $(8,89 ; 9,53 ; 9,177 ; 10,451)$

Church, R. M. Systematic effect of random error in the yoked control design. Psychol. Bull., 1964, 62, 122-131. (8, 395)

Clark, F. C. and Steele, B. J. Some observations on the interaction of chlorpromazine and free operant avoidance bursts. Psychopharmacologia, 1963, 4, 221-231. (9, 389; 10, 485; 10, 555)

Clark, R. Behavioral effects of some time-correlated reinforcement schedules. Doctoral dissertation, Columbia, 1958. (2, 1; 2, 87)

Clark, W. A. and Molnar, C. E. The LINC: a description of the Laboratory Instrument Com- 
puter. Ann. N.Y. Acad. Sci., 1964, 115, 653-668. $(9,443 ; 9,581 ; 10,57)$

Clark, W. A. and Molnar, C. E. A description of the LINC. In R. W. Stacy and B. D. Waxman (Eds.), Computers in biomedical research. Vol. 2. New York: Academic Press, 1965. Pp. 35-66. $(9,507 ; 9,619)$

Claus, H. J. Transfer of training and reactions to novelty. Master's thesis, McGill, 1959. (2, 343)

Clayton, F. L. Secondary reinforcement as a function of reinforcement scheduling. Psychol. Rep., 1956, 2, 377-380. (5, 505; 5, 543)

Clayton, K. N. T-maze choice learning as a joint function of the reward magnitudes for the alternatives. J. comp. physiol. Psychol., 1964, 58, 333-338. $(10,417)$

Clymer, N. V. and Seifter, J. M. A method of screening sympathomimetic amines for stimulant action on the cerebrum. J. Pharmacol. exp. Therap., 1947, 89, 149-152. (9, 95)

Coate, W. B. Weakening of conditioned bar-pressing by prior extinction of its subsequent discriminated operant. J. comp. physiol. Psychol., 1956, 49, 135-138. (5, 543)

Cochran, W. G. and Cox, G. M. Experimental designs. New York: Wiley, 1950. (6, 179)

Cole, J. L. Relationship between force gradients and rate gradients in stimulus generalization. Doctoral dissertation, Duke, 1964. (8, 1; 8, 2.31)

Collier, G. Consummatory and instrumental responding as a function of deprivation. J. exp. Psychol., 1962, 64, 410-414. (7, 91)

Conant, J. B. On understanding science. New Haven: Yale Univ. Press, 1947. (9, 163)

Conger, J. J. The effects of alcohol on conflict behavior in the albino rat. Quart. J. Stud. Alcohol., 1951, 12, 1-29. (7, 293)

Conrad, G. G. and Sidman, M. Sucrose concentration as reinforcement for lever pressing by monkeys. Psychol. Rep., 1956, 2, 381-384. (1, 265; 2, 351; 6, 387)

Cook, C. and Weidley, E. Behavioral effects of some psychopharmacological agents. Ann. N.Y. Acad. Sci., 1957, 66, 740-752. (6, 213)

Cook, D. A. Message type as a parameter of learning to receive International Morse code. Paper read at EPA, New York, April 1957. $(1,1)$

Cook, L., Davidson, A., Davis, D. J., and Kelleher, R. T. Epinephrine, norepinephrine, and acetylcholine as conditioned stimuli for avoidance behavior. Science, 1960, 131, 990-991. (8, 405)

Cook, L. and Kelleher, R. T. The interaction of drugs and behavior. In E. Rothlin (Ed.), Proc. 2nd int. Congr. Neuro-psychopharmacol. Vol. 2. New York: Elsevier, 1961. Pp. 77-92. (6, 249)

Cook, L. and Kelleher, R. T. Drug effects on the behavior of animals. Ann. N.Y. Acad. Sci., 1962, 96, 315-335. (6, 249; 8, 329)
Cook, L. and Catania, A. C. Effects of drugs on avoidance and escape behavior. Fed. Proc., 1964, 23, 818-835. (8, 419; 9, 227; 9, 267; 10, 485)

Coppock, H. W. and Chambers, R. M. Reinforcement of positive preference by automatic intravenous injections of glucose. J. comp. physiol. Psychol., 1954, 47, 355-357. (5, 543)

Cornell, J. M. and Strub, H. A technique for demonstrating the inhibitory function of $S^{\Delta}$. Psychon. Sci., 1965, 3, 25-26. (9, 305; 10, 535)

Cotton, J. W. Running time as a function of amount of food deprivation. J. exp. Psychol., 1953, 46, 188-198. (5, 481)

Coughlan, R. Behavior by electronics. Life, 1963, 54, 90-106. (7, 183)

Cowan, W. M., Adamson, L., and Powell, T. P. S. An experimental study of the avian visual system. J. Anat., 1962, 95, 545-562. (9, 11)

Cowles, J. T. Food-tokens as incentives for learning by chimpanzees. Comp. Psychol. Monogr., 1937, 14, 1-96. (5, 543; 7, 83)

Cowles, J. T. Discrimination learning and pre-delay reinforcement in "delayed response." Psychol. Rev., 1941, 48, 27-30. (2, 151)

Cowles, J. T. and Pennington, L. A. An improved conditioning technique for determining auditory acuity of the rat. J. Psychol., 1943, 15, 41-47. (5, 383; 9, 605)

Crandall, L. S. The management of wild animals in captivity. Chicago: Univ. Chicago Press, 1964. $(10,219)$

Crane, J. The comparative biology of Salticid spiders at Rancho Grande, Venezuela: IV. An analysis of display. Zoologica, 1949, 34, 159. 214. $(7,45)$

Crawford, M. P. The social psychology of the vertebrates. Psychol. Bull., 1939, 36, 407-446. (10, 387)

Crespi, L. P. Quantitative variation of incentive and performance in the white rat. Amer. $J$. Psychol., 1942, 55, 467-517. (10, 417)

Crider, A., Shapiro, A., and Tursky, B. Reinforcement of spontaneous electrodermal activity. $J$. comp. physiol. Psychol., 1966, 61, 20-28. (10, 119)

Crocetti, C. P. The relation of extinction responding to drive level in the white rat. Doctoral dissertation, Columbia, 1952. (3, 71)

Cronholm, J. N. and Revusky, S. H. A sensitive rank test for comparing the effects of two treatments on a single group. Psychometrika, 1965, 30, 459-467. (10, 319)

Crowder, W. F., Morris, J. B., and McDaniel, M. $H$. Secondary reinforcement or response facilitation?: I. Resistance to extinction. J. Psychol., 1959, 48, 299-302. (5, 543; 9, 41)

Crowder, W. F., Gill, K., Jr., Hodge, C. C., and Nash, F. A., Jr. Secondary reinforcement or 
response facilitation?: II. Response acquisition. J. Psychol., 1959, 48, 303-306. (5, 543; 9, 41)

Cruze, W. W. Maturation and learning in chicks. J. comp. Psychol., 1935, 19, 371-408. (9, 95)

Culler, E., Finch, G., Girden, E., and Brogden, W. Measurements of acuity by the conditionedresponse technique. J. gen. Psychol., 1935, 12, 223-227. (5, 323)

Cumming, W. W. Stimulus disparity and variable interval reinforcement schedule as related to a behavioral measure of similarity. Doctoral dissertation, Columbia, 1955. (1, 45; 2, 1; 4, 365; $6,607 ; 10,251)$

Cumming, W. W., Siegel, I. M., and Johnson, D. F. Mirror-image reversal in pigeons. Science, $1965,149,1518$. $(9,567)$

D'Amato, M. R. Secondary reinforcement and magnitude of primary reinforcement. J. comp. physiol. Psychol., 1955, 48, 378-380. (5, 543)

D'Amato, M. R. Transfer of secondary reinforcement across the hunger and thirst drives. $J$. exp. Psychol., 1955, 49, 352-356. (6, 445)

D'Amato, M. R., Lachman, R., and Kivy, P. Secondary reinforcement as affected by reward schedule and the testing situation. J. comp. physiol. Psychol., 1958, 51, 737-741. (5, 543)

Daniel, W. J. An experimental note on the O'KellySteckle reaction. J. comp. Psychol., 1943, 35, 267-268. (5, 511)

Dardano, J. F. Relationships of intermittent noise, inter-signal interval, and skin conductance to vigilance task performance. J. appl. Psychol., 1962, 46, 106-114. (8, 207)

Davenport, J. W., Goodrich, K. P., and Hagquist, W. W. Effects of magnitude of reinforcement in Macaca Speciosa. Psychon. Sci., 1966, 4, 187188. $(10,417)$

Davenport, R. K. An investigation of the drinking behavior of the white rat. Dissert. Abstr., 1961, 21. $(10,571)$

Davis, F. C. The measurement of aggressive behavior in laboratory rats. J. genet. Psychol., 1935, 43, 213-217. (9, 233)

Davis, J. D. The reinforcing effect of weak-light onset as a function of amount of food deprivation. J. comp. physiol. Psychol., 1958, 51, 496498. $(2,165)$

Davis, J. D. and Miller, N. E. Fear and pain: their effect on self injection of amobarbital by rats. Science, 1963, 141, 1286-1287. (9, 385)

Davis, R. C. Response patterns. Trans. N.Y. Acad. Sci., 1957, 19, 731-739. (6, 477)

Davitz, J. R. and Mason, D. J. Socially facilitated reduction of a fear response in rats. J. comp. physiol. Psychol., 1955, 48, 149-151. (10, 387)

Davson, H. The physiology of the eye. (2nd ed.) Boston: Little, Brown, 1963. (7, 361)

Deadwyler, S. A. and Segal, Evalyn F. Determinants of polydipsia: VII. Removing the drinking solution midway through DRL sessions. Psychon. Sci., 1965, 3, 195-196. (9, 337)

DeBold, R. C., Miller, N. E., and Jensen, D. D. Effect of strength of drive determined by a new technique for appetitive classical conditioning of rats. J. comp. physiol. Psychol., 1965, 59, 102-108. (9, 143; 10, 291; 10, 571)

Degelman, J. Direct coupled trigger control circuit. Electronics, 1957, 30, 204-210. (4, 85)

de Groot, J. The rat forebrain in stereotaxic coordinates. Verh. Kon. Ned. Akad. Wet., B. Natuurkunde, 1959, 52, 1-40. (7, 183; 8, 75; $10,277 ; 10,517 ; 10,571)$

DeLalio, L. D. and Nunn, C. P. The dc inductive loading of contacts. Paper read at Nat. Assn. Relay Mfgrs., Stillwater, 1960. (8, 415)

Delattre, $P$. The physiological interpretation of sound spectrograms. PMLA, 1951, 66, 864-875. $(6,179)$

Delgado, J. M. R. Permanent implantation of multilead electrodes in the brain. Yale J. biol. Med., 1952, 24, 351-358. (4, 44)

Delgado, J. M. R., Roberts, W. W., and Miller, N. E. Learning motivated by electrical stimulation of the brain. Amer. J. Physiol., 1954, 179, 587-593. (2, 43)

Delgado, J. M. R. Evaluation of permanent implantation of electrodes within the brain. EEG clin. Neurophysiol., 1955, 7, 634-637. (4, 44)

de Lorge, J. O. Conditioned reinforcement: stimuli associated with the onset and offset of positive reinforcement. Doctoral dissertation, Univ. North Carolina, 1964. (10, 175; 10, 271)

Dember, W. N. and Earl, R. W. Analysis of exploratory, manipulatory, and curiosity behaviors. Psychol. Rev., 1957, 64, 91-96. (1, 341)

Demeyer, O. Determination of RC type spark quenchers for different load conditions. Paper read at Nat. Assn. Relay Mfgrs., Stillwater, 1960. (8, 415)

Denny, M. R. and King, G. F. Differential response learning on the basis of differential size of reward. J. genet. Psychol., 1955, 87, 317-320. $(10,417)$

Denny, M. R. and Adelman, H. M. Elicitation theory: I. An analysis of two typical learning situations. Psychol. Rev., 1955, 62, 290-296. (2, 81)

Desiderato, $\mathrm{O}$. Generalization of conditioned suppression. J. comp. physiol. Psychol., 1964, 57, 434-437. $(8,47)$

Deterline, W. A. An automatic device for the investigation of operant behavior in fish. Amer. J. Psychol., 1956, 69, 291-295. (3, 247; 10, 191)

Deterline, W. A. The effect of successive acquisitions and extinctions on operant discrimination learning in fish. Doctoral dissertation, Univ. Pittsburgh, 1957. (3, 247) 
de Toledo, Leyla and Black, A. H. Heart rate changes during conditioned suppression in rats. Science, 1966, 152, 1404-1406. (10, 235)

Deutsch, J. Learning and electrical self-stimulation of the brain. $J$. theoret. Biol., 1963, 4, 192-214. $(8,75)$

Deutsch, J. A. and Jones, A. D. Diluted water: an explanation of the rat's preference for saline. J. comp. physiol. Psychol., 1955, 48, 167-172. $(8,295)$

Dewhurst, W. G. and Marley, E. Quantification of behavior and cerebral electrical activity under controlled conditions. J. Physiol., 1963, 168, 1-3P. (9, 95)

Dewhurst, W. G. and Marley, E. Differential effect of sympathomimetic amines on the central nervous system. In H. Steinberg (Ed.), Animal behavior and drug action, Ciba Found. Symposium. Boston: Little, Brown, 1964. Pp. 175190. $(9,95)$

de Wied, D. Inhibition effects of ACTH and related peptides on extinction of conditioned avoidance behavior in rats. Proc. Soc. exp. Biol. Med., 1966, 122, 28-32. (10, 555)

Dews, P. B. Studies on behavior: I. Differential sensitivity to pentobarbital of pecking performance in pigeons depending on the schedule of reward. J. Pharmacol. exp. Therap., 1955, 113, 393-401. (1, 73; 1, 109; 2, 117; 2, $271 ; 3,49 ; 5,73 ; 6,125)$

Dews, P. B. Studies on behavior: II. The effects of pentobarbital, methamphetamine and scopolamine on performances in pigeons involving discriminations. J. Pharmacol. exp. Therap., 1955, 115, 380-389. (1, 87; 1, 351; 2, $107 ; 2,117 ; 2,271 ; 3,221 ; 4,351 ; 5,105 ; 8$, $329 ; 10,109)$

Dews, P. B. Modification by drugs of performance on simple schedules of positive reinforcement. Ann. N. Y. Acad. Sci., 1956, 65, 268-281. (1, 73; 1,$365 ; 2,1 ; 3,207 ; 3,293 ; 4,209 ; 5,73 ; 5$, $521 ; 6,125)$

Dews, P. B. Studies on behavior: III. Effects of scopolamine on reversal of a discriminatory performance in pigeons. J. Pharmacol. exp. Therap., 1957, 119, 343-353. (1, 73; 1, 351; 2, 107)

Dews, P. B. Analysis of effects of psychopharmacological agents in behavioral terms. Fed. Proc., 1958, 17, 1024-1030. (4, 17; 4, 351; 6, 125; 8, 427; $9,389 ; 10,485)$

Dews, P. B. and Morse, W. H. A psychopharmacology exercise for medical students. $J$. med. Educ., 1958, 33, 726-730. (6, 125)

Dews, P. B. Studies on behavior: IV. Stimulant actions of methamphetamine. J. Pharmacol. exp. Therap., 1958, 122, 137-147. (1, 359; 3, $221 ; 3,293 ; 5,73 ; 5,105 ; 5,259 ; 6,125 ; 9$, $389 ; 10,439$ )
Dews, P. B. and Morse, W. H. Behavioral pharmacology. Annual Rev. Pharmacol., 1961, 1, 145174. (5, 105; 5, 259; 6, 331; 6, 395; 10, 485)

Dews, P. B. Psychopharmacology. In A. J. Bachrach (Ed.), Experimental foundations of clinical psychology. New York: Basic Books, 1962. Pp. 423-441. $(8,45)$

Dews, P. B. A behavioral effect of amobarbital. Arch. exp. Path. Pharmak., 1964, 248, 296-307. $(8,427)$

Din, T. S. Effect of chlorpromazine on convulsions in rats and guinea pigs. Sechenov J. Physiol. USSR, 1958, 44, 1000-1006. (Trans.) (2, 213)

Dinsmoor, J. A. A quantitative comparison of the discriminative and reinforcing functions of a stimulus. J. exp. Psychol., 1950, 40, 458-472. (4, $277 ; 5,543 ; 6,75 ; 6,445 ; 10,545$ )

Dinsmoor, J. A. The effect of periodic reinforcement of bar-pressing in the presence of a discriminative stimulus. J. comp. physiol. Psychol., 1951, 44, 354-361. (3, 35; 3, 289; 4, 365; $5,41)$

Dinsmoor, J. A. The effect of hunger on discriminated responding. J. abnorm. soc. Psychol., 1952, 47, 67-72. (1, 221; 6, 343; 10, 251)

Dinsmoor, J. A. Resistance to extinction following periodic reinforcement in the presence of a discriminative stimulus. J. comp. physiol. Psychol., 1952, 45, 31-35. (5, 505; 5, 543)

Dinsmoor, J. A. A discrimination based on punishment. Quart. J. exp. Psychol., 1952, 4, 27-45. $(3,35 ; 3,123 ; 5,191 ; 7,21 ; 9,251)$

Dinsmoor, J. A. The retention of a discrimination. Science, 1952, 115, 18-19. (3, 35)

Dinsmoor, J. A., Kish, G. B., and Keller, F. S. A comparison of the effectiveness of regular and periodic secondary reinforcement. J. gen. Psychol., 1953, 48, 57-66. (5, 505; 5, 543)

Dinsmoor, J. A. Punishment: I. The avoidance hypothesis. Psychol. Rev., 1954, 61, 34-46. (6, $477 ; 7,315 ; 8,31 ; 9,267 ; 9,421 ; 9,641 ; 10$, $291 ; 10,451 ; 10,551)$

Dinsmoor, J. A. Punishment: II. An interpretation of empirical findings. Psychol Rev., 1955, 62, 96-105. (9, 267; 10, 439; 10, 451)

Dinsmoor, J. A. and Hughes, L. H. Training rats to press a bar to turn off shock. J. comp. physiol. Psychol., 1956, 49, 235-238. (2, 23; 2, $227 ; 5,391 ; 6,519 ; 8,67 ; 8,117 ; 8,171 ; 10,461)$

Dinsmoor, J. A. and Campbell, S. L. Escape-fromshock training following exposure to inescapable shock. Psychol. Rep., 1956, 2, 43-49. (2, $161 ; 10,95$ )

Dinsmoor, J. A., Hughes, L. H., and Matsuoka, Yasuko. Escape-from-shock training in a freeresponse situation. Amer. J. Psychol., 1958, 71, 325-337. (2, 23; 6, 65; 6, 75; 6, 361;8, 117;9, 655)

Dinsmoor, J. A., Matsuoka, Yasuko, and Winograd, 
E. Bar holding as a preparatory response in escape-from-shock training. J. comp. physiol. Psychol., 1958, 51, 637-639. (1, 145; 6, 65; 6, $361 ; 8,117 ; 10,461 ; 10,551)$

Dinsmoor, J. A. Studies of abnormal behavior in animals. In R. H. Waters, D. A. Rethlingshafer, and W. E. Caldwell (Eds.), Principles of comparative psychology. New York: McGraw-Hill, 1960. Pp. 289-324. (8, 135)

Dinsmoor, J. A. Operant conditioning. In J. B. Sidowski (Ed.), Experimental methods and instrumentation in psychology. New York: McGraw-Hill, 1966. Pp. 421-449. (10, 291)

Dixon, W. J. and Massey, F. J. Introduction to statistical analysis. New York: McGraw-Hill, 1951. $(9,581)$

Doehring, D. G. Color-form attitudes of deaf children. J. speech hear. Res., 1960, 3, 242-248. $(10,375)$

Doehring, D. G. and Helmer, J. E. Psychophysiological responses to variable-interval reinforcement in a human operant situation. Psychol. Rec., 1963, 13, 283-292. (9, 121)

Doehring, D. G. and Helmer, J. E. Psychophysiological responses to fixed-ratio reinforcement. Psychol. Rec., 1963, 13, 389-397. (9, 121)

Doehring, D. G., Helmer, J. E., and Fuller, E. A. Physiological responses associated with time estimation in a human operant situation. Psychol. Rec., 1964, 14, 355-362. (9, 121)

Dollard, J., Doob, L. W., Miller, N. E., Mowrer, O. H., and Sears, R. R. Frustration and aggression. New Haven: Yale Univ. Press, 1939. $(10,131)$

Doré, L. R. and Hilgard, E. R. Spaced practice and the maturation hypothesis. J. Psychol., 1937, 4, 245-261. (5, 15)

Downer, J. L. Interhemispheric integration in the visual system. In V. B. Mountcastle (Ed.), Interhemispheric relations and cerebral dominance. Baltimore: Johns Hopkins Press, 1962. Pp. 87-100. (9, 11)

Dufort, R. H. Guttman, N., and Kimble. G. A. One trial discrimination reversals in the white rat. J. comp. physiol. Psychol., 1954, 47, 248249. (3, 247)

Dvorine, I. Dvorine color perception testing charts. Baltimore: Waverly Press, 1944. (5, 375)

Dworkin, S., Katzman, J., Hutchison, G. A., and McCabe, J. R. Hearing acuity of animals as measured by conditioning methods. J. exp. Psychol., 1940, 26, 281-298. (9, 501)

Dyal, J. A. and Holland, T. A. Resistance to extinction as a function of number of reinforcements. Amer. J. Psychol., 1963, 76, 332-333. (7, 135)

Edfeldt, A. W. Silent speech and silent reading. Chicago: Univ. Chicago Press, 1960. (5, 363)
Edwards, A. L. Experimental design in psychological research. New York: Rinehart, 1950. (4, 299)

Egger, M. D. and Miller, N. E. Will rats work to escape from conflict? Amer. Psychologist, 1960, 15, 474. (Abstract) $(4,251)$

Egger, M. D. and Flynn, J. P. Effects of electrical stimulation of the amygdala on hypothalamically elicited attack behavior in cats. J. Neurophysiol., 1963, 26, 705-720. (9, 401)

Ehrenfreund, A. An experimental test of the continuity theory of discrimination learning with pattern vision. J. comp. physiol. Psychol., 1948, 41, 408-422. (1, 87; 5, 279; 6, 223)

Ehrich, W. E. and Krumbhaar, E. B. Effects of large doses of Benzedrine sulfate on the albino rat: functional and tissue changes. Ann. int. Med., 1937, 10, 1874. (3, 293)

Elam, C. B., Tyler, D. W., and Bitterman, M. E. A further study of secondary reinforcement and the discrimination hypothesis. J. comp. physiol. Psychol., 1954, 47, 381-384. (5, 543)

Ellen, P. and Powell, E. W. Temporal discrimination in rats and rhinencephalic lesions. Exp. Neurol., 1962, 6, 538-547. (7, 425)

Ellen, P. and Wilson, A. S. Perseveration in the rat following hippocampal lesions. Exp. Neurol., 1963, 8, 310-317. (7, 97)

Elliott, D. N., Stein, L., and Harrison, J. M. Determination of absolute-intensity thresholds and frequency-difference thresholds in cats. J. acoust. Soc. Amer., 1960, 32, 380-384. (5, 323; 6, 189)

Elliott, M. H. The effect of hunger on variability of performance. Amer. J. Psychol., 1934, 46, 107-112. $(5,481)$

Engel, F. L., Fredericks, Joan, Lopez, E., and Albertson, T. Some extra-adrenal actions of corticotropin on carbohydrate metabolism in the rat. Endocrinol., 1958, 63, 768-777. (10, 555)

England, S. J. M. A constant power shock source and electronic grid scrambler with an historical introduction. Percept. mot. Skills, 1964, 18, 961-975. (9, 173)

Epstein, A. N. and Teitelbaum, P. Regulation of food intake in the absence of taste, smell, and other oropharyngeal sensations. J. comp. physiol. Psychol., 1962, 55, 753-759. (10, 571)

Estes, W. K. and Skinner, B. F. Some quantitative properties of anxiety. J. exp. Psychol., 1941, 29 , 390-400. (1, 153; 1, 173; 1, 265; 2, 219; 2, $357 ; 3,35 ; 3,235 ; 3,255 ; 4,57 ; 4,371 ; 5$, $191 ; 5,353 ; 6,29 ; 6,507 ; 6,575 ; 7,247 ; 7$, $345 ; 7,381 ; 7,405 ; 8,47 ; 8,181 ; 8,279 ; 9$, $29 ; 9,143 ; 9,177 ; 9,205 ; 9,245 ; 9,487 ; 9$, $501 ; 9,663 ; 10,291 ; 10,387 ; 10,439 ; 10,565)$

Estes, W. K. Discriminative conditioning: I. A discriminative property of conditioned antici- 
pation. J. exp. Psychol., 1943, 32, 150-155. (1, $103 ; 1,303)$

Estes, W. K. An experimental study of punishment. Psychol. Monogr., 1944, 57 (3, Whole No. 263). $(1,173 ; 2,301 ; 3,123 ; 4,225 ; 5,191 ; 6,171$; $7,323 ; 9,251 ; 9,411 ; 9,487 ; 9,521 ; 10,95)$

Estes, W. K. Discriminative conditioning: II. Effects of a Pavlovian conditioned stimulus upon a subsequently established operant response. J. exp. Psychol., 1948, 38, 173-177. (1, 103; 1, $303 ; 6,445 ; 7,401 ; 9,305)$

Estes, W. K. Generalization of secondary reinforcement from the primary drive. J. comp. physiol. Psychol., 1949, 42, 286-295. (5, 543; 6, 445)

Estes, W. K. A study of the motivating conditions necessary for secondary reinforcement. J. exp. Psychol., 1949, 39, 306-310. (5, 543)

Estes, W. K. Problem of inference from curves based on group data. Psychol. Bull., 1956, 53, 134-140. (4, 133)

Estes, W. K. The statistical approach to learning theory. In S. Koch (Ed.), Psychology: a study of a science. Vol. 2. General systematic formulations, learning, and special processes. New York: McGraw-Hill, 1959. Pp. 380-491. (6, 101)

Estes, W. K. Learning theory and the new mental chemistry. Psychol. Rev., 1960, 67, 207-223. (5, 15)

Estes, W. K. Probability learning. In A. W. Melton (Ed.), Categories of human learning. New York: Academic Press, 1964. Pp. 89-128. (9, 443)

Evans, W. E., Sutherland, W. W., and Beil, R. G. The directional characteristics of delphinid sounds. In W. N. Tavolga (Ed.), Marine bioacoustics. Oxford: Pergamon Press, 1964. Pp. 353-370. $(9,535)$

Fabricius, E. and Boyd, H. Experiments on the following reactions of ducklings. Severn Wildfowl Trust Annual Rep. (Brit.), 1952-1953. Pp. 84-89. (10, 496)

Faidherbe, J., Schlag, J., and Richelle, M. Action differéntielle d'un excitant nerveux central mise en évidence par une technique de conditionnement operant chez le chat. Arch. int. Physiol. Bioehimie, 1961, 69, 52-68. (5, 521)

Falk, J. Production of polydipsia in normal rats by an intermittent food schedule. Science, 1961, 133, 195-196. (5, 61; 9, 19; 9, 37; 9, 111; 10, 199)

Falk, J. L. The behavioral regulation of waterelectrolyte balance. In M. R. Jones (Ed.), Nebraska symposium on motivation, 1961. Lincoln: Univ. Nebr. Press, 1961. Pp. 1-33. $(8,295 ; 9,19 ; 9,37 ; 9,111 ; 10,199)$

Falk, J. L. and Titlebaum, L. F. Saline solution preference in the rat: further demonstrations.
J. comp. physiol. Psychol., 1963, 56, 337-342. $(9,111)$

Falk, J. L. Studies on schedule-induced polydipsia. In M. J. Wayner (Ed.), Thirst: first international symposium on thirst in the regulation of body water. New York: Pergamon Press, 1964. Pp. 95-116. (9, 19; 9, 37; 9, 111; 10, 199)

Fant, G. Acoustic theory of speech production. The Hague: Mouton, 1960. (6, 179)

Fantino, E. J. Some data on the discriminative stimulus hypothesis of secondary reinforcement. Psychol. Rec., 1965, 15, 409-415. (10, 35)

Farmer, J. Properties of behavior under random interval reinforcement schedules. Doctoral dissertation, Columbia, 1962. $(6,607 ; 9,87)$

Farris, E. J. and Griffith, J. Q. The rat in laboratory investigation. (2nd ed.) New York: Hafner, 1949 (reprinted 1962). (9, 40)

Farris, E. J. Breeding of the rat. In E. J. Farris and J. Q. Griffith (Eds.), The rat in laboratory investigation. (2nd ed.) Philadelphia: Lippincott, 1949. Pp. 1-19. (2, 219)

Farris, H. E. Behavioral development, social organization, and conditioning of courting behavior in Japanese quail, Coturnix coturnix japonica. Doctoral dissertation, Michigan State, 1964. (10, 213)

Feldstein, S. and Jaffe, J. A note about speech disturbances and vocabulary diversity. J. Commun., 1962, 12, 166-170. (7, 99)

Feller, W. An introduction to probability theory and its applications. Vol. 1. New York: Wiley, 1950 (2nd ed., 1957). (6, 237; 6, 437; 7, 415; 8,$131 ; 10,57 ; 10,319$ )

Fenichel, $\mathrm{O}$. The psychoanalytic theory of the neuroses. New York: Norton, 1945. $(5,525)$

Ferster, C. B. The effect on extinction responding of stimuli continuously present during conditioning. J. exp. Psychol., 1951, 42, 443-449 (10, 17)

Ferster, C. B. Sustained behavior under delayed reinforcement. J. exp. Psychol., 1953, 45, 218 224. $(2,151 ; 3,221 ; 5,543 ; 6,75 ; 6,477 ; 7$, $159 ; 8,243 ; 8,439 ; 9,655 ; 9,691 ; 10,67 ; 10$, 391)

Ferster, C. B. The use of the free operant in the analysis of behavior. Psychol. Bull., 1953, 50, 263-274. (1, 45; 1, 87; 1, 123; 1, 183; 3, 259; 4,$133 ; 4,225 ; 4,365 ; 5,239 ; 6,265 ; 7,263 ; 7$, 327)

Ferster, C. B. Use of the blackout in the investigation of temporal discrimination in fixed-interval reinforcement. J. exp. Psychol., 1954, 47, 69-74. $(1,45 ; 1,87)$

Ferster, C. B. and Skinner, B. F. Schedules of reinforcement. New York: Appleton-CenturyCrofts, 1957. (More than 200 citations)

Ferster, C. B. Concurrent schedules of reinforce- 
ment in the chimpanzee. Science, 1957, 125, 1090-1091. (1, 265; 2, 65; 4, 171)

Ferster, C. B. Withdrawal of positive reinforcement as punishment. Science, 1957, 126, 509. (1, 173: 5,$391 ; 6,1 ; 6,223 ; 6,423$ )

Ferster, C. B. The control of behavior in chimpanzees and pigeons by time-out from positive reinforcement. Psychol. Monogr., 1958, 72 (8. Whole No. 461). (1, 163; 1, 167; 2, 65; 3, 143; 4,$295 ; 4,335 ; 4,383 ; 4,387 ; 5,73 ; 5,225 ; 5$, $369 ; 5,391 ; 5,543 ; 6,1 ; 6,223 ; 6,407 ; 6$, $423 ; 6,557 ; 7,405 ; 8,329 ; 9,53 ; 9,191 ; 9$, $205 ; 9,267 ; 9,487 ; 9,557 ; 10,439$ )

Ferster, C. B. Positive reinforcement and behavioral deficits of autistic children. Child Develpm., 1961, 32, 437-456. (8, 357)

Ferster, C. B. and DeMeyer, M. K. The development of performance in autistic children in an automatically controlled environment. $J$. chron. Dis., 1961, 13, 312-345. (8, 357; 9, 105)

Ferster, C. B., Levitt, E. E., Zimmerman, J. and Brady, J. P. The measurement of hypnotic effects by operant-reinforcement techniques. Psychol. Rec., 1961, 11, 427-430. (6, 589)

Ferster, C. B. and DeMeyer, M. K. A method for the experimental analysis of the behavior of autistic children. Amer. J. Orthopsychiat., 1962, 32, 89-98. (4, 84; 5, 543)

Festinger, L. Development of differential appetite in the rat. J. exp. Psychol., 1943, 32, 226-234. $(10,417)$

Finch, G. Delayed matching-from-sample and nonspatial delayed response in chimpanzees. $J$. comp. Psychol., 1942, 34, 315-319. (10, 529)

Finch, G. Chimpanzee frustration responses. Psy'chosomat. Med., 1942, 4, 233-251. (1, 83)

Findley, J. D. Rates of response in a two-member chain as a function of mean variable-interval schedule of reinforcement on the second member. Doctoral dissertation, Columbia, 1954. $(5,543 ; 7,27)$

Findley, J. D. Establishment and maintenance of long term $S^{\Delta}$ avoidance in a chimpanzee. Paper read at EPA, New York, April 1963. (8, 329)

Fine, R. Freud: a critical re-evaluation of his theories. New York: McKay, 1962. (9, 213)

Finger, F. W. The effect of food deprivation and subsequent satiation upon general activity in in the rat. J. comp. physiol. Psychol., 1951, 44, 557-564. (6, 209)

Finocchio, D. V. Toward a behavioral pharmacology of methylphenidate and methamphetamine. Paper read at Fed. Am. Soc. Exp. Biol., Atlantic City, April 1962. (9, 267)

Finocchio, D. V. Changes in temporally-spaced responding as a measure of conditioned emotional behavior. Paper read at EPA, New York, April 1963. (7, 247)

Fisher, G. L. Measured saline preference in the albino rat: the role of non-gustatory factors. Psychon. Sci., 1964, 1, 45-46. (8, 295)

Fisher, G. L. Measured sucrose preference in the albino rat: the influence of an auditory cue. Psychon. Sci., 1965, 2, 9-10. (8, 295)

Fisher, J. Interspecific aggression. In J. D. Carthy and F. J. Ebling (Eds.), The natural history of aggression. New York: Academic Press, 1964. Pp. 7-14. (10, 131)

Fjeld, H. A. The limits of learning ability in rhesus monkeys. Genet. Psychol. Monogr., 1934, 15, 369-535. (6, 271)

Flanagan, B. Goldiamond, I., and Azrin, N. Instatement of stuttering in normally fluent individuals through operant procedures. Science, 1959, 130, 979-980. $(4,197)$

Fleshler, M. and Hoffman, H. S. Stimulus generalization of conditioned suppression. Science, $1961,133,753-755 .(6,575)$

Fletcher, H. and Munson, W. A. Loudness, its definition, measurement, and calculation. $J$. acoust. Soc. Amer., 1933, 5, 82-108. (9, 135)

Ford, A. Attention-automatization: an investigation of the transitional nature of the mind. Amer. J. Psychol., 1929, 41, 1-33. (1, 183)

Ford, C. S. and Beach, F. A. Patterns of sexual behavior. New York: Harper, 1953. (8, 169)

Forgays, D. and Levin, H. Learning as a function of change of sensory stimulation in food-deprived and food-satiated animals. J. comp. physiol Psychol., 1958, 51, 50-54. (2, 165)

Forselius, S. Studies of Anabantid fishes: I. A qualitative description of the reproductive behavior in territorial species investigated under laboratory conditions with special regard to the genus Colisa: an introduction. Zool. Bidrag., 1957, 32, 93-302. $(7,45 ; 8,397)$

Fortier, C., deGroot, J., and Hartfield, J. D. Plasma free corticosteroid response to faradic stimulation in the rat. Acta endocr., Copenh., 1959, 30, 219-221. (10,555)

Fowler, H. and Trapold, M. A. Escape performance as a function of delay of reinforcement. J. exp. Psychol., 1962, 63, 464-467. (6, 519)

Fowler, H. and Miller, N. E. Facilitation and inhibition of runway performance by hind- and forepaw shock of various intensities. J. comp. physiol. Psychol., 1963, 56, 801-805. (7, 293)

Fowler, R. L. and Kimmel, H. D. Operant conditioning of the GSR. J. exp. Psychol., 1962, 63, 563-567. (10, 119)

Fox, R. E. and King, R. A. The effects of reinforcement scheduling on the strength of a secondary reinforcer. J. comp. physiol. Psychol., 1961, 54, 266-269. (5, 543)

Frankel, H. M. Effect of restraint on rats exposed to high temperature. J. appl. Physiol., 1959, 14, 997-999. (9, 143)

Fredericson, E., Story, A. W., Gurney, N. L., and 
Buttersworth, K. The relationship between heredity, sex, and aggression in two inbred mouse strains. J. genet. Psychol., 1955, 87, 121130. (7, 223)

Freeman, G. L. Changes in tension-pattern and total energy expenditure during adaptation to distracting stimuli. Amer. J. Psychol., 1939, 52, 354-360. (1, 183)

Freund, K., Diamant, J., and Pinkava, V. On the validity and reliability of the phalloplethysmographic (php) diagnosis of some sexual deviations. Rev. Czech. Med., 1958, 4, 145-151. $(8,169)$

Freund, K. Die erotische Differenzierungsfähigkeit bei an der Klinefelterschen Störung leidenden Personen. Z. Psychol., 1959, 18, 207-218. (8, 169)

Freund, K. Laboratory differential diagnosis of homo- and hetero-sexuality: an experiment with faking. Rev. Czech. Med., 1961, 7, 20-31. $(8,169)$

Freund, K. Die Homosexualität beim Mann. Leipzig: Hirzel-Verlag, 1963 (2nd ed., 1965). (8, 169)

Freund, K. A laboratory method for diagnosing predominance of homo- or hetero-erotic interest in the male. Behav. Res. Ther., 1963, 1, 85-93. (8, 169)

Frick, F. C., Keller, F. S., and Schoenfeld, W. N. Apparatus designed for introductory psychology at Columbia College. Amer. J. Psychol., 1948, 61, 409-414. (5, 457)

Frick, F. C. An analysis of an operant discrimination. J. Psychol., 1948, 26, 93-123. (1, 303; 3, $289 ; 4,365 ; 5,67 ; 6,1 ; 8,405)$

Frick, F. C. and Miller, G. A. A statistical description of operant conditioning. Amer. J. Psychol., 1951, 64, 20-36. (4, 97)

Frick, F. C. The effect of anxiety-a problem in measurement. J. comp. physiol. Psychol., 1953, 46, 120-123. $(7,91)$

Friedman, H. Wavelength generalization as a function of spacing of test stimuli. J. exp. Psychol., 1963, 65, 334-338. (9, 457)

Friedman, H. and Guttman, N. Further analysis of the various effects of discrimination training on stimulus generalization gradients. In D. I. Mostofsky (Ed.), Stimulus generalization. Stanford: Stanford Univ. Press, 1965. Pp. 255-267. $(9,305 ; 9,457 ; 9,631 ; 10,361)$

Friedman, M. H. Criteria for the selection of estrous rabbits. Endocrinol., 1938, 22, 354-359. $(10,219)$

Fries, C. C. The structure of English. New York: Harcourt, Brace \& World, 1952. $(7,99)$

Fujita, S. and Elliott, D. N. Thresholds of audition for three species of monkeys. J. acoust. Soc. Amer., 1965, 37, 139-144. (9, 135)

Furaya, Y. Grooming behavior in wild Japanese monkeys. In K. Imanisha and S. A. Altman
(Eds.), Japanese monkeys. Published by Altmann from NIH grant, 1965. Pp. 1-29. Originally published in Japanese in Primates, 1957, 1, 47-68. $(9,691)$

Furchtgott, E. and Rubin, R. D. The effect of magnitude of reward on maze learning in the white rat. J. comp. physiol. Psychol., 1953, 46, 9-12. $(10,417)$

Gagné, R. M. and Graham, C. H. The effect of an "emotional state" on the initial stages of acquisition in a conditioned operant response. Proc. Nat. Acad. Sci., 1940, 26, 297-300. (8, 261)

Gantt, W. H. and Hoffmann, W. C. Conditioned cardio-respiratory changes accompanying conditioned food reflexes. Amer. J. Physiol., 1940, 129, 360. $(6,61)$

Gantt, W. H. Cardiovascular component of the conditional reflex to pain, food, and other stimuli. Physiol. Rev., 1960, 40, 266-291. (9, 681)

Ganz, L. and Riesen, A. H. Stimulus generalization to hue in the dark-reared macaque. J. comp. physiol. Psychol., 1962, 55, 92-99. (10, 17)

Ganz, L. Hue generalization and hue discriminability in Macaca mulatta. J. exp. Psychol., 1962, 64, 142-150. (9, 351)

Garcia, J., Buchwald, N., Feder, B., and Koelling, $R$. Immediate detection of $x$-rays by the rat. Nature, 1962, 196, 1014-1015. $(9,29)$

Gardner, L. P. The responses of horses in a discriminating problem. J. comp. physiol. Psy'chol., 1937, 23, 13-36. (3, 161)

Gardner, L. P. The responses of horses to the same signal in different positions. J. comp. physiol. Psychol., 1937, 23, 304-331. (3, 161)

Gardner, R. A. Probability learning with two and three choices. Amer. J. Psychol., 1957, 70, 174185. $(6,203)$

Geller, I., Kailan, H., Stein, L., and Brady, J. F. Acquisition and extinction of conditioned "fear" as a function of partial shock reinforcement. Paper read at EPA, New York, April 1957. (7, 345)

Geller, I. The acquisition and extinction of conditioned suppression as a function of the baseline reinforcer. J. comp. physiol. Psychol., 1960, 3, 235-240. (4, 371; 7, 233)

Geller, I. and Seifter, J. The effects of meprobamate, barbiturates, $d$-amphetamine and promazine on experimentally induced conflict in the rat. Psychopharmacologia, 1960, 1, 482 492. (7, 293; 10, 439)

Geller, I. Use of approach avoidance behavior (conflict) for evaluating depressant drugs. In J. H. Nodine and J. H. Moyer (Eds.), Psychosomatic medicine. Philadelphia: Lea \& Febiger, 1962. Pp. 267-274. (10, 565)

Geller, I. and Seifter, J. The effects of monourethans, di-urethans, and barbiturates on a 
punishment discrimination. J. Pharmacol. exp. Therap., 1962, 136, 284-288. (7, 345; 10, 565)

Geller, I. Conditioned "anxiety" and punishment effects on operant behavior of goldfish (carassius auratus). Science, 1963, 141, 351-353. (7, 345)

Geller, I. Relative potencies of benzodiazepines as measured by their effects on conflict behavior. Arch. int. Pharmacodyn., 1964, 149, 243-247. (10, 565)

Gellerman, L. W. Chance orders of alternating stimuli in visual discrimination experiments. J. genet. Psychol., 1933, 42, 206-208. (5, 279; 8, 97; 8, 397; 10, 213)

General Electric Co. Transistor manual. (6th ed.) Syracuse, N.Y.: GE, 1962. $(7,150)$

General Electric Co. Silicon controlled rectifier manual. (3rd ed.) Auburn, N.Y.: GE, 1964. (8, $415 ; 10,383$ )

General Electric Co. Transistor manual. (7th ed.) Syracuse, N.Y.: GE, 1964. $(9,607 ; 10,207)$

Gentry, J. R. Immediate effects of interpolated rest periods on learning performance. Teach. Coll. Contr. Educ., 1940, No. 799. (5, 15)

Gibson, E. J. Sensory generalization with voluntary reactions. J. exp. Psychol., 1939, 24, 237-253. $(1,303)$

Gilbert, T. F. Fundamental dimensional properties of the operant. Psychol. Rev., 1958, 65, 272-282. $(2,335 ; 4,145 ; 5,89 ; 7,199)$

Gilbert, T. F. On the relevance of laboratory investigation of learning to self-instructional programming. Paper read at APA, Cincinnati, Sept. 1959. (5, 113)

Gilman, T. and Marcuse, F. L. Animal hypnosis. Psychol. Bull., 1949, 46, 151-165. (9, 63)

Ginsberg, N. Conditioned vocalization in the Budgerigar. J. comp. physiol. Psychol., 1960, 53, 183-186. (4, 171; 5, 383; 6, 197)

Glanzer, M. Stimulus satiation: an explanation of spontaneous alternation and related phenomena. Psychol. Rev., 1953, 60, 257-268. (5, 481)

Glaser, R., Klaus, D. J., and Egerman, K. Increasing team proficiency through training: II. The acquisition and extinction of a team response. Pittsburgh: Amer. Inst. Res., 1962. (7, 191)

Glaze, J. A. The association value of nonsense syllables. J. genet. Psychol., 1928, 35, 255-269. (10, 479)

Gleitman, H. and Bernheim, J. W. Retention of fixed-interval performance in rats. J. comp. physiol. Psychol., 1963, 56, 839-841. (7, 337)

Glick, D., von Redlich, Dorothy, and Levine, S. Fluorometric determination of corticosterone and cortisol in 0.02-0.05 milliliters of plasma or submilligran samples of adrenal tissue. Endocrinol., 1964, 74, 653-655. (10, 555)

Glickman, S. E. Perserverative neural processes and consolidation of the memory trace. Psychol. Bull., 1961, 58, 218-233. (9, 663)

Goffman, E. Asylums. New York: Doubleday, 1961. (8, 357)

Goin, C. J. and Goin, Olive. Introduction to herpetology. San Francisco: Freeman, 1962. $(9,671)$

Goldberg, I. A. Relations of response variability in conditioning and extinction. Doctoral dissertation, Columbia, 1959. (4, 317; 5, 481; 6, 179; 9, 69)

Goldiamond, I. Perception. In A. J. Bachrach (Ed.), Experimental foundations of clinical psychology. New York: Basic Books, 1962, Pp. 280-340. $(5,363 ; 7,269)$

Goldiamond, I. The maintenance of ongoing fluent verbal behavior and stuttering. J. Mathetics, $1962,1,57-95$. (5, 363; 5, 525)

Goldiamond, I., Atkinson, C. J., and Bilger, R. Stabilization of behavior under prolonged exposure to delayed auditory feedback. Science, 1962, 135, 437-438. (5, 363)

Goldman-Eisler, Frieda. Speech analysis and mental process. Lang. and Speech, 1958, 1, 59-75. (7, 99)

Gollin, E. S. Solution of conditional discrimination problems by young children. J. comp. physiol. Psychol., 1966, 62, 454-456. (10, 211)

Gollin, E. S. Serial learning and perceptual recognition in children: training, delay and other effects. Percept. mot. Skills, 1966, 23, 751-758. $(10,211)$

Gollub, L. R. The chaining of fixed-interval schedules. Doctoral dissertation, Harvard, 1958. (5, $113 ; 5,167 ; 5,543 ; 7,83 ; 8,243 ; 9,337 ; 9$, $475 ; 10,35 ; 10,175$ )

Gollub, L. R. Responding maintained by chained and tandem fixed-interval schedules of reinforcement. Amer. Psychologist, 1965, 20, 554. (Abstract) (10, 175)

Gonzalez, R. C., Longo, N., and Bitterman, M. E. Classical conditioning in the fish: exploratory studies of partial reinforcement. J. comp. physiol. Psychol., 1961, 54, 452-456. (7, 345)

Gonzalez, R. C., Eskin, Rochelle M., and Bitterman, M. E. Extinction in the fish after partial and consistent reinforcement with number of reinforcements equated. J. comp. physiol. Psychol., 1962, 55, 381-386. (7, 357)

Gonzalez, R. C., Eskin, Rochelle M., and Bitterman, M. E. Further experiments on partial reinforcement in the fish. Amer. J. Psychol., 1963, 76, 366-375. (7, 357)

Goodall, Jane van Lawick. New discoveries among Africa's chimpanzees. Nat. Geograph., 1965, $128,802-831$. $(9,691)$

Goodman, L. S. and Gilman, A. The pharmacological basis of therapeutics. (2nd ed.) New York: Macmillan, 1955. (1, 351; 2, 107)

Goodrich, K. P. Performance in different segments 
of an instrumental response chain as a function of reinforcement schedule. J. exp. Psy'chol., 1959, 57, 57-63. (7, 135)

Goss, A. E. Early behaviorism and verbal mediating responses. Amer. Psychologist, 1961, 16, 285-298. (6, 431)

Gottlieb, G. A naturalistic study of imprinting in wood ducklings (aix sponsa). J. comp. physiol. Psychol., 1963, 56, 86-91. (9, 177)

Gottschalk, L. A. (Ed.) Comparative psycholinguistic analysis of two psychotherapeutic interviews. New York: Int. Univ. Press, 1961. (7, 99)

Gourevitch, G., Hack, M. H., and Hawkins, J. E., Jr. Auditory thresholds in the rat measured by an operant technique. Science, 1960, 131, 10461047. (4, 149; 5, 323; 6, 189; 9, 357)

Goy, R. W. and Hunt, H. F. The resistance of an instrumental response to suppression by conditioned fear. Amer. Psychologist, 1953, 8, 509. (Abstract) (4, 371)

Graham, C. H. Behavior, perception, and the psychophysical methods. Psychol. Rev., 1950, 57, 108-120. (1, 109)

Graham, G. L. Parasitism in monkeys. Ann. N.Y. Acad. Sci., 1960, 85, 842-860. (6, 249)

Granda, A. M. and Hammack, J. T. Operant behavior during sleep. Science, 1961, 133, 14851486. (5, 391)

Grant, D. A. New statistical criteria for learning and problem solution in experiments involving repeated trials. Psychol. Bull., 1946, 43, 272-282. $(1,83)$

Grant, D. A. Additional tables of the probability of "runs" of correct responses in learning and problem-solving. Psychol. Bull., 1947, 44, 276279. $(1,83)$

Grant, D. A. Classical and operant conditioning. In A. W. Melton (Ed.), Categories of human learning. New York: Academic Press, 1964. Pp. 1-39. (9, 601)

Green, E. J. Concept formation: a problem in human operant conditioning. J. exp. Psychol., 1955, 49, 175-180. (2, 293)

Green, E. J. Stimulus variability and operant discrimination in human subjects. Amer. J. Psychol., 1956, 69, 269-273. (2, 293)

Greenbaum, H. B. Simple reaction time: a case study in signal detection. Doctoral dissertation, Columbia, 1963. $(9,135)$

Greenspoon, J. The effect of verbal and nonverbal stimuli on the frequency of members of two verbal response classes. Doctoral dissertation, Indiana, 1951. (4, 197)

Gresson, R. A. R. The effect of increased daily illumination and of reversed day and night on the oestrus cycle of the mouse (Mus musculus). Proc. Roy. Soc. Edin., 1940, 60, 333-343. (10, 219)
Grice, G. R. The relation of secondary reinforcement to delayed reward in visual discrimination learning. J. exp. Psychol., 1948, 38, 1-16. $(8,97)$

Grice, G. R. and Davis, J. D. Effect of irrelevant thirst motivation on a response learned with food reward. J. exp. Psychol., 1957, 53, 347-352. $(5,543)$

Grunzke, M. E. and Rohles, F. H., Jr. Ad lib water dispensing. Lab. primate Newsltr., 1963, $2,8$. $(8,187)$

Guhl, A. M. The behavior of chickens. In E. S. E. Hafez (Ed.), The behavior of domestic animals. Baltimore: Williams \& Wilkins, 1962. Pp. 491530. (7, 45)

Guilford, J. P. Fundamental statistics in psychology and education. (2nd ed.) New York: McGrawHill, 1956. (4, 299)

Gumley, R. H. Relay contact protection. Bell Lab. Rec., 1956, 34, 350-354. (8, 415)

Gundlach, R. H. The visual acuity of homing pigeons. J. comp. Psychol., 1933, 16, 327-342. (7, 361)

Gundlach, R. H., Chard, R. D., and Skahen, J. R. The mechanism of accommodation in pigeons. J. comp. Psychol., 1945, 38, 27-42. (7, 361)

Gurdjian, E. S. The diencephalon of the albino rat. J. comp. Neurol., 1927, 43, 1-114. (4, 213)

Guthrie, E. R. and Horton, G. P. Cats in a puzzle box. New York: Rinehart, 1946. $(4,97)$

Guthrie, E. R. Psychology of learning. New York: Harper, 1953. (2, 81; 5, 279)

Guthrie, E. R. Association by contiguity. In S. Koch (Ed.), Psychology: a study of a science. Vol. 2. General systematic formulations, learning, and special processes. New York: McGrawHill, 1959. Pp. 158-195. (9, 593)

Guttman, N. Operant conditioning, extinction, and periodic reinforcement in relation to concentration of sucrose used as reinforcing agent. J. exp. Psychol., 1953, 46, 213-224. (2, 351; 4, $125 ; 5,543 ; 10,375$ )

Guttman, N. Equal reinforcement values for sucrose and glucose solutions compared with equal sweetness values. J. comp. physiol. Psychol., 1954, 47, 358-361. (2, 351; 6, 387)

Guttman, 'N. and Kalish, H. I. Discriminability and stimulus generalization. J. exp. Psychol., 1956, 51, 79-88. (1, 303; 2, 307; 4, 31; 4, 133; 4, $157 ; 4,209 ; 5,375 ; 6,1 ; 6,237 ; 6,399 ; 7$, $21 ; 7,303 ; 8,47 ; 8,231 ; 8,279 ; 9,1 ; 9$, $239 ; 9,377 ; 10,545)$

Guttman, N. The pigeon and the spectrum and other perplexities. Psychol. Rep., 1956, 2, 449460. $(1,103 ; 4,31 ; 5,487 ; 6,1 ; 7,369)$

Guttman, N. Generalization gradients around stimuli associated with different reinforcement schedules. J. exp. Psychol., 1959, 58, 335-340. 
$(4,133 ; 4,289 ; 6,131 ; 6,171 ; 7,369 ; 9,351$; $9,457 ; 9,631 ; 10,361)$

Guttman, N. Laws of behavior and facts of perception. In S. Koch (Ed.), Psychology: a study of a science. Vol. 5. The process areas, the person. and some applied fields: their place in psychology and in science. New York: McGraw-Hill, 1963. Pp. 114-178. (7, 369)

Guttman, N. Effects of discrimination formation on generalization measured from the positive-rate baseline. In D. I. Mostofsky (Ed.), Stimulus generalization. Stanford: Stanford Univ. Press, 1965. Pp. 210-217. (9, 457; 10, 361)

Guzmán, C., Alcaraz, M., and Fernández, A. Rapid procedure to localize electrodes in experimental neurophysiology. Bol. Inst. Estud. méd. Biol. (Mex.), 1958, 16, 29-31. (10, 277)

Gwinn, G. T. The effects of punishment on acts motivated by fear. J. exp. Psychol., 1949, 39, 260-269. (10, 131)

Gynther, M. D. Differential eyelid conditioning as a function of stimulus similarity and strength of response to the CS. J. exp. Psychol., 1957, 53, 408-416. (7, 233)

Haber, A. and Kalish, H. I. Prediction of discrimination from generalization after variations in schedule of reinforcement. Science, 1963, 142, 412-413. (7, 369)

Hafez, E. S. E. The behavior of domestic animals. Baltimore: Williams \& Wilkins, 1962. (9, 177: 10, 219)

Haggard, D. F. Acquisition of a simple running response as a function of partial and continuous schedules of reinforcement. Psychol. Rec., 1959, 9, 11-18. $(7,135)$

Haggard, E. A. and Thompson, W. R. Electrodes for measuring the GSR in small animals. Amer. J. Psychol., 1954, 67, 357-358. (9, 605)

Halasz, M. F. Extinction óf intercurrent avoidance and repetitive responses under chlorpromazine. Doctoral dissertation, Univ. Chicago, 1959. (4, 287)

Hall, C. S. and Klein, S. J. Individual differences in aggressiveness in rats. J. comp. Psychol., 1942, 33, 371-383. (9, 233)

Hall, C. S. and Whiteman, P. H. The effects of infantile stimulation upon later emotional stability in the mouse. J. comp. physiol. Psy'chol., 1952, 45, 307-312. (2, 335)

Hall, J. F. Studies in secondary reinforcement: I. Secondary reinforcement as a function of the frequency of primary reinforcement. J. $\operatorname{comp}$. physiol. Psychol., 1951, 44, 246-251. (5, 543)

Hall, J. F. Studies in secondary reinforcement: II. Secondary reinforcement as a function of the strength of drive during primary reinforcement. J. comp. physiol. Psychol., 1951, 44, 462466. $(5,543)$
Hall, J. F. and Hanford, P. V. Activity as a function of restricted feeding schedule. J. comp. physiol. Psychol., 1954, 47, 362-363. (6, 209)

Hall, J. F. The relationship between external stimulation, food deprivation, and activity. $J$. comp. physiol. Psychol., 1956, 49, 339-341. (5, 89)

Hall, K. R. L. Aggression in monkey and ape societies. In J. D. Carthy and F. J. Ebling (Eds.), The natural history of aggression. New York: Academic Press, 1964. Pp. 51-64. (10, 131)

Hall, R. D. and Kling, J. W. Amount of consummatory activity and performance in a modified T-maze. J. comp. physiol. Psychol., 1960, 53, 165-168. $(4,125)$

Halstead, W. and Yacorzynski, G. A jumping method for establishing differential responses in pigeons. $J$. genet. Psychol., 1938, 52, 227-231. (7, 361)

Hamilton, C. L. Effects of LSD-25 and amphetamine on a running response in the rat. $A$ mer. Med. Assn. Arch., 1960, 2, 104-109. (6, 213)

Hamilton, W. F. and Coleman, T. B. Trichromatic vision in the pigeon as illustrated by the spectral hue discrimination curve. J. $\operatorname{comp}$. Psychol., 1933, 15, 183-191. (4, 31)

Hamilton, W. F. and Goldstein, J. L. Visual acuity and accommodation in the pigeon. J. comp. Psychol., 1933, 15, 193-197. (7, 361)

Hamming, R. W. Numerical methods for scientists and engineers. New York: McGraw-Hill, 1962. $(9,619)$

Hammond, J. and Marshall, F. H. A. Reproduction in the rabbit. Edinburgh: Oliver \& Boyd, 1925. $(10,219)$

Hanson, H. M. Discrimination training effect on stimulus generalization gradient for spectrum stimuli. Science, 1957, 125, 888-889. (1, 303; 2, $319 ; 3,9 ; 4,157 ; 4,237 ; 10,17)$

Hanson, H. M. Effects of discrimination training on stimulus generalization. J. exp. Psychol., 1959, 58, 321-334. (3, 143; 3, 313; 4, 31; 4, 57; 4,$133 ; 4,157 ; 4,209 ; 4,237 ; 4,289 ; 5,19 ; 5$, $67 ; 5,191 ; 5,435 ; 6,1 ; 6,171 ; 6,343 ; 7$, $217 ; 7,233 ; 7,303 ; 9,1 ; 9,155 ; 9,239 ; 9$, $351 ; 9,457 ; 9,613 ; 9,631 ; 10,361$ )

Hanson, H. M. Stimulus generalization following three-stimulus discrimination training. $J$. comp. physiol. Psychol., 1961, 54, 181-185. (6, $171 ; 7,21 ; 7,217$ )

Hanson, H. M. and Stone, C. A. Animal techniques for evaluating antianxiety drugs. In J. H. Nodine and P. E. Siegler (Eds.), Animal and clinical pharmacologic techniques in drug evaluation. Chicago: Year Book Med. Pub., 1964. Pp. 317-324. (10, 565)

Hanson, L. F. Light avoidance and light aversion in the albino rat as a function of intensity of 
illumination. Doctoral dissertation, Columbia, 1951. $(8,321)$

Haralson, J. Effect of drive on latency and rate of operant responding at different levels of training in rat and fish. J. comp. physiol. Psychol., 1964, 58, 321-323. (9, 153)

Haralson, J., Gillman, C., and Ralph, G. Interaction between effort and partial reinforcement in free operant response of rats and fish. Psychol. Rep., 1965, 16, 761-768. (9, 153)

Haralson, J. V. and Bitterman, M. E. A leverdepression apparatus for the study of learning in fish. Amer. J. Psychol., 1950, 63, 250-256. (3, 161)

Hargreaves, W. A. An investigation of time patterns in spontaneous conversations. Master's thesis, Univ. Chicago, 1955. (2, 179)

Hargreaves, W. A. A model for speech unit duration. Lang. and Speech, 1960, 3, 164-173. (7, 99)

Hargreaves, W. A. and Starkweather, J. A. Vocal behavior: an illustrative case study. Paper read at WPA, Seattle, June 1961. $(7,99)$

Harlow, H. F. Social facilitation of feeding in the albino rat. J. genet. Psychol., 1932, 41, 211-221. $(10,387)$

Harlow, H. F. and Yudin, H. C. Social behavior of primates: I. Social facilitation of feeding in the monkey and its relation to attitudes of ascendance and submission. J. comp. Psychol., 1933, 16, 171-185. (10, 387)

Harlow, H. F. The formation of learning sets. Psychol. Rev., 1949, 56, 51-65. (2, 335; 5, 279)

Harlow, H. F. Analysis of discrimination learning by monkeys. J. exp. Psychol., 1950, 40, 26-39. $(2,335 ; 10,3)$

Harlow, H. F. and Zimmermann, R. R. The development of affectional responses in infant monkeys. Proc. Amer. Phil. Soc., 1958, 102, 501509. $(9,177)$

Harlow, H. F. Learning set and error factor theory. In S. Koch (Ed.), Psychology: a study of a science. Vol. 2. General systematic formulations, learning, and special processes. New York: McGraw-Hill, 1959. Pp. 492-537. (4, 281; 10,$3 ; 10,467$ )

Harlow, H. F. and Zimmermann, R. R. Affectional responses in the infant monkey. Science, 1959, 130, 421-432. (9, 177; 10, 387)

Harmon, F. L. The effects of noise upon certain psychological and physiological processes. Arch. Psychol., N. Y., 1933, 23 (No. 147), 1-81. $(1,183)$

Harris, P. and Nygaard, J. E. Resistance to extinction and number of reinforcements. Psychol. Rep., 1961, 8, 233-234. (7, 135)

Harris, S. C., Ivy, A. C., and Searle, L. M. The mechanism of amphetamine-induced loss of weight. J.A.M.A., 1947, 134, 1468-1475. $(3,293)$
Harrison, J. M. and Tracy, W. H. The use of auditory stimuli to maintain lever-pressing behavior. Science, 1955, 121, 373-374. (2, 23; 9, 357)

Harrison, J. M. Some behavioral functions of the lower auditory pathways in the rat. J. comp. Neurol., 1960, 115, 143-153. (3, 207)

Hart, B. I. Significance levels for the ratio of the mean square successive difference to the variance. Ann. math. Statist., 1942, 13, 445-447. $(10,555)$

Harwood, C. T. and Mason, J. W. A systematic evaluation of the Nelson-Samuels plasma 17hydroxycorticosteroid method. J. clin. Endocrinol., 1956, 16, 790. (5, 353)

Harwood, C. T. and Mason, J. W. Acute effects of tranquilizing drugs on the anterior pituitaryACTH mechanism. Endocrinol., 1957, 60, 239246. $(5,353)$

Hauschild, F. Tierexperimentelles über eine peroral wirksame zentralanaleptische Substanz mit peripherer Kreislaufwirkung. Klin. Wchnschr., 1938, 17, 1257-1258. (3, 293)

Hayes, K. J. Cognitive and emotional effects of electroconvulsive shock in rats. J. comp. physiol. Psychol., 1948, 41, 40-61. (9, 663)

Hayes, K. J. and Pereboom, A. C. Artifacts in criterion-reference learning curves. Psychol. Rev., 1959, 66, 23-26. (3, 71)

Hays, W. L. Statistics for psychologists. New York: Holt, Rinehart \& Winston, 1963. (8, 347; 9, 443)

Heape, W. Ovulation and degeneration of ova in the rabbit. Proc. Roy. Soc. Lond. B., 1905, 76, 260-268. (10, 219)

Hearst, E. The behavioral effects of some temporally defined schedules of reinforcement. Doctoral dissertation, Columbia, 1956. (1, 45; 1, 245; 2, 191)

Hearst, E., Beer, B., Sheatz, G., and Galambos, R. Some electrophysiological correlates of conditioning in the monkey. EEG clin. Neurophysiol., 1960, 12, 137-152. (4, 309; 5, 19; 5, $467 ; 6,61$ )

Hearst, E. Simultaneous generalization gradients for appetitive and aversive behavior. Science, 1960, 132, 1769-1770. (5, 19; 7, 369; 8, 269; 9, 267)

Hearst, E. and Whalen, R. E. Facilitating effects of $d$-amphetamine on discriminated-avoidance performance. J. comp. physiol. Psychol., 1963, 56, 124-128. (9, 389; 10, 485)

Hearst, E. Escape from a stimulus associated with both reward and punishment. J. comp. physiol. Psychol., 1963, 56, 1027-1031: (8, 31; 9, 267; 10, 75)

Hearst, E. and Koresko, Minnie B. Self-presentation and self-termination of a conflict-produc- 
ing stimulus. Science, 1964, 146, 415-416. (10, 75)

Hearst, E. Approach, avoidance, and stimulus generalization. In D. I. Mostofsky (Ed.), Stimulus generalization. Stanford: Stanford Univ. Press, 1965. Pp. 331-355. (7, 369; 8, 9; 8, 269)

Hearst, E. and Poppen, R. Steepened generalization gradients after massed extinction to the CS. Psychon. Sci., 1965, 2, 83-84. (9, 457; 9, 631)

Hebb, D. O. The organization of behavior. New York: Wiley, 1949. (9, 251)

Hecht, S. and Verrijp, C. D. Intermittent stimulation by light: III. The relation between intensity and critical fusion frequency for different retinal locations. J. gen. Physiol., 1933, 17, 251-268. $(9,501)$

Hediger, H. Wild animals in captivity. London: Butterworths, 1950. (2, 288)

Hedner, P. and Rerup, C. Plasma corticosteroid levels and adrenal ascorbic acid after intravenous corticotrophin injections and "stressful" stimuli in the rat. Acta endocr., Copenh., 1962, 39, 527-538. (10, 555)

Hefferline, R. F. An experimental study of avoidance. Genet. Psychol. Monogr., 1950, 42, 213334. $(2,23 ; 3,207 ; 4,317 ; 5,41 ; 5,391 ; 6,361$; $8,9 ; 8,31)$

Hefferline, R. F. The role of proprioception in the control of behavior. Trans. N. Y. Acad. Sci., 1958, 20, 739-764. (4, 41; 9, 69)

Hefferline, R. F., Keenan, B., and Harford, R. A. Escape and avoidance conditioning in human subjects without their observation of the response. Science, 1959, 130, 1338-1339. (3, 155; 4,$41 ; 6,307 ; 6,361 ; 9,69 ; 9,557$ )

Hefferline, R. F., Keenan, B., Harford, R. A., and Birch, J. Electronics in psychology. Columbia Engng. Quart., 1960, 13, 10-15. (4, 41)

Hefferline, R. F. Learning theory and clinical psychology-an eventful symbiosis? In A. J. Bachrach (Ed.), Experimental foundations of clinical psychology. New York: Basic Books, 1962. Pp. 97-138. (6, 307; 6, 431)

Hefferline, R. F. and Perera, T. B. Proprioceptive discrimination of a covert operant without its observation by the subject. Science, 1963, 139, 834-835. (6, 307)

Hegge, F. W., Pierrel, Rosemary, Sherman, J. G., and Sadowsky, S. Non-differential conditioning and extinction of operant responding across a sound intensity continuum. Psychon. Sci., 1965, 2, 11-12. (9, 219)

Heid, Nancy L. The effect of levels of percentage reinforcement on a chained response baseline with retardates. Master's thesis, Univ. Washington, 1963. $(7,199)$

Heise, G. A. Auditory thresholds in the pigeon. Amer. J. Psychol., 1953, 66, 1-19. (9, 501)

Heise, G. A. and Boff, E. Continuous avoidance as a base-line for measuring behavioral effects of drugs. Psychopharmacologia, 1962, 3, 264-282. $(9,163)$

Helson, H. Adaptation level theory. In S. Koch (Ed.), Psychology: a study of a science. Vol. 1. Sensory, perceptual, and physiological foundations. New York: McGraw-Hill, 1959. Pp. 565. 621. $(8,269)$

Hendry, D. P. The effect of correlated amount of reward on performance on a fixed-interval schedule of reinforcement. J. comp. physiol. Psychol., 1962, 55, 387-391. (7, 207; 10, 417)

Herbert, M. J. and Arnold, W. J. A reaction chaining apparatus. J. comp. physiol. Psychol., 1947, 40, 227-229. (6, 477)

Herr, F., Stewart, Jane, and Charest, Marie-Paule. Tranquilizers and antidepressants: a pharmacological comparison. Arch. int. Pharmacodyn., 1961, 134, 328-342. (6, 213)

Herrick, R. M., Myers, J. L., and Korotkin, A. L. Changes in $S^{D}$ and in $S^{\Delta}$ rates during the development of an operant discrimination. $J$. comp. physiol. Psychol., 1959, 52, 359-363. (3, $35 ; 4,57 ; 4,335 ; 7,139 ; 8,269$ )

Herrick, R. M. Lever displacement during a discrimination-differentiation. J. comp. physiol. Psychol., 1964, 57, 139-146. (7, 211)

Herrnstein, R. J. Behavioral consequences of the removal of a discriminative stimulus associated with variable-interval reinforcement. Doctoral dissertation, Harvard, 1955. (3, 143; 4, 179; 4, $267 ; 4,383 ; 5,73 ; 6,1 ; 6,253 ; 6,407 ; 6$, $607 ; 9,205 ; 9,267 ; 9,487$ )

Herrnstein, R. J. and Morse, W. H. A technique for studying the preferability of schedules of intermittent reinforcement. Paper read at EPA, Philadelphia, April 1955. (3, 143; 6, 525)

Herrnstein, R. J. and Morse, W. H. Selective action of pentobarbital on component behaviors of a reinforcement schedule. Science, 1956, 124, 367-368. (1, 109; 2, 117; 6, 125)

Herrnstein, R. J. and Morse, W. H. Some effects of response-independent positive reinforcement on maintained operant behavior. J. comp. physiol. Psychol., 1957, 50, 461-467. (1, 15; 1, $73 ; 1,235 ; 4,57 ; 4,383 ; 6,29 ; 7,405)$

Herrnstein, R. J. and Morse, W. H. Effects of pentobarbital on intermittently reinforced behavior. Science, 1957, 125, 929-931. (1, 351; 3, $193 ; 4,343 ; 7,337 ; 9,267$ )

Herrnstein, R. J. and Sidman, M. Avoidance conditioning as a factor in the effects of unavoidable shocks on food-reinforced behavior. $J$. comp. physiol. Psychol., 1958, 51, 380-385. $(1,265 ; 6,29 ; 6,507)$

Herrnstein, R. J. Some factors influencing behavior in a two-response situation. Trans. N. Y. Acad. Sci., 1958, 21, 35-45. (2, 65; 4, 263; 4, 267; 5, $113 ; .5,279 ; 6,53 ; 7,1 ; 8,305 ; 9,443 ; 10,57)$ 
Herrnstein, R. J. Stereotypy and intermittent reinforcement. Science, 1961, 133, 2067-2069. (5, $105 ; 5,299 ; 5,481 ; 7,351)$

Herrnstein, R. J. and van Sommers, P. Method for sensory scaling with animals. Science, 1962 , 135, 40-41. (7, 303)

Hess, E. H. Imprinting in birds. Science, 1964, 146, 1128-1139. (9, 177; 10, 495)

Hess, W. R. Stammganglien-Reizversuche. Ber. ges. Physiol., 1928, 42, 554. (9, 401)

Hess, W. R. and Brugger, M. Das subcorticale Zentrum der affektiven Abwehrreaktion. Helv. Physiol. Acta, 1943, 1, 33-53. (9, 401)

Hickson, R. H. Response probability in a twochoice learning situation with varying probability of reinforcement. J. exp. Psychol., 1961, 62, 138-144. (7, 151)

Hilgard, E. R. and Marquis, D. G. Conditioned eyelid responses in monkeys with a comparison of dog, monkey, and man. Psychol. Monogr., 1936, 47 (2, Whole No. 212). (9, 601)

Hilgard, E. R. and Marquis, D. G. Conditioning and learning. New York: Appleton-CenturyCrofts, 1940. (5, 391; 5, 543; 9, 475)

Hilgard, E. R. Methods and procedures in the study of learning. In S. S. Stevens (Ed.), Handbook of experimental psychology. New York: Wiley, 1951. Pp. 517-567. (9, 515)

Hilgard, E. R. Theories of learning. (2nd ed.) New York: Appleton-Century-Crofts, 1956. (8, 269)

Hill, J. H. and Stellar, E. An electronic drinkometer. Science, 1951, 114, 43-44. (2, 289; 10, 571)

Hill, L. W. Relay contact protection for dc applications. Paper read at Nat. Assn. Relay Mfgrs., Stillwater, 1958. (8, 415)

Hill, W. F. Activity as an autonomous drive. $J$. comp. physiol. Psychol., 1956, 49, 15-19. (5, 89)

Hill, W. F. The effect of long confinement on voluntary wheel-running by rats. J. comp. physiol. Psychol., 1958, 51, 770-773. (2, 127)

Hind, J. E., Goldberg, J. M., Greenwood, D. D., and Rose, J. E. Some discharge characteristics of single neurons in the inferior colliculus of the cat: II. Timing of the discharges and observations on binaural stimulation. J. Neurophysiol., 1963, 26, 321-341. (9, 135)

Hinde, R. A. Animal Behavior. New York: McGraw-Hill, 1966. (10, 395)

Hiss, R. H. A comparison of two methods for obtaining wavelength generalization gradients. Master's thesis, Kent State, 1962. (6, 171)

Hiss, R. H. and Thomas, D. R. Stimulus generalization as a function of testing procedure and response measure. J. exp. Psychol., 1963, 65, 587-592. (7, 369; 9, 239; 9, 457)

Hodges, J. R. and Jones, M. T. The effect of injected corticosterone on the release of adrenocorticotrophic hormone in rats exposed to acute stress. J. Physiol., 1963, 167, 30-37. (10, 555)

Hodos, W. and Valenstein, E. S. Motivational variables affecting the rate of behavior maintained by intracranial stimulation. J. comp. physiol. Psychol., 1960, 53, 502-508. (10, 571)

Hodos, W. Progressive ratio as a measure of reward strength. Science, 1961, 134, 943-944. (6, 387; 6,$525 ; 7,51 ; 10,503$ )

Hodos, W. and Valenstein, E. S. An evaluation of response rate as a measure of rewarding intracranial stimulation. J. comp. physiol. Psychol.. $1962,55,80-84$. $(6,387 ; 7,285 ; 8,75)$

Hodos, W. The nonaversive properties of long durations of rewarding brain stimulation. Amer. Psychologist, 1963, 18, 437. (8, 75)

Hodos, W. Motivational properties of long duration of rewarding brain stimulation. J. comp. physiol. Psychol., 1965, 59, 219-224. (10, 281: 10, 515)

Hodos, W. and Karten, H. J. Brightness and pattern discrimination deficits in the pigeon after lesions of nucleus rotundus. Exp. brain Res., 1966, 2, 151-167. (10, 529)

Hoebel, B. G. and Teitelbaum, P. Hypothalamic control of feeding and self-stimulation. Science, 1962, 135, 375-377. (10, 571)

Hoel, P. G. Introduction to mathematical statistics. New York: Wiley, 1954. (1, 303)

Hoffman, H. S., Fleshler, M., and Jensen, P. K. Aversive training: long-term effects. Science, 1962, 138, 1269-1270. $(7,21)$

Hoffman, H. S. The analysis of discriminated avoidance. In W. K. Honig (Ed.), Operant behavior: ureas of research and application. New York: Appleton-Century-Crofts, 1966. Pp. 499-530. (10, 131)

Hofsteater, H. T. An experiment in preschool education. Gallaudet Coll. Bull., 1959, 8, 1-17. $(5,363)$

Hogenson, Marilyn J. Food satiation in the pigeon. Honors thesis, Mt. Holyoke, 1960. (5, 239)

Holland, A. L. and Matthews, J. Application of teaching-machine concepts to speech pathology and audiology. Asha, 1963, 5, 474-482. (10, 3)

Holland, J. G. Technique for behavioral analysis of human observing. Science, 1957, 125, 348350. (1, 179; 1, 183; 2, 133; 2, 203; 3, 27; 3, 111; 3,$183 ; 3,339 ; 5,201 ; 5,363 ; 6,179 ; 6,431 ; 9$, $119 ; 9,121 ; 10,395)$

Holland, J. G. Human vigilance. Science, 1958, 128, 61-67. (1, 179; 1, 359; 3, 27; 3, 183; 3, 275; 3, $339 ; 4,87 ; 5,201 ; 5,363 ; 6,149 ; 6,431 ; 7$, $79 ; 7,333 ; 7,383 ; 8,207 ; 8,357 ; 9,119$ )

Holland, J. G. and Skinner, B. F. The analysis of behavior: a program for self-instruction. New York: McGraw-Hill, 1961. (4, 305; 8, 31; 8,$279 ; 9,191$ )

Holland, J. G. New directions in teaching machine 
research. In J. E. Coulson (Ed.), Programmed learning and computer-based instruction. New York: Wiley, 1961. Pp. 46-57. (10, 3; 10, 261)

Holland, J. G. Research on programming variables. In R. Glaser (Ed.), Teaching machines and programmed learning: II. Data and directions. Washington, D.C.: Nat. Educ. Assn., 1965. Pp. 66-117. $(10,3 ; 10,261)$

Holz, W. C. and Azrin, N. H. Recovery during punishment by intense noise. Psychol. Rep., 1962, 11, 655-657. (6, 407; 9, 205)

Homme, L. E. and Glaser, R. Relationships between programmed textbook and teaching machines. In E. Galanter (Ed.), Automatic teaching. New York: Wiley, 1959. Pp. 103-107. $(3,275)$

Honig, W. K. Prediction of preference, transposition, and transposition reversal from the generalization gradient. Doctoral dissertation, Duke, 1958. (4, 31; 6, 171; see also Honig. J. exp. Psychol., 1962)

Honig, W. K., Thomas, D. R., and Guttman, N. Differential effects of continuous extinction and discrimination training on the generalization gradient. J. exp. Psychol., 1959, 58, 145152. $(3,9 ; 4,157 ; 4,237 ; 4,289 ; 5,435 ; 6,171$; $7,233 ; 9,457 ; 9,631 ; 10,361)$

Honig, W. K. Generalization of extinction on the spectral continuum. Psychol. Rec., 1961, 11, 269-278. (5, 435; 7, 21; 8, 47; 9, 377)

Honig, W. K. Prediction of preference, transposition, and transposition-reversal from the generalization gradient. J. exp. Psychol., 1962, 64, 239-248. (7, 21; 8, 263; 9, 457; 10, 361)

Honig, W. K. and Day, Roberta W. Discrimination and generalization on a dimension of stimulus difference. Science, 1962, 138, 29-31. (7, 199; 7, 303)

Honig, W. K., Boneau, C. A., Burstein, K. R., and Pennypacker, H. S. Pósitive and negative generalization gradients obtained after equivalent training conditions. J. comp. physiol. Psychol., 1963, 56, 111-116. (7, 21; 9, 11; 9, 305; 9, 567; 10, 361)

Honig, W. K. Discrimination, generalization and transfer of the basis of stimulus differences. In D. I. Mostofsky (Ed.), Stimulus generalization. Stanford: Stanford Univ. Press, 1965. Pp. 218254. $(9,351)$

Honzik, C. H. Delayed reaction in rats. Univ. Calif. Publ. Psychol., 1931, 4, 307-318. (10, 529)

Hopkins, C. O. Effectiveness of secondary reinforcing stimuli as a function of the quantity and quality of food reinforcement. J. exp. Psychol., 1955, 50, 339-342. $(5,543)$

Horner, J. L., Longo, N., and Bitterman, M. E. A shuttle box for fish and a control circuit of general applicability. Amer. J. Psychol., 1961, 74, 114-120. (6, 47)
House, Betty J. and Zeaman, D. Transfer of a discrimination from objects to patterns. J. exp. Psychol., 1960, 59, 298-302. (10, 3)

House, Betty J. and Zeaman, D. Miniature experiments in the discrimination learning of retardates. In L. P. Lipsitt and C. C. Spiker (Eds.), Advances in child development and behavior. Vol. 1. New York: Academic Press, 1963. Pp. 313-374. (7, 205)

Hovey, H. B. Effects of general distraction on the higher thought processes. Amer. J. Psychol., $1928,40,585-591$. (1, 183)

Hovland, C. I. The generalization of conditioned responses: $I$. The sensory generalization of conditioned responses with varying frequencies of tone. J. gen. Psychol., 1937, 17, 125-148. (1, $303 ; 4,289 ; 4,371 ; 6,1 ; 8,279$ )

Hovland, C. I. The generalization of conditioned responses: II. The sensory generalization of conditioned responses with varying intensities of tone. J. genet. Psychol., 1937, 51, 279-291. $(1,303 ; 6,1 ; 6,343 ; 8,47)$

Hovland, C. I. The generalization of conditioned responses: III. Extinction, spontaneous recovery and disinhibition of conditioned and of generalized responses. J. exp. Psychol., 1937, 21, 47-62. (4, 371)

Hovland, C. I. The generalization of conditioned responses: IV. The effects of varying amounts of reinforcement upon the degree of generalization of conditioned responses. J. exp. Psychol., 1937, 21, 261-276. (4, 371; 6, 1)

Hovland, C. I. A "communication analysis" of concept learning. Psychol. Rev., 1952, 59, 461472. $(3,275)$

Hovland, C. I. A set of flower designs for experiments in concept formation. Amer. J. Psychol.. 1953, 66, 140-142. $(3,275)$

Hug, O. Reflex-like responses of lower animals and mammalian organs to ionizing radiation. Int. J. rad. Biol., 1960 (Spec. Suppl. 2), 217-226. $(9,29)$

Hughes, B. and Schlosberg, H. Conditioning in the white rat: IV. The conditioned eyelid reflex. J. exp. Psychol., 1938, 23, 641-650. (9, 605)

Hughes, L. H. Delay of shock-escape reinforcement. Doctoral dissertation, Indiana, 1959. $(6,75)$

Hughes, R. L. and Myers, K. Behavioral cycles during pseudopregnancy in confined populations of domestic rabbits and their relation to the histology of the female reproductive tract. Aust. J. Zool., 1966, 14, 173-183. (10, 219)

Hull, C. L. A functional interpretation of the conditioned reflex. Psychol. Rev., 1929, 36, 498-511. $(9,421)$

Hull, C. L. The goal gradient hypothesis and maze learning. Psychol. Rev., 1932, 39, 25-43. (5, 369)

Hull, C. L. Principles of behavior. New York: Appleton Century, 1943. (1, 149; 2, 307; 2, 357: 
4,$133 ; 5,481 ; 5,543 ; 6,343 ; 8,1 ; 8,107 ; 8$, $439 ; 9,649 ; 10,67$ )

Hull, C. L. The problem of primary stimulus generalization. Psychol. Rev., 1947, 54, 120-134. $(1,303)$

Hull, C. L. Stimulus intensity dynamism (V) and stimulus generalization. Psychol. Rev., 1949, 56, 67-76. (9, 219)

Hull, C. L. Simple qualitative discrimination learning. Psychol. Rev., 1950, 57, 303-313. (5, 279; 6,$1 ; 6,223$ )

Hull, C. L. Essentials of behavior. New Haven: Yale Univ. Press, 1951. (1, 303; 8, 47)

Hull, C. L., Livingston, J. R., Rouse, R. O., and Barker, A. N. True, sham, and esophageal feeding as reinforcements. J. comp. physiol. Psychol., 1951, 44, 236-245. (5, 543)

Hull, C. L. A behavior system. New Haven: Yale Univ. Press, 1952. (2, 307; 4, 383; 5, 435; 5, 487; 7, 233; 9, 219)

Humphreys, L. G. Generalization as a function of method of reinforcement. J. exp. Psychol., 1939, 25, 361-372. (9, 567)

Hundt, A. G. and Premack, D. Running as both a positive and negative reinforcer. Science, 1963, 142, 1087-1088. $(10,75)$

Hunsperger, R. W. Affektreaktionen auf electrische Reizung im Hirnstamm der Katze. Helv. Physiol. Acta, 1956, 14, 70-92. (9, 401)

Hunt, E. and Kimeldorf, D. Evidence for direct stimulation of the mammalian nervous system with ionizing radiation. Science, 1962, 137, 857-859. $(9,29)$

Hunt, H. F. and Brady, J. V. Some effects of punishment and intercurrent "anxiety" on a simple operant. J. comp. physiol. Psychol., $1955,48,305-310$. (7, 293; 8, 89; 9, 205; 10, 451)

Hunter, J. and Jasper, H. H. Effects of thalamic stimulation in unanesthetized animals. EEG clin. Neurophysiol., 1949, 1, 305-324. (2, 43)

Hunter, W. S. The delayed reaction in animals and children. Behav. Monogr., 1913, 2, 1-86. (2, 151; $5,225 ; 6,101 ; 10,529)$

Hunter, W. S. The temporal maze and kinaesthetic sensory processes in the white rat. Psychobiol., 1920, 2, 1-18. (8, 161; 9, 1)

Hunter, W. S. The behavior of raccoons in a double alternation temporal maze. J. genet. Psychol., 1928, 35, 374-388. (6, 271)

Hunter, W. S. and Nagge, J. W. The white rat and the double alternation temporal maze. $J$. genet. Psychol., 1931, 39, 303-319. (8, 161)

Hunter, W. S. Conditioning and extinction in the rat. Brit. J. Psychol., 1935, 26, 135-148. (5, 97; 9, 421)

Hurwitz, H. M. B. Response-duration of lever pressing in the rat. Quart. J. exp. Psychol., 1954, 6, 62-71. (1, 149; 4, 97; 4, 317; 6, 155; 6, 179)
Hurwitz, H. M. B. Response elimination without performance. Quart. J. exp. Psychol., 1955, 27, 1-7. (4, 331)

Hurwitz, H. M. B. Periodicity of response in operant extinction. Quart. J. exp. Psychol., 1957, 9, 177-184. (1, 149)

Hurwitz, H. M. B. and Millenson, J. R. Maintenance of avoidance behavior under temporally defined contingencies. Science, 1961, 133, 284285. $(5,97 ; 6,265 ; 6,361 ; 10,551)$

Hurwitz, H. M. B. and Dillow, P. V. Discrimination learning under avoidance schedules. In R. Gilbert (Ed.), Discrimination learning: $a$ symposium. Univ. Aberdeen: Exp. Anal. Behav. Group, 1967. (Mimeo.) Pp. 465-523. (10, 461)

Hutchinson, R. R., Ulrich, R. E., and Azrin, N. H. Effects of age and related factors on the painaggression reaction. J. comp. physiol. Psychol., 1965, 59, 365-369. (7, 223; 8, 171; 10, 311)

Hutt, P. J. Rate of bar pressing as a function of quality and quantity of food reward. J. comp. physiol. Psychol., 1954, 47, 235-239. (3, 293)

IBM. Automatic reading and recording of digital data using IBM summary punches. (4th ed) IBM pub. \#320-6185. White Plains, N.Y.: IBM. (6, 599)

IBM. General information manual: introduction to IBM data processing systems. White Plains, N.Y.: IBM, 1964. (9, 163)

Ingle, D. J. Limits of visual transfer in goldfish. Doctoral dissertation, Univ. Chicago, 1963. (9, 11)

Irwin, F. An analysis of the concepts of discrimination and preference. Amer. J. Psychol., 1958, 71, 152-163. $(10,375)$

Irwin, J. V. and Becklund, O. Norms for maximum repetitive rates for certain sounds established with the sylrater. J. speech hear. Dis., 1953, 18, 149-160. (3, 111)

Irwin, S. and Seevers, M. H. Altered responses to drugs in the post-addict (Macaca mulatta). $J$. Pharmacol. exp. Therap., 1956, 116, 31-32. (10, 235)

Irwin, S. Correlation in rats between the locomotor and avoidance-suppressant potencies of eight phenothiazine tranquilizers. Arch. int. Pharmacodyn., 1961, 132, 279-286. (6, 213)

Isaacs, W., Thomas, J., and Goldiamond, I. Application of operant conditioning to reinstate verbal behavior in psychotics. J. speech hear. Dis., 1960, 25, 8-12. (8, 357)

Ison, J. R. Experimental extinction as a function of number of reinforcements. J. exp. Psychol., 1962, 64, 314-317. (7, 135)

Israel, M. L. Variably blurred prompting: I. Methodology and application to the analysis 
of paired-associate learning. J. Psychol., 1960, 50, 43-52. (10, 479)

Itani, J. On the acquisition and propagation of a new food habit in the roop of Japanese monkeys at Takasakiyama. In $\mathrm{K}$. Imanishi and S. A. Altmann (Eds.), Japanese monkeys. Published by Altmann from NIH grant, 1965. Pp. 52-65. Originally published in Japanese in Primates, 1958, 2, 84-98. $(9,691)$

Jacobsen, E., Wollstein, A., and Christensen, J. T. Die Wirkung einiger Amine auf das zentrale Nervensystem. Klin. Wchnschr., 1938, 17, 15801583. $(3,293)$

Jacobsen, E. Studies on the subjective effects of the cephalotropic amines in man. Acta. Med. Scand., 1939, 100, 188-202. (3, 293)

Jacobsen, E. and Sonne, E. The effect of benzilic acid diethylaminoethylester $\mathrm{HCl}$ (Benactyzine) on stress-induced behavior in the rat. Acta Pharmacol. et Toxicol., 1955, 11, 135-147. (2, 107)

James, W. Principles of psychology. New York: Holt, 1890. 2 vols. (6, 1)

James, W. T. Social facilitation of eating behavior in puppies after satiation. J. comp. physiol. Psychol., 1953, 46, 427-428. (10, 387)

James, W. T. and Gilbert, T. F. The effect of social facilitation on food intake of puppies fed separately and together for the first 90 days of life. Brit. J. animal Behav., 1955, 111, 131-133. (10, 387)

James, W. T. An operant liquid dropping apparatus for rats. J. gen. Psychol., 1955, 53, 175177. $(7,78)$

James, W. T. and Cannon, D. J. Variation in social facilitation of eating behavior in puppies. J. genet. Psychol., 1955, 87, 225-228. (10, 387)

James, W. T. The development of social facilitation of eating in puppies. J. genet. Psychol., 1960, 96, 123-127. (10, 387)

Jasper, H. H. and Droogleever-Fortuyn, J. Experimental studies on the functional anatomy of the petit mal epilepsy. In Epilepsy, Publ. Assn. Res. nerv. ment. Dis. Baltimore: Williams \& Wilkins, 1947. Pp. 272-298. (2, 43)

Jasper, H. H. and Ajmone-Marsan, C. A stereotaxic atlas of the diencephalon of the cat. Ottawa: Nat. Res. Council of Canada, 1954. $(9,401 ; 10,277)$

Jaynes, J. Imprinting: the interaction of learned and innate behavior: II. The critical period. J. comp. physiol. Psychol., 1957, 50, 6-10. (9, 177)

Jenkins, H. M. and Harrison, R. H. Effect of discrimination training on auditory generalization. J. exp. Psychol., 1960, 59, 246-253. (4,
$157 ; 4,203 ; 4,371 ; 5,435 ; 6,1 ; 7,199 ; 8$, $47 ; 9,377 ; 9,649 ; 10,17 ; 10,361$ )

Jenkins, H. M. The effect of discrimination training on extinction. J. exp. Psychol., 1961, 61, 111-121. (4, 387; 6, 1; 6, 223)

Jenkins, H. M. Generalization gradients and the concept of inhibition. In D. I. Mostofsky (Ed.), Stimulus generalization. Stanford: Stanford Univ. Press, 1965. Pp. 55-61. (9, 305)

Jenkins, H. M. Measurement of stimulus control during discriminative operant conditioning. Psychol. Bull., 1965, 64, 365-376. (10, 185; 10, $251 ; 10,545)$

Jenkins, T. N. A standard problem box of multiple complexity for use in comparative studies. $J$. comp. Psychol., 1927, 7, 129-145. (6, 271)

Jenkins, W. O. and Clayton, Frances L. Rate of responding and amount of reinforcement. $J$. comp. physiol. Psychol., 1949, 42, 174-181. (4, $125 ; 6,299 ; 10,341 ; 10,417$ )

Jenkins, W. O. A temporal gradient of derived reinforcement. Amer. J. Psychol., 1950, 63, 237-243. (5, 543)

Jenkins, W. O. and Stanley, J. C. Partial reinforcement: a review and critique. Psychol. Bull., 1950, 47, 193-234. (4, 133; 7, 345)

Jenkins, W. O., Pascal, G. R., and Walker, R. W. Deprivation and generalization. J. exp. Psychol., 1958, 56, 274-277. (5, 19)

Jenney, Elizabeth H. and Healy, Shirley T. Drug antagonists to chlorpromazine inhibition of the conditioned response. Fed. Proc., 1959, 18, 407. $(6,395)$

Jetter, W. W., Lindsley, O. R., and Wohlwill, F. J. The effects of $x$-irradiation on physical exercise and behavior in the dog: related hematological and pathological control studies. Boston: Boston Univ., 1953. $(8,107)$

John, E. R. and Killam, K. F. Electrophysiological correlates of avoidance conditioning in the cat. J. Pharmacol. exp. Therap., 1959, 125, 252-274. $(5,467)$

Johnson, R. N. Use of reinforcing brain stimulation in discrimination learning. Percept. mot. Skills, 1965, 21, 366. (9, 17)

Johnson, Rochelle Gavalas. Operant reinforcement of an automatic response. Dissert. Abstr., 1963, 24, 1255. Order No. 63-6067. (10, 119)

Johnson, W. J. Stuttering in children and adults. Minneapolis: Univ. Minn. Press, 1955. (1, 173)

Jonckheere, A. R. A test of significance for the relation between $\mathrm{m}$ rankings and $\mathrm{k}$ ranked categories. Brit. J. statist. Psychol., 1954, 7, 93-100. (4, 371; 6, 575; 8, 89)

Jones, Joan E. Deviations from matching behavior in probability learning. J. Psychol., 1961, 52, 335-345. (6, 203)

Jones, L, V. Distinctiveness of color, form and 
position cues for pigeons. J. comp. physiol. Psychol., 1954, 47, 253-257. (7, 361)

Jones, M. T. and Stockham, M. A. The effect of previous stimulation of the adrenal cortex by adreno-corticotrophin on the function of the pituitary-adrenocortical axis in response to stress. J. Physiol., 1966, 184, 741-750. (10, 555)

Kagan, J. and Lemkin, J. Form, color, and size in children's conceptual behavior. Child Developm., 1961, 32, 25-28. (10, 375)

Kahn, M. W. The effect of severe defeat at various age levels on the aggressive behavior of mice. J. genet. Psychol., 1951, 79, 117-130. (7, 223)

Kalish, H. I. Strength of fear as a function of the number of acquisition and extinction trials. J. exp. Psychol., 1954, 47, 1-9. (5, 41)

Kalish, H. I. and Guttman, N. Stimulus generalization after equal training on two stimuli. $J$. exp. Psychol., 1957, 53, 139-144. (4, 157; 7, 199; $7,217 ; 9,631 ; 9,649)$

Kalish, H. I. The relationship between discriminability and generalization: a re-evaluation. $J$. exp. Psychol., 1958, 55, 637-644. (4, 31; 5, 375)

Kalish, H. I. and Guttman, N. Stimulus generalization after training on three stimuli: a test of the summation hypothesis. J. exp. Psychol., 1959, 57, 268-272. (2, 307; 4, 31; 4, 133; 4, 157; 7,$217 ; 9,631$ )

Kalish, H. I. and Haber, A. Generalization: I. Generalization gradients from single and multiple stimulus points. II. Generalization of inhibition. J. exp. Psychol., 1963, 65, 176-181. $(9,457)$

Kamin, L. J. Traumatic avoidance learning: the effects of CS-US interval with a trace conditioning procedure. J. comp. physiol. Psychol., $1954,47,65-72$. $(6,477)$

Kamin, L. J. The effects of termination of the CS and avoidance of the US on avoidance learning. J. comp. physiol. Psychol., 1956, 49, 420-424. (7, 315; 9, 421; 10, 451)

Kamin, L. J. The effects of termination of the CS and avoidance of the US on avoidance learning: an extension. Canad. J. Psychol., 1957, 11, 48-56. (5, 391; 9, 421)

Kamin, L. J. CS-termination as a factor in the emergence of anticipatory avoidance. Psychol. Rep., 1959, 5, 455-456. (5, 391)

Kanfer, F. H. Effect of a warning signal preceding a noxious stimulus on verbal rate and heart rate. J. exp. Psychol., 1958, 55, 73-80. (4, 197)

Kanfer, F. H. Verbal conditioning: reinforcement schedules and experimenter influence. Psychol. Rep., 1958, 4, 443-452. (4, 197)

Kaplan, M. The effects of noxious stimulus intensity and duration during intermittent reinforcement of escape behavior. J. comp. physiol. Psychol., 1952, 45, 538-549. (1, 45; 1, 145; 2, 23;
3,$255 ; 6,361 ; 8,31 ; 8,117 ; 8,321 ; 8,419 ; 9$, 267)

Kaplan, M. The maintenance of escape behavior under fixed-ratio reinforcement. J. comp. physiol. Psychol., 1956, 49, 153-157. (1, 45; 2, $23 ; 6,519 ; 8,31 ; 8,117 ; 9,131 ; 9,267 ; 10$, $109 ; 10,131)$

Kaplan, M. Intensity-escape functions under interval schedules of reinforcement. Psychol. Rep., 1957, 3, 251-254. (8, 117; 8, 321)

Kaplan, M. Amplitude of respiratory movements as a function of noxious stimulus intensity. Psychol. Rep., 1957, 3, 429-438. (8, 321)

Karn, H. W. and Patton, R. A. The role of transportation cues in double alternation behavior by the rat in a multiple box apparatus. $J$. comp. Psychol., 1941, 32, 443-446. (8, 161)

Kasl, S. V. and Mahl, G. F. A simple device for obtaining certain verbal activity measures during interviews. J. abnorm. soc. Psychol., 1956, 53, 388-390. (7, 99)

Kaufman, A. Effects of punishment intensity on human operant behavior. Psychol. Rep., 1964, 15, 287-294. (8, 389)

Kaufman, A. Increased suppression during punishment applied to the responding member. Psychon. Sci., 1964, 1, 311-312. (8, 389)

Kavenaugh, J. L. and Norris, K. S. Behavior studies by capacitance sensing. Science, 1961, 134, 730732. $(8,215)$

Kavenaugh, J. L. Identification of small animals by proximity sensing. Science, 1961, 134, 16941696. $(8,215)$

Keehn, J. D. A proactive restatement of the law of effect. Psychol. Rep., 1959, 5, 709-711. (10, 461)

Keehn, J. D. Running and bar pressing as avoidance responses. Psychol. Rep., 1967, 20, 591602. $(10,461)$

Keehn, J. D. Double discrimination bar-press and bar-release avoidance. Psychon. Sci., 1967, 8, 189-190. (10, 461)

Keehn, J. D. Discrimination and avoidance behavior. In R. Gilbert (Ed.), Discrimination learning: a symposium. Univ. Aberdeen: Exp. Anal. Behav. Group, 1967. (Mimeo.) Pp. 73102. $(10,461)$

Keesey, R: E. The relationship between pulse frequency, intensity and duration and the rate of responding for intracranial stimulation. $J$. comp. physiol. Psychol., 1962, 55, 671-678. (8, 75)

Keister, W., Ritchie, A. E., and Washburn, S. H. The design of switching circuits. New York: Van Nostrand, 1951. (9, 689)

Kelleher, R. T. Intermittent conditioned reinforcement in chimpanzees. Science, 1956, 124, 679680. $(1,281 ; 4,393 ; 5,543)$

Kelleher, $R$. T. Conditioned reinforcement in 
chimpanzees. J. comp. physiol. Psychol., 1957, 49, 571-575. (1, 281; 4, 393; 5, 167; 5, 543; 7, 83; 8, 243; 8, 357; 9, 475)

Kelleher, R. T. A comparison of conditioned and food reinforcement in chimpanzees. Psychol. Newsltr., 1957, 8, 88-93. $(5,543)$

Kelleher, R. T. A multiple schedule of conditioned reinforcement with chimpanzees. Psychol. Rep., 1957, 3, 485-491. (1, 281; 4, 393; 5, 543; 7, 83)

Kelleher, R. T. Concept formation in chimpanzees. Science, 1958, 128, 777-778. (4, 393)

Kelleher, R. T. and Cook, L. Effects of chlorpromazine, meprobamate, $d$-amphetamine, mephenesin, or phenobarbital on time discrimination in rats. Pharmacologist, 1959, 2, 51. (5, 73)

Kelleher, R. T., Riddle, W. C., and Cook, L. A behavioral analysis of qualitative differences among phenothiazines. Fed. Proc., 1960, 19, 22. $(4,84 ; 5,73)$

Kelleher, R. T., Fry, W., Deegan, J., and Cook, L. Effects of meprobamate on operant behavior in rats. J. Pharmacol. exp. Therap., 1961, 133, 271-280. (6, 125; 7, 69;9, 389; 10, 485)

Kelleher, R. T. and Morse, W. H. Escape behavior and punished behavior. Fed. Proc., 1964, 23, 808-817. (8, 419; 9, 267; 10, 109; 10, 439)

Kelleher, R. T. Chaining and conditioned reinforcement. In W. K. Honig (Ed.), Operant behavior: areas of research and application. New York: Appleton-Century-Crofts, 1966. Pp. $160-212$. (8, 125; 8, 427; 9, 573; 10, 45; 10, 175; $10,271 ; 10,331 ; 10,341)$

Keller, F. S. Light aversion in the white rats. Psychol. Rec., 1941, 4, 235-250. (1, 145; 1, 167; 2,$23 ; 3,207 ; 6,65 ; 6,75 ; 6,361 ; 8,117 ; 8$, $321 ; 9,267)$

Keller, F. S. Studies in International Morse code: I. A new method of teaching code reception. J. appl. Psychol., 1943, 27, 407-415. (1, 1)

Keller, F. S. and Schoenfeld, W. N. Principles of psychology. New York: Appleton-CenturyCrofts, 1950. (1, 45; 1, 173; 2, 1; 3, 275; 4, 7; 5,$113 ; 5,317 ; 5,481 ; 5,511 ; 5,543 ; 6,1$; 6,$75 ; 6,477 ; 7,107 ; 7,357 ; 7,401 ; 8,9 ; 8$, $31 ; 8,269 ; 9,191 ; 9,205 ; 9,267 ; 9,293 ; 9$, $547 ; 10,45 ; 10,131 ; 10,185 ; 10,281 ; 10,291$; 10, 331)

Kellogg, W. N. The time of judgment in psychometric measures. Amer. J. Psychol., 1931, 43, 65-86. (5, 487)

Kellogg, W. N. Echo-ranging in the porpoise. Science, 1958, 128, 982-988. (9, 535)

Kellogg, W. N. Auditory scanning in the dolphin. Psychol. Rec., 1960, 10, 25-27. (9, 535)

Kelly, C. M. and Carr, H. The curve of learning in typesetting. J. exp. Psychol., 1924, 7, 447 . 455. $(5,15)$

Kendall, M. G. and S. A. The advanced theory of statistics. Vol. 1. Distribution theory. (2nd ed.) New York: Hafner, 1963. (8, 9)

Kendall, S. B. An observing response analysis of fixed ratio discrimination. Psychon. Sci., 1965, 3, 281-282. (9, 337)

Kendler, H. H. and Levine, S. Studies of the effect of change of drive: I. From hunger to thirst in a T-maze. J. exp. Psychol., 1951, 41, 429-436. $(3,323)$

Kendler, H. H., Levine, S., Altchek, E., and Peters, $H$. Studies of the effect of change of drive: II. From hunger to different intensities of a thirst drive in a T-maze. J. exp. Psychol., 1952, 44, 1-3. (3, 323)

Kendler, H. H., Karasik, A. D., and Schrier, A. M. Studies of the effect of change of drive: III. Amounts of switching produced by shifting drive from thirst to hunger and from hunger to thirst. J. exp. Psychol., 1954, 47, 179-182. $(3,323)$

Kendler, H. H. Learning. Annual Rev. Psychol., 1959, 16, 43-88. $(5,543)$

Key, B. J. and Marley, E. A simple technique for recording the electrocorticogram in small animals. J. Physiol., 1961, 155, 29-30. (9, 95)

Key, B. J. and Marley, E. The effect of the sympathomimetic amines on behavior and electrocortical activity of the chicken. EEG clin. Neurophysiol., 1962, 14, 90-105. (9, 95)

Kientzle, M. J. Properties of learning curves under varied distributions of practice. J. exp. Psychol., 1946, 36, 187-211. (5, 15)

Kimble, G. A. Performance and reminiscence in motor learning as a function of the degree of distribution of practice. J. exp. Psychol., 1949, 39, 500-510. (5, 15)

Kimble, G. A. Shock intensity and avoidance learning. J. comp. physiol. Psychol., 1955, 48, 281284. (4, 309)

Kimble, G. A. Hilgard and Marquis' conditioning and learning. New York: Appleton-CenturyCrofts, 1961. (5, 191; 6, 1; 6, 343; 6, 477; 7, $233 ; 8,269 ; 9,69 ; 10,45)$

Kimmel, H. D. and Hill, Frances A. Operant conditioning of the GSR. Psychol. Rep., 1960, 7, 555-562. (5, 317; 10, 119)

King, G. F., Merrell, D. W., Lovinger, E., and Denny, M. R. Operant motor behavior in acute schizophrenics. J. Pers., 1957, 25, 317-326. $(3,111 ; 5,343)$

King, J. A. Social relations of the domestic guinea pig living under semi-natural conditions. Ecology, 1956, 37, 221-228. (2, 219)

Kinnard, W. J., Aceto, M. D. G., and Buckley, J. P. The effects of certain psychotropic agents on the conditioned emotional response behavior pattern of the albino rat. Psychopharmacologia, 1962, 3, 227-230. (10, 565)

Kissel, J. W. Nutating annular cage for measuring 
motor activity. Science, 1963, 139, 1224-1225. (8, 215)

Klemm, W. R. Potentiation of animal "hypnosis" with. low levels of electric current. Animal Behav., 1965, 13, 571-574. $(9,63)$

Klemm, W. R. Drug potentiation of hypnotic restraint of rabbits, as indicated by behavior and brain electrical activity. Lab. Animal Care, 1965, 15, 163-167. $(9,63)$

Kling, J. W. Speed of running as a function of goal-box behavior. J. comp. physiol. Psychol., 1956, 49, 474-476. (10, 417)

Klüver, H. Behavior mechanisms in monkeys. Chicago: Univ. Chicago Press, 1933. (2, 127; 10, 467)

Knoefel, P. K. Stimulation and depression of the central nervous system by derivatives of barbituric and thiobarbituric acids. J. Pharmacol. exp. Therap., 1945, 84, 26-33. $(6,125)$

Koch, A. M. The limits of learning ability in cebus monkeys. Genet. Psychol. Monogr., 1935, 17, 163-234. (6, 271)

Kohts, N. Recherches sur l'intelligence du chimpanzé par la methode de "choix d'aprés modele." J. de Psychol., 1928, 25, 255-275. (6, 101)

Konorski, J. and Miller, S. Methode d'examen de l'analysateur moteur par les réactions salivomotrices. C.R. Soc. Biol., 1930, 104, 907-910. $(8,405)$

Konorski, J. and Miller, S. On two types of conditioned reflex. J. gen. Psychol., 1937, 16, 264-272. $(5,383 ; 8,405 ; 10,405)$

Konorski, J. Conditioned reflexes and neuron organization. Cambridge: Cambridge Univ. Press, 1948. (5, 383)

Konorski, J. Salivary and motor conditioning. Science, 1961, 133, 1284-1286. (8, 405)

Kovach, J. K. and Hess, E. H. Imprinting: effects of painful stimulation upon the following response. J. comp. physiol. Psychol., 1963, 56, 461-464. (9, 177)

Krasner, L. Studies of the conditioning of verbal behavior. Psychol. Bull., 1958, 55, 148-170. (3, $111 ; 3,183 ; 4,171 ; 5,383$ )

Krechevsky, I. "Hypotheses" in rats. Psychol. Rev., 1932, 39, 516-532. (5, 279)

Krechevsky, I. A study of the continuity of the problem-solving process. Psychol. Rev., 1938, 45, 107-133. (9, 593)

Krieckhaus, E. E., Miller, N. E., and Zimmerman, P. Reduction of freezing behavior and improvement of shock avoidance by $d$-amphetamine. J. comp. physiol. Psychol., 1965, 60, 36-40. (9, 389; 10, 485)

Kryter, K. D. The effects of noise on man. J. speech hear. Dis., 1950, 15, (Monogr. Suppl. 1). (1, 183)

Kuhn, R. The treatment of depressive states with
G22355 (imipramine hydrochloride). Amer. J. Psychiat., 1958, 115, 459-464. (6, 213)

LaBerge, D. Generalization gradients in a discrimination situation. J. exp. Psychol., 1961, 62, 88-94. (5, 487; 7, 303)

Lacey, J. I. and Lacey, Beatrice C. The relationship of resting autonomic activity to motor impulsivity. Proc. Assn. Res. nerv. ment. Dis., 1958, 36, 144-209. (5, 317)

Lagmay, A. V. A pacing technique in the study of some schedules of reinforcement. Doctoral dissertation, Harvard, 1955. (1, 45; 1, 59; 1, 109)

Laird, D. A. and Coye, K. Psychological measurements of annoyance as related to pitch and loudness. J. acoust. Soc. Amer., 1929, 1, 158163. $(1,183)$

Lajtha, A. The development of the blood-brain barrier. J. Neurochem., 1957, 1, 216-227. $(9,95)$

Lane, H. L. Some characteristics of vocal responding. Paper read at APA, New York, Sept. 1957. $(3,183)$

Lane, H. L. Operant control of vocal behavior in chickens. Doctoral dissertation, Harvard, 1960. $(4,171)$

Lane, H. L. Control of vocal responding in chickens. Science, 1960, 132, 37-38. (4, 171; 4, 197; 5,383 )

Lane, H. L. Psychophysical parameters of vowel perception. Psychol. Monogr., 1962, 76 (44, Whole No. 563). (6, 179)

Larsson, K. Conditioning and sexual behavior in the male albino rat. Stockholm: Almquist \& Wiksell, 1956. (10, 219)

Lasagna, L. and McCann, W. P. Effect of "tranquilizing" drugs on amphetamine toxicity in aggregated mice. Science, 1957, 125, 1241-1242. $(4,17 ; 6,395)$

Lashley, K. S. The mechanism of vision: XV. Preliminary studies of the rat's capacity for detail vision. J. gen. Psychol., 1938, 18, 123-193. (4, $203 ; 6,223 ; 9,11 ; 9,567$ )

Lashley, K. S. Conditional reactions in the rat. J. Psychol., 1938, 6, 311-324. (5, 279; 6, 101)

Laties, V. G. and Weiss, B. Effects of alcohol on timing behavior. J. comp. physiol. Psyckol., 1962, 55, 85-91. (6, 281; 6, 431; 8, 107)

Lauener, $\mathrm{H}$. Conditioned suppression in rats and the effect of pharmacological agents thereon. Psychopharmacologia, 1963, 4, 311-325. (10, 565)

Lauer, D. W. and Estes, W. K. Successive acquisitions and extinctions of a jumping habit in relation to schedule of reinforcement. J. comp. physiol. Psychol., 1955, 48, 8-13. (5, 481)

Law, T. and Wise, H. W. A multiple electrode carrier for chronic implantation in small animals. EEG clin. Neurophysiol., 1958, 10, 749- 
751. (4, 44)

Lawicka, W. The effect of the prefrontal lobectomy on the vocal conditioned reflexes in dogs. Acta Biol. exp., 1957, 17, 317-325. (5, 383)

Lawrence, D. H. and Miller, N. E. A positive relationship between reinforcement and resistance to extinction produced by removing a source of confusion from a technique that had produced opposite results. J. exp. Psychol., 1947, 37, 494-509. (1, 149)

Lawrence, D. H. The transfer of a discrimination along a continuum. J. comp. physiol. Psychol., 1952, 45, 511-516. (5, 279; 6, 1; 10, 3; 10, 17)

Lawrence, D. H. The applicability of generalization gradients to the transfer of a discrimination. J. gen. Psychol., 1955, 52, 37-48. (5, 279)

Lawson, R. Amount of primary reward and strength of secondary reward. J. exp. Psychol., 1953, 46, 183-187. (5, 543)

Lawson, R. Brightness discrimination performance and secondary reward strength as a function of primary reward amount. J. comp. physiol. Psychol., 1957, 50, 35-39. (5, 543)

Lawson, R. Frustration: the development of a scientific concept. New York: Macmillan, 1965. $(\mathbf{1 0}, \mathbf{3 4 9})$

Lazarus, R. S., Speisman, J. C., and Mordkoff, A. M. The relationship between autonomic indicators of physiological stress: heart rate and skin conductance. Psychosomat. Med., 1963, 25, 19-30. (10, 119)

Leaf, R. C. Acquisition of Sidman avoidance responding as a function of S-S interval. J. comp. physiol. Psychol., 1965, 59, 298-300. (9, 557)

Leckrone, W. R., Zimmerman, J., and Hanford, P. V. A pigeon magazine shutter for preventing unprogrammed grain reinforcement. Psychon. Sci., 1966, 6, 239-240. (10, 331)

Leiderman, P. H. and Shapiro, D. Application of a time series statistic to physiology and psychology. Science, 1962, 138, 141-142. (10, 555)

Leitenberg, $\mathrm{H}$. Is time-out from positive reinforcement an aversive event? a review of the experimental evidence. Psychol. Bull., 1965, 64, 428-441. (9, 205; 9, 557; 10, 439)

Leitenberg, $\mathrm{H}$. Conditioned acceleration vs conditioned suppression in pigeons. Doctoral dissertation, Indiana, 1965. (9, 205)

Le Ny, J. F. Généralisation d'une attitude dans une épreuve de temps de réaction. Année psychol., 1957, 57, 11-21. (5, 487)

Levi, W. M. The pigeon. Columbia, S.C.: Bryan, 1957. $(2,161 ; 6,73 ; 7,361 ; 9,191)$

Levine, G. Stimulus-response generalization with discrete response choices. J. exp. Psychol., 1960, 60, 23-29. (5, 487)

Levine, J. Studies in the interrelations of central nervous structures in binocular vision: $I$. The lack of bilateral transfer of visual discrimina- tive habits acquired monocularly by the pigeon. J. genet. Psychol., 1945, 67, 105-129. (6, $627 ; 7,361 ; 8,147$ )

Levine, J. Studies in the interrelations of central nervous structures in binocular vision: II. The conditions under which interocular transfer of discriminative habits takes place in the pigeon. J. genet. Psychol., 1945, 67, 131-142. (6, 623; 7,$361 ; 8,147 ; 9,11$ )

Levine, J. Studies in the interrelations of central nervous structures in binocular vision: III. Localization of the memory trace as evidenced by the lack of inter- and intraocular habit transfer in the pigeon. J. genet. Psychol., 1952, 81, 19-27. (7, 361; 8, 147)

Levine, M. Hypothesis behavior. In A. M. Schrier, H. F. Harlow, and F. Stollnitz (Eds.), Behavior of nonhuman primates. Vol. 1. New York: Academic Press, 1965. Pp. 97-127. (10, 3)

Levine, S. and Jones, Lucy. Adrenocorticotropic hormone (ACTH) and passive avoidance learning. J. comp. physiol. Psychol., 1965, 59, 357360. $(10,555)$

Lewis, D. J. and Duncan, C. P. Effect of different percentages of money reward on extinction of a lever-pulling response. J. exp. Psychol., 1956, 52, 23-27. (3, 111)

Lewis, D. J. and Duncan, C. P. Expectation and resistance to extinction of a lever-pulling response as a function of percentage of reinforcement and number of acquisition trials. $J$. exp. Psychol., 1958, 55, 121-128. (8, 255)

Lewis, D. J. Quantitative methods in psychology. New York: McGraw-Hill, 1960. (10, 545)

Lewis, M. Behavior resulting from sodium chloride deprivation in adrenalectomized rats. J. comp. physiol. Psychol., 1960, 53, 464-467. (8, 295)

Libaw, Frieda Bornston. The effects of prior partexperiences on visual form perception in the albino rat. Doctoral dissertation, Univ. Southern California, 1961. (6, 177)

Libby, A. Two variables in the acquisition of depressant properties by a stimulus. $J$. exp. Psychol., 1951, 42, 100-107. (1, 265; 9, 245)

Liberman, A. M. Some results of research on speech perception. J. acoust. Soc. Amer., 1957, 29, 117 123. $(5,487)$

Liberman, A. M., Harris, K. S., Kinney, J., and Lane, $H$. An effect of learning on perception: the discrimination of relative onset time of the components of certain speech and non-speech patterns. J. exp. Psychol., 1961, 61, 379-389. (5, 487)

Liberson, W. T. Prolonged hypnotic states with "local signs" induced in guinea pigs. Science, $1948,108,40-41 .(9,63)$

Liberson, W. T. and Akert, K. Hippocampal seizure states in guinea pigs. EEG clin. Neurophysiol., 1955, 7, 211-222. (2, 43) 
Licklider, J. C. R. Basic correlates of the auditory stimulus. In S. S. Stevens (Ed.), Handbook of experimental psychology. New York: Wiley, 1951. Pp. 985-1039. (8, 385)

Liddell, H. S., James, W. T., and Anderson, O. D. The comparative physiology of the conditioned motor reflex, based on experiments with the pig, dog, sheep, goat, and rabbit. Comp. Psychol. Monogr., 1934, 11, 1-89. (7, 263)

Liddell, H. S. The challenge of Pavlovian conditioning and experimental neuroses in animals. In J. Wolpe, A. Salter, and L. J. Reyna (Eds.), The conditioning therapies. New York: Holt, Rinehart \& Winston, 1964. Pp. 127-148. (10, 387)

Lilly, J. C., Hughes, J. R., Alvord, E. C., and Galkin, T. W. Brief, non-injurious electric waveform for stimulation of the brain. Science, $1955,121,468-469$. $(2,43 ; 3,93)$

Lilly, J. C. Learning motivated by subcortical stimulation: the start and stop patterns of behavior. In H. Jasper (Ed.), Reticular formation of the brain. Boston: Little, Brown, 1958. Pp. 705-721. (2, 43)

Lindquist, E. F. Design and analysis of experiments in psychology and education. Boston: Houghton Mifflin, 1953. $(9,219)$

Lindsley, D. B. Emotion. In S. S. Stevens (Ed.), Handbook of experimental psychology. New York: Wiley, 1951. Pp. 473-516. (6, 477)

Lindsley, $\mathbf{O}$. R. and Jetter, W. W. The temporary elimination of discrimination and fear by sodium pentobarbital injections (dogs). Amer. Psychologist, 1953, 8, 390. (Abstract) (6, 29)

Lindsley, O. R. and Skinner, B. F. A method for the experimental analysis of the behavior of psychotic patients. Amer. Psychologist, 1954, 9, 419-420. (Abstract) (3, 111)

Lindsley, $O$. R. Operant conditioning methods applied to research in chronic schizophrenia. Psychiat. res. Rpts., 1956, 5, 118-139. (3, 63; 3, $111 ; 5,343 ; 7,327 ; 7,430 ; 8,357 ; 9,411)$

Lindsley, O. R. Operant behavior during sleep: a measure of depth of sleep. Science, 1957, 126, 1290-1291. (2, 133; 2, 227; 7, 69)

Lindsley, O. R. Characteristics of the behavior of chronic psychotics as revealed by free operant methods. Dis. nerv. System, 1960, 21, 3-15. $(6,407)$

Lindsley, O. R. A behavioral measure of television viewing. J. adv. Res., 1962, 2, 2-12. (10, 479)

Lindsley, O. R. Experimental analysis of social reinforcement. Amer. J. Orthopsychiat., 1963, $33,624-633$. $(9,691)$

Lipsitt, L. P. Learning in the first year of life. In L. P. Lipsitt and C. C. Spiker (Eds.), $A d$ vances in child development and behavior. Vol. 1. New York: Academic Press, 1963. Pp. 147-195. $(9,105)$
Lisk, R. D. Inhibitory centers in sexual behavior in the male rat. Science, 1966, 152, 669-670. $(10,213)$

Lissmann, H. W. Die Umwelt des Kampffisches (Betta splendens Regan). Z. vergl. Physiol., 1932, 18, 62-111. (8, 341; 8, 397)

Littman, R. A. Conditioned generalization of the galvanic skin response to tones. J. exp. Psy. chol., 1949, 39, 868-882. (4, 371)

Lockard, R. B. Some effects of light upon the behavior of rodents. Psychol. Bull., 1963, 60, 509529. $(10,75)$

Logan, F. A. A note on stimulus intensity dynamism (V). Psych. Rev., 1954, 61, 77-80. (2, 307)

Logan, F. A. Incentive: how the conditions of reinforcement affect the performance of rats. New Haven: Yale Univ. Press, 1960. $(4,277 ; 5,543$; 7,$207 ; 10,67$ )

Long, E. R. The use of operant conditioning techniques in children. In S. Fisher (Ed.), Child research in psychopharmacology. Springfield, Ill.: Thomas, 1959. Pp. 111-124. (4, 233)

Longo, N. and Bitterman, M. E. Improved apparatus for the study of learning in fish. Amer. J. Psychol., 1959, 72, 616-620. (6, 279; 6, 301; 7, 345; 10, 191)

Longo, N. and Bitterman, M. E. The effects of partial reinforcement with spaced practice on resistance to extinction in the fish. J. comp. physiol. Psychol., 1960, 53, 169-172. (7, 345)

Longo, N., Holland, L. R., and Bitterman, M. E. The resistive sheet: a gridless and wireless shocking technique. Amer. J. Psychol., 1961, 74, 612-618. (6, 301)

Longo, N., Milstein, Sandra, and Bitterman, M. E. Classical conditioning in the pigeon: exploratory studies of partial reinforcement. J. comp. physiol. Psychol., 1962, 55, 983-986. (9, 681)

Longo, N. Probability-learning and habit-reversal in the cockroach. Amer. J. Psychol., 1964, 77, 29-41. $(7,151)$

Longo, N., Klempay, Suzanne, and Bitterman, M. E. Classical appetitive conditioning in the pigeon. Psychon. Sci., 1964, 1, 19-20. (9, 681)

Lorenz, K. Ritualized fighting. In J. D. Carthy and F. J. Ebling (Eds.), The natural history of aggression. New York: Academic Press, 1964. Pp. 39-50. (10, 131)

Lorenz, K. On aggression. New York: Harcourt, Brace, \& World, 1966. (10, 131; 10, 395)

Loucks, R. B. Efficacy of the rat's motor cortex in delayed alternation. J. comp. Neurol., 1931, 53, 511-567. $(9,671)$

Loucks, R. B. Methods of isolating stimulation effects with implanted barriers. In D. E. Sheer (Ed.), Electrical stimulation of the brain. Austin: Univ. Texas Press, 1961. Pp. 145-154. $(9,681)$

Lovaas, O. I., Berberich, J. P., Perloff, B. F., and 
Schaeffer, B. Acquisition of imitative speech by schizophrenic children. Science, 1966, 151, 705-707. (10, 405)

Lubow, R. E. and Moore, A. U. Latent inhibition: the effect of non-reinforced presentation of the to be conditioned stimulus. J. comp. physiol. Psychol., 1959, 52, 415-419. (7, 423)

Lubow, R. E. Latent inhibition: effects of frequency of nonreinforced pre-exposure of the CS. J. comp. physiol. Psychol., 1965, 60, 454457. $(9,681)$

Luhby, A. L., Cooperman, J. M., and Halkin, C. R. Effect of Marsilid on weight and growth of children. J. clin. exp. Psychopath. \& Quart. Rev. Psychiatr. Neurol., 1957, 19, 132-136. (2, 271)

Lumb, W. V. Small animal anesthesia. Philadelphia: Lea \& Febiger, 1963. $(9,243)$

Luria, A. The role of speech in the regulation of normal and abnormal behavior. Trans. with intro. by J. Tizard. New York: Liveright, 1961. $(6,431)$

Lykken, D. T. and Rose, R. A rat-holder with electrodes for GSR measurement. Amer. J. Psy. chol., 1959, 72, 621-622. (9, 605)

Lykken, D. T. Properties of the electrodes used in electrodermal measurement. J. comp. physiol. Psychol., 1959, 52, 629-634. (8, 207)

Lyon, $M$. The role of central midbrain structures in conditioned responding to aversive noise in the rat. J. comp. Neurol., 1964, 122, 407-429. $(9,857)$

Macirone, C. and Walton, A. Fecundity of male rabbits as determined by "dummy matings." J. agric. Sci., 1938, 28, 122-134. (10, 219)

Mackintosh, J. and Sutherland, N. S. Visual discrimination by the goldfish: the orientation of rectangles. Animal Behav., 1963, 11, 135-141. $(9,11 ; 9,567)$

Mackintosh, N. J. Selective attention in animal discrimination learning. Psychol. Bull., 1965, 64, 124-150. $(9,593)$

Mackworth, N. H. Researches on the measurement of human performance. Med. res. Council spec. rep. Ser., 1950, No. 268. $(8,207)$

MacLean, P. D. The limbic system with respect to two basic life principles. In M. A. B. Brazier (Ed.), The central nervous system and behavior, Trans. 2nd Conf. New York: Josiah Macy, Jr. Found., 1959. Pp. 31-118. (6, 249)

Maffi, G. The secondary conditioned response of rats and the effects of some psychopharmacological agents. J. Pharm. \& Pharmacol., 1959, 11, 129-139. (2, 271)

Mahl, G. F. Exploring emotional states by content analysis. In I. Pool (Ed.), Trends in content analysis. Urbana: Univ. Ill. Press, 1960. Pp. 85-130. $(7,99)$
Maietta, F. A study of generalization and extinction in eyelid conditioning to pure tone auditory stimuli. Doctoral dissertation, Univ. Pittsburgh, 1955. $(2,212)$

Malmo, R. B. On central and autonomic nervous system mechanisms in conditioning, learning and performance. Canad. J. Psychol., 1963, 17, 1-36. $(8,181)$

Malott, R. W. The differential reinforcement of temporally spaced responses. Doctoral dissertation, Columbia, 1963. (9, 317; see also Malott and Cumming, Psych. Rec., 1964)

Malott, R. W. and Cumming, W. W. Schedules of interresponse time reinforcement. Psych. Rec., $1964,14,211-252$. (7, 391; 8, 107; 8, 255; 9, $87 ; 9,317 ; 10,425)$

Malott, R. W. and Cumming, W. W. Interresponse time reinforcement: transition and steady states. Psychon. Sci., 1965, 2, 257-258. (9, 317)

Mann, H. B. and Whitney, D. R. On a test of whether one of two random variables is stochastically larger than the other. Ann. math. Statist., 1947, 18, 50-60. (2, 1)

Margolius, G. Stimulus generalization of an instrumental response as a function of number of reinforced trials. J. exp. Psychol., 1955, 49, 105111. $(1,303 ; 6,1)$

Marquis, D. G. and Hilgard, E. R. Conditioned responses to light in monkeys after removal of the occipital lobes. Brain, 1937, 60, 1-12. (9, 601)

Marr, M. J. Schedule performance maintained by conditioned reinforcement. Master's thesis, Univ. North Carolina, 1965. (10, 271)

Martin, B. The assessment of anxiety by physiological behavioral measures. Psychol. Rev., 1961, 58, 234-255. (6, 477)

Marx, M. A stimulus-response analysis of the hoarding habit in the rat. Psychol. Rev., 1950, 57, 80-93. (3, 154)

Mason, D. J. The relation of secondary reinforcement to partial reinforcement. J. comp. physiol. Psychol., 1957, 50, 264-268. (5, 543)

Mason, J. W., Harwood, T., and Rosenthal, N. R. Influence of some environmental factors on plasma and urinary 17-hydroxycorticosteroid levels in the rhesus monkey. Amer. J. Physiol., 1957, 190, 429-433. (5, 353)

Mason, J. W., Brady, J. V., and Sidman, M. Plasma 17-hydroxycorticosteroid levels and conditioned behavior in the rhesus monkey. Endocrinol., 1957, 60, 741-752. (5, 353; 10, 555)

Mason, J. W. The central nervous system regulation of ACTH secretion. In H. Jasper (Ed.), Reticular formation of the brain. Boston: Little, Brown, 1958. Pp. 645-662. (5, 353)

Mason, J. W. Restraining chair for the experimental study of primates. J. appl. Physiol., 
$1958,12,130-133 .(2,43 ; 3,93 ; 5,353 ; 5,467 ; 5$, $473 ; 6,61)$

Masserman, J. H. Behavior and neurosis. Chicago: Univ. Chicago Press, 1943. (10, 387)

Masserman, J. H. Principles of dynamic psychiatry. Philadelphia: Saunders, 1946. (6, 399; 8, 55)

Masserman, J. H. and Yum, K. S. An analysis of the influence of alcohol on experimental neurosis in cats. Psychosomat. Med., 1946, 8, 36-52. (7, 293)

Masserman, J. H. and Pechtel, C. Neurosis in monkeys: a preliminary report of experimental observations. Ann. N.Y. Acad. Sci., 1953, 56, 253-265. (10, 95)

Masserman, J. H., Wechkin, S., and Terris, W. "Altruistic" behavior in rhesus monkeys. Amer. $J$. Psychiat., 1964, 121, 584-585. (9, 691)

Massopust, L. C., Jr. Diencephalon of the rat. In D. E. Sheer (Ed.), Electrical stimulation of the brain. Austin: Univ. Texas Press, 1961. Pp. 182-202. (8, 75; 10, 281; 10, 517)

Matthews, L. H. Overt fighting in mammals. In J. D. Carthy and F. J. Ebling (Eds.), The natural history of aggression. New York: Academic Press, 1964. Pp. 23-32. (10, 131)

May, M. A. Experimentally acquired drives. J. exp. Psychol., 1948, 38, 66-77. (6, 47)

McCann, G. D. Nervous system research with computers. Science, 1965, 148, 1565-1571. (9, 163)

McCleary, R. A. Type of response as a factor in interocular transfer in the fish. J. comp. physiol. Psychol., 1960, 4, 811-321. (8, 147)

McClelland, D. C. and McGown, D. R. The effect of variable food reinforcement on the strength of a secondary reward. J. comp. physiol. Psychol., 1953, 46, 80-86. $(5,543)$

McConnell, D. G., Polidora, V. J., Friedman, M., and Meyer, D. R. Automatic reading and recording of digital data in the analysis of primate behavior. IRE Trans., 1959, 48, 221-224. $(6,599)$

McCormack, P. D. Performance in a vigilance task as a function of interstimulus interval and interpolated rest. Canad. J. Psychol., 1958, 12, 242-246. (8, 207)

McCormack, P. D. Performance in a vigilance task with and without knowledge of results. Canad. J. Psychol., 1959, 13, 68-71. (8, 207)

McCulloch, T. L. and Pratt, J. G. A study of presolution in weight discrimination by white rats. J. comp. Psychol., 1934, 18, 271-290. (5, 279)

McCulloch, T. L. The role of clasping activity in adaptive behavior of the infant chimpanzee: I, II, III. J. Psychol., 1939, 7, 283-316. (1, 83)

McDiarmid, C. G. and Rilling, M. E. Reinforcement and reinforcement rate as determinants of schedule preference. Psychon. Sci., 1965, 2, 195-196. (10, 341)

McGeoch, J. A. and Irion, A. L. The psychology of human learning. New York: McKay, 1952. $(8,385)$

McGill, W. J. Stochastic latency mechanisms. In R. D. Luce, R. R. Bush, and E. Galanter (Eds.), Handbook of mathematical psychology. Vol. 1. New York: Wiley, 1963. Pp. 309-360. (7, 309; $8,131 ; 8,347 ; 9,135 ; 9,581 ; 10,425)$

McKelvey, R. K. The relationship between training methods and reward variable in brightness discrimination learning. J. comp. physiol. Psychol., 1956, 49, 485-491. (10, 417)

Mechner, F. and Berryman, R. The establishment of a discrimination based on behavior-produced cues. Paper read at EPA, Atlantic City, April 1956. (1, 163)

Mechner, F., Snapper, A. G., and Ray, R. Behavioral effects of methamphetamine and methylphenidate in rat and man. Neuro-psychopharmacol., 1960, 2, 31-35. (5, 463)

Mednick, Martha T. and Lindsley, O. R. Some clinical correlates of operant behavior. $J$. $a b$ norm. soc. Psychol., 1958, 57, 13-16. (3, 63)

Mednick, S. A. A learning theory approach to research in schizophrenia. Psychol. Bull., 1956, 55, 316-327. (6, 575)

Mednick, S. A. and Freedman, J. L. Stimulus generalization. Psychol. Bull., 1960, 57, 169-200. $(5,19 ; 7,199 ; 7,369 ; 8,135)$

Meduna, L. J. and Abood, L. G. Studies of a new drug (Ditran) in depressive states. J. Neuropsychiat., 1959, 1, 1-3. (6, 271)

Meehl, P. E. On the circularity of the law of effect. Psychol. Bull., 1950, 47, 52-75. (6, 81)

Mello, N. K., Ervin, F., and Cobb, S. Intertectal integration of visual information in the pigeon: electro-physiological and behavioral observations. Bol. Inst. Estud. méd. Biol. (Mex.), 1963, 21, 519-533. (9, 11)

Mello, N. K. and Peterson, N. J. Behavioral evidence for color discrimination in the cat. $J$. Neurophysiol., 1964, 27, 323-333. (9, 351)

Mello, N. K. Inter-hemispheric reversal of mirrorimage oblique lines following monocular training in pigeons. Science, 1965, 148, 252-254. $(9,11 ; 9,567)$

Mello, N. K. Reply to Cumming, Siegel, and Johnson. Science, 1965, 149, 1519-1520. $(9,567)$

Mello, N. K. Interocular transfer in pigeons: a comparison of colored left-right and up-down mirror image patterns. Paper read at APA, Chicago, Sept. 1965. (9, 11; 9, 567)

Melton, A. W. The end-spurt in memorization curves as an artifact of the averaging of the individual curves. Psychol. Monogr., 1936, 47 (2, Whole No. 212). $(3,71)$

Menkhaus, I. Versuche uber einaugiges lernen und transponierenlbeim haushuhn. Z. Tierpsychol., $1957,14,210-230 .(9,11)$

Mentzer, T. L. Comparison of three methods for 
obtaining psychophysical thresholds from the pigeon. J. comp. physiol. Psychol., 1966, 61, 96-101. $(10,251)$

Metz, J. R. Conditioning generalized imitation in autistic children. J. exp. Child Psychol., 1965, 2, 389-399. (10, 405)

Meyer, D. R. The effects of differential probabilities of reinforcement on discrimination learning by monkeys. J. comp. physiol. Psychol., 1960, 53, 173-175. (7, 151)

Meyer, D. R., Cho, C., and Wesemann, A. F. On problems of conditioning discriminated leverpress avoidance responses. Psychol. Rev., 1960, 67, 224-228. (6, 393; 6, 415; 10, 461)

Meyer, D. R., Polidora, V. J., and McConnell, D. G. Effects of spatial S-R contiguity and response delay upon discriminative performance by monkeys. J. comp. physiol. Psychol., 1961, 54, 175-177. (6, 599)

Meyers, A. K. Avoidance learning as a function of several training conditions and strain differences in rats. J. comp. physiol. Psychol., 1959, 52, 381-386. (6, 415)

Meyers, B. and McCleary, R. A. Interocular transfer of a pattern discrimination in pattern deprived cats. J. comp. physiol. Psychol., 1964, 57, 16-21. (8, 147)

Meyers, W. J. and Valenstein, E. S. Animal preference for method of obtaining reinforcing brain stimulation. J. comp. physiol. Psychol., 1964, 57, 47-51. (8, 75)

Miles, C. G. and Jenkins, H. M. Overshadowing and blocking in discriminative operant conditioning. Paper read at Psychon. Soc., Chicago, Oct. 1965. $(9,377)$

Miles, R. C. The relative effectiveness of secondary reinforcers throughout deprivation and habitstrength parameters. J. comp. physiol. Psychol., 1956, 49, 126-130. (5, 543; 9, 41)

Miles, R. C. Secondary-reinforcement stimulation throughout a series of spontaneous recoveries. J. comp. physiol. Psychol., 1956, 49, 496-498. $(5,505)$

Miles, R. C. Discrimination-learning sets. In A. M. Schrier, H. F. Harlow, and F. Stollnitz (Eds.), Behavior of nonhuman primates. Vol. 1. New York: Academic Press, 1965. Pp. 51-95. (10, 3)

Miles, W. R. Immediate psychological effects. In Benox Report: an exploratory study of the biological effects of noise. Chicago: Univ. of Chicago, 1953. Ch. 11. (1, 183)

Miles, W. R. Chimpanzee behavior: removal of foreign body from companion's eye. Proc. Nat. Acad. Sci., 1963, 49, 840-843. $(9,691)$

Millenson, J. R. A further investigation of the correlation between IRT frequency and IRT reinforcement distributions. Psychon. Sci., 1964, 1, 373-374. $(8,345 ; 9,317)$
Miller, D. A. On being referred to. Science, 1966, 153, 364-366. (10, 34; 10, 184)

Miller, G. A., Galanter, E., and Pribram, K. H. Plans and the structure of behavior. New York: Holt, 1960. $(9,213)$

Miller, J. M. and Glickstein, M. Reaction time to cortical stimulation. Science, 1964, 146, 15941596. $(9,135)$

Miller, J. M., Glickstein, M., and Stebbins, W. C. Reduction of response latency in the monkey by a procedure of differential reinforcement. Psychon. Sci., 1966, 5, 177-178. (9, 135)

Miller, N. E. and Dollard, J. Social learning and imitation. New Haven: Yale Univ. Press, 1941. $(9,677 ; 10,405)$

Miller, N. E. Experimental studies of conflict. In J. McV. Hunt (Ed.), Personality and the behavior disorders. Vol. 1. New York: Ronald Press, 1944. Pp. 43-465. (5, 19; 6, 141; 7, 369; $9,703 ; 10,75)$

Miller, N. E. Theory and experiment relating psychoanalytic displacement to stimulus-response generalization. J. abnorm. soc. Psychol., 1948, 43, 155-178. (5, 511; 7, 223; 7, 369; 10, 131; 10, 395)

Miller, N. E. Studies of fear as an acquirable drive: I. Fear as motivation and fear-reduction as reinforcement in the learning of new responses. J. exp. Psychol., 1948, 38, 89-101-. (9, $421 ; 10,291$ )

Miller, N. E. Learnable drives and rewards. In S. S. Stevens (Ed.), Handbook of experimental psychology. New York: Wiley, 1951. Pp. 435472. $(5,543 ; 8,279 ; 9,267)$

Miller, N. E. Effects of drugs on motivation: the value of using a variety of measures. Ann. N.Y. Acad. Sci., 1956, 65, 318-333. (5, 105; 5, 259)

Miller, N. E. Experiments on motivation. Science, $1957,126,1271-1278 .(5,105 ; 6,525)$

Miller, N. E. Central stimulation and other new approaches to motivation and reward. Amer. Psychologist, 1958, 13, 100-108. (2, 43)

Miller, N. E. Liberalization of basic S-R concepts: extensions to conflict behavior, motivation and social learning. In S. Koch (Ed.), Psychology: a study of a science. Vol. 2. General systematic formulations, learning, and special processes. New York: McGraw-Hill, 1959. Pp. 196-292. $(4,251 ; 5,19 ; 7,369 ; 10,75)$

Miller, N. E. Learning resistance to pain and fear: effects of overlearning, exposure, and rewarded exposure in context. J. exp. Psychol., $1960,60,137-145 .(9,251 ; 9,521 ; 10,95)$

Miller, N. E. and Barry, H. Motivational effects of drugs: methods which illustrate some general problems in psychopharmacology. Psychopharmacologia, 1960, 1, 169-199. (7, 293)

Miller, N. E. Some recent studies of conflict be- 
havior and drugs. Amer. Psychologist, 1961, 16, 12-24. $(5,19)$

Miller, N. E. and DeBold, R. C. Classically conditioned tongue-licking and operant bar pressing recorded stimultaneously in the rat. J. comp. physiol. Psychol., 1965, 59, 109-111. (9, 143)

Miller, N. E., Trowill, J., DiCara, L., Carmona, A., and Banuazizi, A. Extending the domain of learning. Science, 1966, 152, 676. (Abstract) (10, 119)

Miller, R. E., Murphy, J. V., and Mirsky, I. A. The effects of chlorpromazine on fear-motivated behavior in rats. J. Pharmacol. exp. Therap., 1957, 120, 379-387. (6, 213)

Miller, R. E. and Ogawa, N. The effect of adrenocorticotrophic hormone (ACTH) on avoidance conditioning in the adrenalectomized rat. $J$. comp. physiol. Psychol., 1962, 55, 211-213. (10, $555)$

Mintz, D. E. Force of response during ratio reinforcement. Science, 1962, 138, 516-517. $(9,627)$

Mitchell, W. G. Differentiation of activity of three mouse strains with magnetic pickup apparatus. Science, 1959, 130, 455. (8, 215)

Moelis, I. An evaluation of the effects of spreading cortical depression on motor aspects of performance. Doctoral dissertation, Univ. Illinois, 1963. $(10,193)$

Moltz, H. and Rosenblum, L. A. Imprinting and associative learning: the stability of the following response in Peking ducks (Anas platyrhyncous). J. comp. physiol. Psychol., 1958, 51, 580-583. (10, 495)

Moltz, H., Rosenblum, L., and Halikas, N. Imprinting and level of anxiety. J. comp. physiol. Psychol., 1959, 52, 240-244. (9, 177)

Moltz, H. Imprinting: empirical basis and theoretical significance. Psychol. Bull., 1960, 57, 291314. $(9,177)$

Montgomery, K. C. Exploratory behavior as a function of "similarity" of stimulus situations. $J$. comp. physiol. Psychol., 1953, 46, 129-133. (1, 341)

Montgomery, K. C. and Monkman, J. A. The relation between fear and exploratory behavior. J. comp. physiol. Psychol., 1955, 48, 132-136. $(1,341)$

Montgomery, K. C. The relation between fear induced by novel stimulation and exploratory behavior. J. comp. physiol. Psychol., 1955, 48, 254-260. $(1,341)$

Mook, D. G. Oral and postingestional determinants of the intake of various solutions in rats with esophageal fistulas. J. comp. physiol. Psychol., 1963, 56, 645-659. (10, 571)

Morgan, C., Stellar, E., and Johnson, O. Food deprivation and hoarding in rats. J. comp. physiol. Psychol., 1943, 35, 275-296. (3, 154)

Morgan, J. J. B. The overcoming of distraction and other resistances. Arch. Psychol., N.Y., 1916, No. 135. (1, 183)

Morse, W. H. An analysis of responding in the presence of a stimulus correlated with periods of non-reinforcement. Doctoral dissertation, Harvard, 1955. (1, 31; 3, 49; 4, 107; 4, 171; 4, $179 ; 4,365 ; 5,543 ; 6,1 ; 6,507)$

Morse, W. H. and Herrnstein, R. J. The maintenance of avoidance behavior using the removal of a conditioned positive reinforcer as the aversive stimuli. Amer. Psychologist, 1956, 11, 430. (Abstract) $(6,1 ; 6,423 ; 8,329 ; 9,487)$

Morse, W. H. and Herrnstein, R. J. Effects of drugs on characteristics of behavior maintained by complex schedules of intermittent positive reinforcement. Ann. N. Y. Acad. Sci., $1956,65,303-317$. (1, 73; 1, 293; 1, 359; 2, 1; 3,$49 ; 3,293 ; 5,73 ; 5,105 ; 6,125 ; 6,549 ; 9$, $389 ; 10,485$ )

Morse, W. H. and Skinner, B. F. A second type of superstition in the pigeon. Amer. J. Psychol., 1957, 70, 308-311. (2, 151; 2, 307; 3, 143; $4,187 ; 5,61 ; 5,279 ; 6,101 ; 6,507)$

Morse, W. H. and Skinner, B. F. Properties of behavior paced by an external stimulus. Paper read at EPA, New York, April 1957. (2, 133)

Morse, W. H. Some factors determining the behavioral effect of chlorpromazine. Pharmacologist, 1960, 2, 71. (6, 125)

Morse, W. H. Effect of amobarbital and chlorpromazine on punished behavior in the pigeon. Psychopharmacologia, 1964, 6, 286-294. (10, $109 ; 10,565)$

Morse, W. H. Intermittent reinforcement. 'In W. K. Honig (Ed.), Operant behavior: areas of research and application. New York: AppletonCentury-Crofts, 1966. Pp. 52-108. (10, 175; 10, $341 ; 10,425)$

Morse, W. H. and Kelleher, R. T. An interlocking shock-postponement schedule in the squirrel monkey. Paper read at EPA, New York, April 1966. (10, 451)

Mosteller, F. and Bush, R. R. Selected quantitative techniques. In G. Lindzey (Ed.), Handbook of social psychology. Vol. 1. Cambridge: AddisonWesley, 1954. Pp. 289-334. (5, 279; 10, 319)

Mostofsky, D. I., Shurtleff, D. A., and Margolius, G. Comparative sensitivity of rats and humans to changes in auditory click rate. J. comp. physiol. Psychol., 1964, 58, 436-440. (8, 47)

Motorola. Silicon zener diode handbook. Franklin Pk., Ill.: Motorola, 1959. (10, 373)

Mowrer, O. H. A stimulus-response analysis of anxiety and its role as a reinforcing agent. Psychol. Rev., 1939, 46, 553-565. (10, 291)

Mowrer, O. H. An experimental analogue of "regression" with incidental observations on reaction-formation. J. abnorm. soc. Psychol., $1940,35,56-87 .(6,47 ; 10,311)$ 
Mowrer, O. H. Anxiety-reduction and learning. $J$. exp. Psychol., 1940, 27, 497-516. (10, 131; 10, 291)

Mowrer, O. H. and Lamoreaux, R. R. Avoidance conditioning and signal duration-a study of secondary motivation and reward. Psychol. Monogr., 1942, 54 (5, Whole No. 247). (9, 421)

Mowrer, O. H. and Jones, Helen M. Extinction and behavior variability as functions of effortfulness of task. J. exp. Psychol., 1943, 33, 369. 386. $(8,1 ; 9,191)$

Mowrer, O. H. and Jones, H. Habit strength as a function of the pattern of reinforcement. J. exp. Psychol., 1945, 35, 293-311. (4, 133; 7, $91 ; 9,41)$

Mowrer, O. H. and Lamoreaux, R. R. Fear as an intervening variable in avoidance conditioning. J. comp. Psychol., 1946, 39, 29-50. (9, 421; 10, 131)

Mowrer, O. H. and Vick, P. An experimental analogue of fear from a sense of helplessness. J. abnorm. soc. Psychol., 1948, 43, 193-200. $(10,131)$

Mowrer, O. H., Palmer, Florence, and Sanger, Marjorie D. Individual learning and "racial experience" in the rat, with special reference to vocalization. J. genet. Psychol., 1948, 73, 2943. $(5,383)$

Mowrer, O. H. and Solomon, L. N. Contiguity vs drive-reduction in conditioned fear: the proximity and abruptness of drive reduction. Amer. J. Psychol., 1954, 67, 15-25. (8, 279)

Mowrer, O. H. and Aiken, E. G. Contiguity vs drive-reduction in conditioned fear: temporal variations in conditioned and unconditioned stimulus. Amer. J. Psychol., 1954, 67, 26-38. (8, 279)

Mowrer, O. H. and Keehn, J. D. How are intertrial "avoidance" responses reinforced? Psychol. Rev., 1958, 65, 209-221. (6, 47; 6, 477; 7, 315; 10, 551)

Mowrer, O. H. Learning theory and behavior. New York: Wiley, 1960. (5, 391; 5, 543; 7, 401; 8, $31 ; 9,267$ )

Mueller, C. G. Theoretical relationships among some measures of conditioning. Proc. Nat. Acad. Sci., 1950, 36, 123-130. (1, 45; 6, 237; $8,9 ; 8,131 ; 8,347 ; 9,581)$

Muenzinger, K. F. Plasticity and mechanization of the problem box habit in guinea pigs. $J$. comp. Psychol., 1928, 8, 45-69. (2, 219)

Muenzinger, K. F. and Mize, R. H. The sensitivity of the white rat to electric shock: threshold and skin resistance. J. comp. Psychol., 1933, 15, 139-148. $(1,145)$

Muenzinger, K. F. Motivation in learning: I. Electric shock for correct responses in the visual discrimination habit. J. comp. Psychol., 1934, 17, 267-277. (3, 123; 4, 225)
Muller, E. E., Loeffel, R., and Mead, S. Skin impedance in relation to pain threshold testing by electrical means. J. appl. Physiol., 1953, 5, 746-752. (5, 535)

Munn, N. L. Handbook of psychological research on the rat. Boston: Houghton Mifflin, 1950. (8, $161 ; 9,1)$

Muntz, W. R. A. Interocular transfer in Octopus vulgaris. J. comp. physiol. Psychol., 1961, 54, 49-55. $(8,147 ; 9,11)$

Muntz, W. R. A. Stimulus generalization following monocular training in octopus. J. comp. physiol. Psychol., 1962, 55, 535-540. (9, 11)

Murphy, J. V. and Miller, R. E. The effect of adrenocorticotrophic hormone (ACTH) on avoidance conditioning in the rat. J. comp. physiol. Psychol., 1955, 48, 47-49. (10, 555)

Murphy, M. J. The differentiation of a response: an exploratory study with human subjects. Doctoral dissertation, New York Univ., 1943. $(7,211)$

Murray, E. J. and Miller, N. E. Displacement: steeper gradient of generalization of avoidance than of approach with age of habit controlled. J. exp. Psychol., 1952, 43, 222-226. (5, 19)

Myers, J. L. The effects of delay of reinforcement upon an operant discrimination in the pigeon. J. exp. Psychol., 1958, 55, 363-368. (8, 97)

Myers, J. L. Secondary reinforcements: a review of recent experimentation. Psychol. Bull., 1958, 55, 284-301. (5, 543; 8, 279; 9, 547)

Myers, K. and Poole, W. E. A study of the biology of the wild rabbit, Oryctolagus cuniculus (L.), in confined populations: III. Reproduction. Aust. J. Zool., 1962, 10, 225-267. (10, 219)

Myers, K. and Poole, W. E. Oestrous cycles in the rabbit Oryctolagus cuniculus (L.). Nature, 1962, 195, 358-359. (10, 219)

Myers, R. E. Interocular transfer of pattern discrimination in cats following section of crossed optic fibers. J. comp. physiol. Psychol., 1955, 48, 470-473. $(9,11)$

Myers, R. E. and Sperry, R. W. Interhemispheric communication through the corpus callosum. Arch. Neurol. Psychiat., 1958, 86, 298-303. (9, 11)

Myers, R. E. Interhemispheric communication through corpus callosum: limitations under conditions of conflict. J. comp. physiol. Psychol., 1959, 52, 6-9. (8, 147)

Nakao, H. Emotional behavior produced by hypothalamic stimulation. Amer. J. Physiol., 1958, 194, 411-418. (9, 401)

Napalkov, A. V. Chains of motor conditioned reactions in pigeons. Zh. vyssh. nerun. deialei nosti, 1959, 9, 615-621. (5, 543)

Napier, R. A. N. Rabbits. In W. Lane-Petter (Ed.), Animals for research: principles of breeding 
and management. New York: Academic Press, 1963. Pp. 323-364. (10, 219)

Nathanson, M. H. The central action of betaaminopropylbenzene (Benezedrine). J.A.M.A., 1937, 108, 528. (3, 293)

Nefzger, M. D. The properties of stimuli associated with shock reduction. J. exp. Psychol., 1957, 53, 184-188. $(6,75)$

Nelson, D. H. and Samuels, L. T. Method for determination of 17-hydroxycorticosteroids in blood: hydroxycorticosterone in peripheral circulation. J. clin. Endocrinol., 1952, 12, 519. $(5,353)$

Nevin, J. A. Two parameters of conditioned reinforcement in a chaining situation. J. comp. physiol. Psychol., 1964, 58, 367-373. (10, 301)

Newman, E. B. and Anger, D. The effect upon simple animal behavior of different frequencies of reinforcement. Report PLR-33, Office of the Surgeon General, 1954. (See Anger, J. exp. Psychol., 1956)

Newman, F. Stimulus generalization of angular orientation following non-differential and differential conditioning. Master's thesis, Kent State, 1963. (10, 17)

Newman, F. L. and Baron, M. R. Stimulus generalization along the dimension of angularity: a comparison of training procedures. J. comp. physiol. Psychol., 1965, 60, 59-63. (9, 377)

Nicholson, A. N. A pharmacological and behavioral study of the temporal lobe. Doctoral dissertation, Birmingham Univ., 1964. (9, 291)

Nissen, H. W. Phylogenetic comparison. In S. S. Stevens (Ed.), Handbook of experimental psy. chology. New York: Wiley, 1951. Pp. 347-386. $(4,393)$

Norman, M. F. An approach to free-responding in schedules that prescribe reinforcement probability as a function of interresponse times. J. math. Psychol., 1966, 3, 235-268. (10, 425)

Norris, K. S., Prescott, J. H., Asa-Dorian, P. V., and Perkins, P. An experimental demonstration of echolocation behavior in the porpoise, Tursiops truncatus (Montagu). Biol. Bull., 1961, 120, 163-176. $(9,535)$

Norris, K. S. Some problems of echolocation in cetaceans. In W. N. Tavolga (Ed.), Marine bioacoustics. Oxford: Pergamon Press, 1964. Pp. 317-336. $(9,535)$

North, A. J. Acquired distinctiveness of form stimuli. J. comp. physiol. Psychol., 1959, 52, 339 . 341. (5, 279)

North, A. J. and Stimmel, D. T. Extinction of an instrumental response following a large number of reinforcements. Psychol. Rep., 1960, 6, 227-234. (7, 135)

Notterman, J. M. A study of some relations among aperiodic reinforcement, discrimination train- ing and secondary reinforcement. $J$. exp. Psychol., 1951, 41, 161-169. (5, 505)

Notterman, J. M., Schoenfeld, W. N., and Bersh, P. J. Conditioned heart rate response in human beings during experimental anxiety. J. comp. physiol. Psychol., 1952, 45, 1-8. (6, 61)

Notterman, J. M. Force emission during bar pressing. J. exp. Psychol., 1959, 58, 341-347. (3, 183; 3,$289 ; 4,97 ; 4,243 ; 4,257 ; 4,317 ; 5,105 ; 5$, $299 ; 5,481 ; 6,155 ; 6,179 ; 8,1 ; 8,195 ; 8$, $219 ; 8,231 ; 8,313 ; 9,205)$

Notterman, J. M. and Mintz, D. E. Exteroceptive cueing of response force. Science, 1962, 135, 1070-1071. (7, 211)

Notterman, J. M. and Mintz, D. E. Dynamics of response. New York: Wiley, 1965. (9, 627; 10, 149)

O'Connor, N. and Hermelin, B. Speech and thought in severe subnormality. New York: Macmillan, 1963. (10, 3)

O'Kelly, L. E. and Steckle, L. C. A note on longenduring emotional responses in the rat. J. Psychol., 1939, 8, 125-131. (5, 511; 7, 223; 8, 55)

O'Kelly, L. I. The effect of preloads of water and sodium chloride on voluntary water intake in thirsty rats. J. comp. physiol. Psychol., 1954, 47, 7-13. $(9,111)$

Oldfield, R. C. Continuous recording of sensory thresholds and other psycho-physical variables. Nature, 1949, 164, 581. (6, 563)

Olds, J. and Milner, P. Positive reinforcement produced by electrical stimulation of septal area and other regions of the rat brain. J. comp. physiol. Psychol., 1954, 47, 419-427. (2, 43; 3, 93; 4, 44; 4, 213; 5, 543; 8, 171)

Olds, J. Physiological mechanisms of reward. In M. R. Jones (Ed.), Nebraska symposium on motivation, 1955. Lincoln: Univ. Nebr. Press, 1955. Pp. 79-139. (2, 43)

Olds, J. A preliminary mapping of electrical reinforcing effects in the rat brain. J. comp. physiol. Psychol., 1956, 49, 281-285. (2, 43)

Olds, J. Runway and maze behavior controlled by basomedial forebrain stimulation in the rat. J. comp. physiol. Psychol., 1956, 49, 507-512. (2, 43)

Olds, J., Killam, K. F., and Bach-y-Rita, P. Selfstimulation of the brain used as a screening method for tranquilizing drugs. Science, 1956, 124, 265-266. (2, 43)

Olds, J. Adaptive functions of paleocortex and related structures. In $\mathbf{H}$. F. Harlow and C. N. Woolsey (Eds.), Biological and biochemical bases of behavior. Madison: Univ. Wis. Press, 1958. Pp. 237-267. (2, 43)

Olds, J. Self-stimulation experiments and differentiated reward systems. In $H$. Jasper (Ed.), 
Reticular formation of the brain. Boston: Little, Brown, 1958. Pp. 671-687. (2, 43)

Olds, J. Effects of hunger and male sex hormones on self-stimulation of the brain. J. comp. physiol. Psychol., 1958, 51, 320-324. (10, 571)

Olds, J. Satiation effects in self-stimulation of the brain. J. comp. physiol. Psychol., 1958, 51, 675678. $(7,183 ; 10,571)$

Olds, J. Self-stimulation of the brain. Science, 1958, 127, 315-324. (2, 43; 4, 213)

Olds, J. Studies of neuropharmacologicals by electrical and chemical manipulation of the brain in animals with chronically implanted electrodes. In P. B. Bradley, P. Deniker, and C. Radouco-Thomas (Eds.), Proc. First int. Congr. Neuro-psychopharmacol. Vol. 1. Princeton: Elsevier, 1959. Pp. 20-32. (5, 259)

Olds, J. Differential effects of drive and drugs on self-stimulation at different brain sites. In D. E. Sheer (Ed.), Electrical stimulation of the brain. Austin: Univ. Texas Press, 1961. Pp. 350-366. (10, 571)

Olds, J. Hypothalamic substrates of reward. Physiol. Rev., 1962, 42, 554-604. (8, 75; 9, 227; 10, 571)

Oomura, Y., Kimura, K., Ooyama, H., Maeno, T., Iki, M., and Kuniyoshi, M. Reciprocal activities of the ventromedial and lateral hypothalamic areas of rats. Science, 1964, 143, 484485. (10, 571)

Oomura, Y., Ooyama, H., Yamamoto, T., and Naka, F. Reciprocal relationship of the lateral and ventromedial hypothalamus in the regulation of food intake. Physiol. Behav., 1967, 2, 97-115. (10, 571)

Osgood, C. E. Method and theory in experimental psychology. New York: Oxford Univ. Press, 1953. (5, 543)

Owen, R. P. Forming accurate dividers with nonprecise resistors. Electronics, 1965, 38, No. 20, 100. $(10,207)$

Owens, Olga and Gantt, W. H. Does the presence of a person act on cardiac rate of the dog as unconditioned stimulus? Amer. J. Physiol., 1950, 163, 740. (Abstract) $(2,288)$

Padgett, C. A. and Ivey, W. D. Coturnix quail as a laboratory animal. Science, 1959, 129, 267268. $(5,265)$

Paintal, A. A. A study of gastric stretch receptors: their role in the peripheral mechanism of satiation of hunger and thirst. J. Physiol., 1954, 126, 255-270. (10, 571)

Palermo, D. S. Thumbsucking: a learned response. Pediatrics, 1956, 17, 392-399. (5, 525)

Parkinson, C. N. Parkinson's law. Boston: Houghton Mifflin, 1957. $(5,175)$

Parks, E. R. The orientation reaction as a medi- ator in sensory preconditioning. Doctoral dissertation, Univ. Nebraska, 1963. $(7,261)$

Parriss, J. R. A technique for testing the cat's discrimination of differently oriented rectangles. Nature, 1964, 202, 771-773. (9, 11)

Patrikiou, V. D. and Keehn, J. D. The effect of partial satiation on pauses after reinforcements scheduled on alternating fixed ratios. Psychon. Sci., 1964, 1, 79-80. (8, 161; 10, 185)

Pavlov, I. P. Conditioned reflexes. (Tr. G. V. Anrep.) London: Oxford Univ. Press, 1927. $(1,303 ; 2,23 ; 2,307 ; 4,57 ; 4,171 ; 4,289$; 5,$511 ; 5,543 ; 6,1 ; 6,131 ; 6,141 ; 6,343 ; 6$, $477 ; 7,173 ; 8,263 ; 9,191 ; 9,249 ; 9,305 ; 10$, $17 ; 10,243 ; 10,535 ; 10,545$ )

Pavlov, I. P. Lectures on conditioned reflexes. (Tr. by W. H. Gantt.) New York: Liveright, 1928. $(5,209 ; 10,45)$

Payne, W. H. Comparison of sensitivity of psychophysical and electrophysiological measures of scotopic thresholds in the vicinity of the blind spot. Percept. Psychophys., 1967, 2, 128. 130. $(10,541)$

Peacock, L. J. and Williams, M. An ultrasonic device for recording activity. Amer. J. Psychol., $1963,56,814-820$. (8, 215)

Peirce, J. T. and Nuttall, R. Durations of sexual contact in the rat. J. comp. physiol. Psychol., 1961, 54, 584-587. (10, 219)

Pellmont, B., Steiner, F. A., Besendorf, H., Bachtold, H. P., and Laüppi, E. Einfuhrüng in die Pharmakologie von Taractan, einem Neurolepticum mit besonderem Wirkungscharakter. Schweiz. med. Wchnschr., 1960, 90, 598-599. (9, 243)

Penfield, W. and Jasper, H. Epilepsy and the functional anatomy of the brain. Boston: Little, Brown, 1954. (2, 43)

Pereboom, A. C. An analysis and revision of Hull's theorem 30. J. exp. Psychol., 1957, 53, 234-238. $(10,417)$

Pereboom, A. C. and Crawford, B. M. Instrumental and competing behavior as a function of trials and reward magnitude. J. exp. Psychol., 1958, 56, 82-85. (5, 481; 9, 671)

Perin, C. T. Behavior potentiality as a joint function of the amount of training and the degree of hunger at the time of extinction. $J$. exp. Psychol., 1942, 30, 93-113. (1, 221; 4, 133; 4, 317; 7,$135 ; 8,243$ )

Perin, C. T. The effect of delayed reinforcement upon the differentiation of bar responses in white rats. J. exp. Psychol., 1943, 32, 95-109. $(3,275 ; 10,67)$

Perkins, C. C. The relation of secondary reward to gradients of reinforcement. J. exp. Psychol., 1947, 37, 377-392. (8, 97)

Perkins, C. C., Jr. and Weyant, R. G. The interval between training and test trials as a deter- 
miner of the slope of generalization gradients. J. comp. physiol. Psychol., 1958, 51, 596-600. $(3,9)$

Persson, N. Self-stimulation in the goat. Acta Physiol. Scand., 1962, 55, 276-285. (7, 263)

Peters, J. E. and Gantt, W. H. Conditioning of human heart rate to graded degrees of muscular tension. Fed. Proc., 1951, 10, 104. (6, 61)

Petersén, I. and Kugelberg, E. Duration and form of action potential in the normal human muscle. J. Neurol. neurosurg. Psychiat., 1949, 12, 124-128. $(9,69)$

Peterson, G. E. and McKinney, N. P. The measurement of speech power. Phonetica, 1961, 7, 65. 84. $(6,179 ; 7,107)$

Peterson, J. C. A new device for teaching, testing, and research in learning. Trans. Kansas Acad. Sci., 1930, 33, 41-47. (5, 541)

Peterson, N. Control of behavior by presentation of an imprinted stimulus. Science, 1960, 132, 1395-1396. (8, 171;9, 177; 10, 495)

Peterson, N. Effect of monochromatic rearing on the control of responding by wavelength. Science, 1962, 136, 774-775. $(7,199 ; 9,351 ; 10,17)$

Picciolo, A. R. Sexual and nest discrimination by species of Colisa and Trichogaster. Doctoral dissertation, Univ. Maryland, 1961. (7, 45)

Pickering, D. E. and Kao, T. T. Fluid and electrolyte therapy for monkeys. J. Amer. Vet. Med. Assn., 1961, 138, 527-531. (6, 249)

Pines, G., Miller, H., and Alles, G. A. Clinical observations on phenylaminoethanol sulfate. J.A.M.A., 1930, 94, 790-791. (3, 293)

Polyak, S. The vertebrate visual system. Chicago: Univ. Chicago Press, 1957. (6, 627; 7, 361)

Porter, D. A critical review of a portion of the literature on teaching devices. Harv. educ. Rev., 1957, 27, 126-147. (5, 33)

Porter, P. B., Stone, C. P., and Ericksen, C. W. Learning ability in rats given electro-convulsive shocks in late infancy. J. comp. physiol. Psychol., 1948, 41, 144-154. (2, 335)

Porter, R. W., Brady, J. V., Conrad, D. G., and Mason, J. W. Occurrence of gastrointestinal lesions in behaviorally conditioned and intracerebral self-stimulated monkeys. Fed. Proc., 1957, 16, 101-102. (1, 69)

Postman, L. The history and present status of the law of effect. Psychol. Bull., 1947, 44, 489-563. $(8,385)$

Powell, D. R. and Thomas, C. C. Strength of secondary reinforcement as a determiner of the effects of duration of goal responses on learning. J. exp. Psychol., 1957, 53, 106-112. (5, 543)

Powell, E. A rapid method of intracranial electrode localization using unstained frozen sections. EEG clin. Neurophysiol., 1964, 17, 432-434. (10, 277)

Premack, Ann J. and Premack, D. Increments in ad libitum eating as a function of deprivation for wheel-turning behavior. Paper read at MPA, Detroit, May 1958. (5, 89)

Premack, D., Collier, G. and Roberts, C. L. Frequency of light-contingent bar pressing as a function of the amount of light deprivation. Paper read at APA, New York, Sept. 1957. (2, 127)

Premack, D. Deprivation-performance function for light-contingent bar pressing as determined by the number of consecutive tests per deprivation interval. Paper read at MPA, Detroit, May 1958. (2, 127)

Premack, D. Toward empirical behavior laws: I. Positive reinforcement. Psychol. Rev., 1959, 66, 219-233. (5, 89; 5, 105; 5, 543; 6, 81; 6, 544; $7,27 ; 7,91 ; 8,357 ; 9,19 ; 10,461)$

Premack, D. Predicting instrumental performance from the independent rate of the contingent response. J. exp. Psychol., 1961, 61, 163-171. $(5,105 ; 6,81 ; 7,91)$

Premack, D. and Collier, G. Analysis of nonreinforcement variables affecting response probability. Psychol. Monogr., 1962, 76 (5, Whole No. 524). (5, 89; 5, 105; 6, 81; 6, 209; 7, 91)

Premack, D. Reversibility of the reinforcement relation. Science, 1962, 136, 255-257. (5, 89; 6, $81 ; 7,91)$

Prescott, R. G. W. Estrous cycle in the rat: effects on self-stimulation behavior. Science, 1966, 152, 796-797. (10, 571)

Pressey, S. L. Simple apparatus which gives tests and scores and teaches. Sch. and Soc., 1926, 23, 373-376. $(3,275)$

Prinzmetal, M. and Alles, G. A. The central nervous system stimulant effects of dextro-amphetamine sulphate. Amer. J. med. Sci., 1940, 200, 665-673. (3, 293)

Prokasy, W. F. The acquisition of observing responses in the absence of differential external reinforcement. J. comp. physiol. Psychol., 1956, 49, 131-134. (5, 3; 5, 543)

Psychopharmacology Service Center. A selective list of drugs used in psychiatry. Bethesda, Md.: NIMH, 1962. $(6,271)$

Pubols, B. H. Incentive magnitude, learning, and performance in animals. Psychol. Bull., 1960, 57, 89-115. (4, 125; 10, 375)

Pubols, B. H. Constant versus variable delay of reinforcement. J. comp. physiol. Psychol., 1962, 55, 52-56. (10, 35)

Puckle, O. S. (Ed.) Time bases. (2nd ed.) New York: Wiley, 1951, $(4,85)$

Pumphrey, R. J. Sensory organs: vision. In A. J. Marshall (Ed.), The biology and comparative physiology of birds. Vol. 2. New York: Academic Press, 1961. Pp. 55-68. (7, 361)

Raben, M. W. The white rat's discrimination of 
differences in intensity of illumination as measured by a running response. J. comp. physiol. Psychol., 1949, 42, 254-272. (1, 303; 6, 1)

RAND Corp. $A$ million random digits. Glencoe, Ill.: Free Press, 1955. (10, 57)

Randall, L. O. Toxicology of Marsilid. J. clin. exp. Psychopath. \& Quart. Rev. Psychiat. Neurol., 1957, 19 (Spec. Suppl.), 178-182. (2, 271)

Ratliff, F. Mach bands: quantitative studies on neural networks in the retina. San Francisco: Holden-Day, 1965. (10, 243)

Ratner, S. C. Effect of extinction of dipper-approaching on subsequent extinction of barpressing and dipper-approaching. J. comp. physiol. Psychol., 1956, 49, 576-581. (5, 543)

Ratner, S. C. Reinforcing and discriminative properties of the click in a Skinner box. Psychol. Rep., 1956, 2, 332. (5, 543)

Ratner, S. C. Hypnotic reactions of rabbits. Psychol. Rep., 1958, 4, 209-210. (9, 63)

Ray, B. A. The course of acquisition of a line tilt discrimination by rhesus monkeys. Doctoral dissertation, Columbia, 1966. (10, 17)

Ray, O. S. Tranquilizer effects on conditioned suppression. Psychopharmacologia, 1964, 5, 136146. (10, 565)

Ray, O. S. and Emley, G. Time factors in interhemispheric transfer of learning. Science, 1964, 144, 76-78. (10, 193)

Razran, G. Studies in configural conditioning: VI. Comparative extinction and forgetting of pattern and of single-stimulus conditioning. J. exp. Psychol., 1939, 24, 432-438. (6, 575; 9, 659)

Razran, G. Stimulus generalization of conditioned responses. Psychol. Bull., 1949, 46, 337-365. (6, $1 ; 6,343$ )

Razran, G. Avoidant vs unavoidant conditioning and partial reinforcement in Russian laboratories. Amer. J. Psychol., 1956, 69, 127-129. (9, 421)

Razran, G. The observable unconscious and the inferable conscious in current Soviet psychophysiology: interoceptive conditioning, semantic conditioning, and the orienting reflex. Psychol. Rev., 1961, 68, 81-147. (5, 543; 8, 405; 10, 119)

Reed, J. D. Spontaneous activity of animals. Psychol. Bull., 1947, 44, 393-412. (6, 473)

Reid, L. S. The development of noncontinuity behavior through continuity learning. J. exp. Psychol., 1953, 46, 107-112. (3, 275)

Reid, R. L. Discrimination-reversal learning in pigeons. J. comp. physiol. Psychol., 1958, 51, 716-720. (4, 133; 6, 1; 10, 159)

Reinhold, D. B. and Perkins, C. C. Stimulus generalization following different methods of training. J. exp. Psychol., 1955, 49, 423-428. $(10,17)$
Remmen, E., Cohen, S., Ditman, K. S., and Frantz, J. R. Psychochemotherapy: the physicians' manual. Los Angeles: West. Med. Pub. 1962. $(9,243)$

Restle, F. Toward a quantitative description of learning set data. Psychol. Rev., 1958, 65, 77-91. (3, 247)

Revusky, S. H. Some effects of hunger and frequency of reinforcement on timing. Doctoral dissertation, Indiana, 1961. (6, 163; 10, 319)

Revusky, S. H. Mathematical analysis of the durations of reinforced inter-response times during variable interval reinforcement. Psychometrika, 1962, 27, 307-314. (6, 163; 6, 437; 9, 87)

Rey, A. Les conduites conditionees du cobaye. Arch. Psychol., Genève, 1936, 25, 217-312. (2, 219)

Reynolds, G. S. An analysis of interactions in a multiple schedule. Doctoral dissertation, Harvard, 1960. $(4,57 ; 4,107 ; 4,179 ; 8,269)$

Reynolds, G. S. and Catania, A. C. Response rate as a function of rate of reinforcement and probability of reinforcement in variable-interval schedules. Paper read at Psychon. Soc., New York, Oct. 1961. (6, 1; see also Catania and Reynolds, 1963)

Reynolds, G. S. and Catania, A. C. Temporal discriminations in pigeons. Science, 1962, 135, 314-315. (7, 415;9, 1;9, 65)

Reynolds, G. S. Potency of conditioned reinforcers based on food and on food and punishment. Science, 1963, 139, 838-839. (7, 179; 10, 35; 10, 87)

Reynolds, R. W. The relationship between stimulation voltage and rate of hypothalamic selfstimulation in the rat. J. comp. physiol. Psychol., 1958, 51, 193-198. (7, 285; 8, 75)

Rheingold, Harriet L., Gewirtz, J. L., and Ross, Helen W. Social conditioning of vocalization in the infant. J. comp. physiol. Psychol., 1959, 52, 68-73. $(4,171 ; 4,233)$

Rheingold, Harriet L., Stanley, W. C., and Doyle, G. A. Visual and auditory reinforcement of a manipulatory response in the young child. $J$. exp. child Psychol., 1964, 1, 316-326. (9, 105)

Rice, G. E. and Gainer, P. "Altruism" in the albino rat. J. comp. physiol. Psychol., 1962, 55, 123-125. $(9,691)$

Richter, C. P. Animal behavior and internal drives. Quart. Rev. Biol., 1927, 2, 307-343. (6, 209)

Richter, C. P. Domestication of the Norway rat and its implications for the problem of stress. Proc. Assn. Res. nerv. ment. dis., 1950, 29, 19. $(5,511)$

Riesen, A. H. The development of visual perception in man and chimpanzee. Science, 1947, 106, 107-108. (1, 87)

Riess, B. F. Limits of learning ability in the white 
rat and the guinea pig. Genet. Psychol. Monogr., 1934, 15, 303-368. (6, 271)

Rilling, M. and McDiarmid, C. Signal detection in fixed-ratio schedules. Science, 1965, 148, 526527. $(9,1)$

Riopelle, A. J. Transfer suppression and learning sets. J. comp. physiol. Psychol., 1953, 46, 108114. $(2,335)$

Roberts, E. Thumb and finger-sucking in relation to feeding in early infancy. Amer. J. Dis. Child., 1944, 68, 7-8. (5, 525)

Roberts, W. A., Bullock, D. H., and Bitterman, M. E. Resistance to extinction in the pigeon after partially reinforced instrumental training under discrete-trials conditions. Amer. J. Psychol., 1963, 76, 353-365. (6, 301)

Roberts, W. W. and Kiess, H. O. Motivational properties of hypothalamic aggression in cats. J. comp. physiol. Psychol., 1964, 58, 187-193. $(9,191)$

Robinson, E. S. and Brown, M. A. Effect of serial position upon memory. Amer. J. Psychol., 1926, 37, 538-552. $(5,15)$

Robinson, J. S. The sameness-difference discrimination problem in chimpanzees. J. comp. physiol. Psychol., 1955, 48, 195-197. (1, 87)

Rocha e Silva, M. Fundamentos de Farmacologia. Rio de Janeiro: Livraria Editora Guanabara, Koogan S. A., 1961. (6, 91)

Rock, I. The role of repètition in associative learning. Amer. J. Psychol., 1957, 70, 186-193. $(5,15)$

Rohles, F. H., Belleville, R. E., and Grunzke, M. E. The measurement of higher intellectual functioning in the chimpanzee. Aerospace Med., 1961, 32, 121-125. (4, 323)

Rohles, F. H., Grunzke, M. E., and Reynolds, H. H. Chimpanzee performance during the ballistic and orbital Project Mercury flights. J. comp. physiol. Psychol., 1963, 56, 2-10. (6, 549)

Rohles, F. H., Grunzke, M. E., and Belleville, R. E. Performance aspects of the MR-2 flight. In J. P. Henry and J. D. Mosely (Eds.), Results of the Project Mercury ballistic and orbital chimpanzee flights, NASA SP-39. Washington, D.C.: Office of Scientific and Technical Information, NASA, 1963. Pp. 21-24. (6, 549)

Rohles, F. H., Grunzke, M. E. and Reynolds, H. H. Performance aspects of the MA-5 flight. In J. P. Henry and J. D. Mosely (Eds.), Results of the Project Mercury ballistic and orbital chimpanzee flights, NASA SP-39. Washington, D.C.: Office of Scientific and Technical Information, NASA, 1963. Pp. 39-52. (6, 549)

Rosenbaum, G. Stimulus generalization as a function of level of experimentally induced anxiety. J. exp. Psychol., 1953, 45, 35-43. (5, 19)

Rosenberg, P. The further use of amphetamine (Benzedrine) sulfate and dextro-amphetamine in the treatment of obesity. Med. World., 1942, 60, 210-212 and 227. $(3,293)$

Rosenthal, $R$. On the social psychology of the psychological experiment: the experimenter's hypothesis as unintended determinant of experimental results. Amer. Scientist, 1963, 51, 268-283. (8, 261)

Ross, S. and Ross, J. G. Social facilitation of feeding behavior in dogs: I. Group and solitary feeding. J. genet. Psychol., 1949, 74, 97-108. $(10,387)$

Ross, S. and Ross, J. G. Social facilitation of feeding behavior in dogs: II. Feeding after satiation. J. genet. Psychol., 1949, 74, 293-304. (10, 387)

Rousey, C. L. Stuttering severity during prolonged spontaneous speech. J. speech hear. Res., 1958, 1, 40-47. (1, 173)

Roush, R. G. and Urbanski, E. T. Universal medical timer and pulse stimulator. Electronics, 1953, 26, Nov., 154-157. (9, 501)

Routledge, C. O. and Kelleher, R. T. Interactions between the effects of methamphetamine and pentobarbital on operant behavior in the pigeon. Psychopharmacologia, 1965, 7, 400408. $(10,485)$

Rowe, R. P., Bloom, B. M., P'an, S. Y., and Finger, K. The pharmacological characterization of the antidepressant, nialamide. Fed. Proc., 1959, 18, 441. $(2,271)$

Rowell, C. H. F. Displacement grooming in the chaffinch. Animal Behav., 1961, 9, 38-63. (7, 351)

Ruch, T. C. Diseases of laboratory primates. Philadelphia: Saunders, 1959. (6, 249)

Rudel, R. G. and Teuber, H. L. Discrimination of direction of line in children. J. comp. physiol. Psychol., 1963, 56, 892-898. (9, 11; 9, 567)

Rusinov, V. S. and Rabinovich, M. Y. Electroencephalographic researches in the laboratories and clinics of the Soviet Union. EEG clin. Neurophysiol., 1958 (Suppl. 8). (5, 467)

Russell, I. S. Analysis of responding during operant discrimination. Doctoral dissertation, Indiana, 1961. $(6,75)$

Russell, I. S. and Ochs, S. Localization of a memory trace in one cortical hemisphere and transfer to the other hemisphere. Brain, 1963, 86, 37-54. $(7,350 ; 10,193)$

Ryder, J. D. Electronic fundamentals and applications. New York: Prentice-Hall, 1950. (8, 339)

Saltzman, I. J. Maze learning in the absence of primary reinforcement: a study of secondary reinforcement. J. comp. physiol. Psychol., 1949, 42, 161-173. (5, 543)

Salzinger, K. Experimental manipulation of verbal 
behavior: a review. J. gen. Psychol., 1959, 61, 65-94. $(5,383)$

Salzinger, S., Salzinger, K., Portnoy, S., Eckman, J., Bacon, P. M., Deutsch, M., and Zubin, J. Operant conditioning of continuous speech in young children. Child Develpm., 1962, 33, 683695. $(7,139)$

Sandler, J. Reinforcement combinations and masochistic behavior: a preliminary report. Psychol. Rep., 1962, 11, 110. (7, 409)

Sarton, G. The history of science and the new humanism. Bloomington: Ind. Univ. Press, 1962. $(9,163)$

Saslow, G. and Matarazzo, J. D. A technique for studying changes in interview behavior. In $\mathrm{E}$. A. Rubenstein and M. B. Parloff (Eds.), Research in psychotherapy. Washington, D.C.: APA, 1959. Pp. 125-159. (7, 99)

Sauer, R. M. and Fegley, H. C. The role of infectious and non-infectious diseases in monkey health. Ann. N.Y. Acad. Sci., 1960, 85, 855-888. $(6,249)$

Sawrey, W. L. and Weisz, J. D. An experimental method of producing gastric ulcers. J. comp. physiol. Psychol., 1956, 49, 269-270. (10, 131)

Sawrey, W. L., Conger, J. J., and Turrell, E. S. An experimental investigation of the role of psychological factors in the production of gastric ulcers in rats. J. comp. physiol. Psychol., 1956, 49, 457-461. (1, 69)

Schaeffer, R. W. and Premack, D. Licking rates in infant albino rats. Science, 1961, 134, 19801981. $(10,495)$

Schein, M. W. and Hale, E. B. Stimuli eliciting sexual behavior. In F. A. Beach (Ed.), Sex and behavior. New York: Wiley, 1965. Pp. 440482. $(10,219)$

Schevill, W. E. and Lawrence, Barbara. Auditory response of a bottlenosed porpoise, Tursiops truncatus, to frequencies above $100 \mathrm{kc}$. J. exp. Zool., 1953, 124, 147-165. (9, 535)

Schevill, W. E. and Lawrence, Barbara. Food-finding by a captive porpoise (Tursiops truncatus). Brevoria, 1956, No. 53. (9, 535)

Schlosberg, $\mathrm{H}$. Conditioned responses in the white rat. J. genet. Psychol., 1934, 45, 303-335. (9, 421)

Schlosberg, H. and Katz, A. Double alternation lever pressing in the white rat. Amer. J. Psychol., 1943, 56, 274-282. (8, 161)

Schlosberg, H. and Solomon, R. L. Latency of response in a choice discrimination. $J$. exp. Psychol., 1943, 33, 22-39. (1, 303; 2, 319; 5, 487; 6,$1 ; 10,3 ; 10,17$ )

Schmidt, H., Moak, S. J., and Van Meter, W. G. Atropine depression of food and water intake. Amer. J. Physiol., 1958, 192, 543-545. (2, 107)

Schneider, A. M. and Hamburg, M. Interhemispheric transfer with spreading depression: a memory transfer or stimulus generalization phenomenon? J. comp. physiol. Psychol., 1966, 62, 133-136. (10, 193)

Schneider, A. M. Retention under spreading depression: a generalization decrement phenomenon. J. comp. physiol. Psychol., 1966, 62, 317319. $(10,193)$

Schneiderman, N., Fuentes, I., and Gormezano, I. Acquisition and extinction of the classically conditioned eyelid response in the albino rabbit. Science, 1962, 136, 650-652. $(9,605)$

Schoenfeld, W. N. An experimental approach to anxiety, escape, and avoidance behavior. In P. H. Hoch and J. Zubin (Eds.), Anxiety. New York: Grune \& Stratton, 1950. Pp. 70-99. (5, 41; 5,$247 ; 5,391 ; 6,477 ; 6,549 ; 7,315 ; 9,267$; $9,421 ; 9,641 ; 10,551)$

Schoenfeld, W. N., Antonitis, J. J. and Bersh, P. J. Unconditioned response rate of the white rat in a bar-pressing apparatus. J. comp. physiol. Psychol., 1950, 43, 41-48. (2, 127)

Schoenfeld, W. N., Antonitis, J. J., and Bersh, P. J. A preliminary study of training conditions necessary for secondary reinforcement. $J$. exp. Psychol., 1950, 40, 40-45. (5, 543; 6, 75; 9, 369) Schoenfeld, W. N. On the difference in resistance to extinction following regular and periodic reinforcement. CEAB Note. No. 20. (Mimeo., issued from Indiana Univ., Psychol. Dept., Bloomington, Ind., 1950.) (1, 109; 4, 243; 4,$317 ; 6,179$ )

Schoenfeld, W. N., Cumming, W. W., and Hearst, $E$. On the classification of reinforcement schedules. Proc. Nat. Acad. Sci., 1956, 42, 563570. $(1,45 ; 1,109 ; 1,245 ; 2,1 ; 2,133 ; 2,191$; 3,$49 ; 3,71 ; 4,73 ; 4,365 ; 6,265 ; 6,323 ; 6$, $361 ; 6,437 ; 6,607 ; 6,623 ; 7,125 ; 7,281 ; 7$, $391 ; 10,251$ )

Schoenfeld, W. N. and Cumming, W. W. Some effects of alternation rate in a time-correlated reinforcement contingency. Proc. Nat. Acad. Sci., 1957, 43, 349-354. (1, 45; 1, 245; 2, 1; 2, 87; $2,191 ; 3,49 ; 3,71 ; 4,73 ; 6,607 ; 7,125)$

Schoenfeld, W. N. and Cumming, W. W. Studies in a temporal classification of reinforcement schedules: summary and projection. Proc. Nat. Acad. Sci., 1960, 46, 753-758. (4, 73; 4, 243; 4, $365 ; 6,265 ; 6,623 ; 7,281$ )

Schrier, A. M. Comparison of two methods of investigating the effect of amount of reward on performance. J. comp. physiol. Psychol., 1958, 51, 725-731. (4, 133; 10, 417)

Schrier, A. M. Response latency of monkeys as a function of reward amount and trials within test days. Psychol. Rep., 1962, 10, 439-444. (10, 417)

Schuknecht, H. F. Techniques for study of cochlear function and pathology in experimental animals. A.M.A. Arch. Otolaryngol., 1953, 58, 377 397. (5, 323) 
Schulte, A. Transfer und transpositionsversuche mit monokular dressierten fischen. Z. vergl. Physiol., 1957, 39, 432-476. (9, 11)

Schuster, C. R. and Brady, J. V. The discriminative control of a food reinforced operant by interoceptive stimulation. I. P. Pavlov J. Higher Nerv. Activity, 1964, 14, 448-458. (8, 405; 10, 235)

Schusterman, R. J. Successive discrimination-reversal training and multiple discrimination training in one-trial learning by chimpanzees. J. comp. physiol. Psychol., 1964, 58, 153-156. $(9,593)$

Schusterman, R. J. Orienting responses and underwater visual discrimination in the California sea lion. Proc. Amer. Psychol. Assn. 1965, 1, 139-140. (9, 593)

Schusterman, R. J. Errorless discrimination-reversal learning in the California sea lion. Proc. Amer. Psychol. Assn., 1965, 1, 141-142. (9, 593)

Schusterman, R. J., Kellogg, W. N., and Rice, C. E. Underwater visual discrimination by the California sea lion. Science, 1965, 147, 1594-1596. $(9,593)$

Schusterman, R. J. Underwater click vocalization by a California sea lion: effects of visibility. Psychol. Rec., 1966, 16, 129-136. (9, 593)

Schwarz, B. E. and Bickford, R. G. Electroencephalographic changes in animals under the influence of hypnosis. J. nerv. ment. Dis., 1956, 124, 435-439. (9, 63)

Scott, J. P. Dominance and the frustration-aggression hypothesis. Physiol. Zool., 1948, 21, 31-39. (7, 223)

Scott, J. P. and Fredericson, E. The causes of fighting in mice and rats. Physiol. Zool., 1951, 24, 273-309. (5, 511; 9, 233)

Scott, J. P. Some effects at maturity of gentling, ignoring or shocking rats during infancy. $J$. abnorm. soc. Psychol., 1955, 51, 410-414. (2, 335)

Scott, J. P. Aggression. Chicago: Univ. Chicago Press, 1958. (8, 55; 8, 171; 10, 395)

Segal, Evalyn F. and Holloway, S. M. Timing behavior in rats with water drinking as a mediator. Science, 1963, 140, 888-889. (8, 107; 9, 37)

Segal, Evalyn F. The development of water drinking on a dry-food free-reinforcement schedule. Psychon. Sci., 1965, 2, 29-30. (9, 37)

Segal, Evalyn F., Oden, D. L., and Deadwyler, S. A. Determinants of polydipsia: IV. Free-reinforcement schedules. Psychon. Sci., 1965, 3, 11-12. $(9,337)$

Semenoff, W. A. and Young, F. A. Comparison of the auditory acuity of man and monkey. $J$. comp. physiol. Psychol., 1964, 57, 89-93. (9, 135)

Senders, V. L. Measurement and statistics. New York: Oxford Univ. Press, 1958. (6, 101)

Seward, J. P. Aggressive behavior in the rat: I.
General characteristics: age and sex differences. J. comp. Psychol., 1945, 38, 175-197. (5, 511)

Seward, J. P. Aggressive behavior in the rat: II. An attempt to establish a dominance hierarchy. J. comp. Psychol., 1945, 38, 213-224. (5, 511)

Seward, J. P. Aggressive behavior in the rat: III. The role of frustration. J. comp. Psychol., 1945, 38, 225-238. (5, 511)

Seward, J. P. Aggressive behavior in the rat: IV. Submission as determined by conditioning, extinction, and disuse. J. comp. Psychol., 1945, 39, 51-76. (5, 511)

Seward, J. P. Secondary reinforcement as tertiary motivation: a revision of Hull's revision. Psychol. Rev., 1950, 57, 362-374. (7, 401)

Seward, J. P. and Raskin, D. C. The role of fear in aversive behavior. J. comp. physiol. Psychol., 1960, 53, 328-335. (10, 131)

Seward, J. P., Shea, R. A., Uyeda, A. A., and Raskin, D. C. Shock strength, shock reduction, and running speed. J. exp. Psychol., 1960, 60, 250-254. (6, 519)

Sewell, W. R. and Kendall, S. B. A note on interresponse time distributions during generalization testing. Psychon. Sci., 1965, 3, 95-96. (10, 165)

Shaklee, A. B. Measurement of cutaneous electrical thresholds in animal research. Amer. J. Psychol., 1957, 70, 624-627. (1, 145)

Shapiro, M. M. Salivary and motor conditioning: a reply to Konorski. Science, 1961, 133, 12861287. (8, 405)

Shapiro, M. M. Respondent salivary conditioning during operant lever pressing in dogs. Science, 1960, 132, 619-620. (5, 543; 8, 405)

Shapiro, M. M. Salivation and lever pressing relationships. J. comp. physiol. Psychol., 1962, 55, 567-571. (7, 401)

Shapiro, M. M. Temporal relationship between salivation and lever pressing with differential reinforcement of low rates. J. comp. physiol. Psychol., 1962, 55, 567-571. (8, 405)

Sharma, K. N., Anand, B. K., Dua, S., and Singh, B. Role of stomach in regulation of activities of hypothalamic feeding centers. Amer. J. Physiol., 1961, 201, 593-598. (10, 571)

Sheatz, G. C. Multilead electrode holders in chronic preparations: multilead techniques for large and small animals. In D. E. Sheer (Ed.), Electrical stimulation of the brain. Austin: Univ. Texas Press, 1961. Pp. 45-50. (3, 93; 5, 467; 5, 473; 6, 61)

Sheckel, C. L. Self-adjustment of the interval in delayed matching: limit of delay for the rhesus monkey. J. comp. physiol. Psychol., 1965, 59, 415-418. (9, 249)

Sheer, D. E. (Ed.) Electrical stimulation of the 
brain. Austin: Univ. Texas Press, 1961. (7, 12)

Sheffield, F. D. Avoidance training and the contiguity principle. J. comp. physiol. Psychol., $1948,41,165-177 .(8,9 ; 10,131)$

Sheffield, F. D. and Roby, T. B. Reward value of a non-nutritive sweet taste. J. comp. physiol. Psychol., 1950, 43, 471-481. (8, 75)

Sheffield, F. D. and Temmer, H. W. Relative resistance to extinction of escape training and avoidance training. J. exp. Psychol., 1950, 40, 287-298. (6, 361)

Sheffield, F. D. and Campbell, B. A. The role of experience in the "spontaneous" activity of hungry rats. J. comp. physiol. Psychol., 1954, 47, 97-100. $(2,165)$

Sheffield, F. D., Roby, T. B., and Campbell, B. A. Drive reduction versus consummatory behavior as determinants of reinforcement. J. comp. physiol. Psychol., 1954, 47, 349-354. (8, 75)

Sheffield, F. D. Relation between classical conditioning and instrumental learning. In W. F. Prokasy (Ed.), Classical conditioning. New York: Appleton-Century-Crofts, 1965. Pp. 302322. $(7,401)$

Sheffield, V. F. Extinction as a function of partial reinforcement and distribution of practice. $J$. exp. Psychol., 1949, 39, 511-575. (1, 109)

Sheldon, I. R and Luzon, T. B. Facts and cautions for planning data communications. Cont. Engng., 1962, 9, 105-108. (9, 507)

Shelter, C. J., Barnes, H. W., and Homme, L. E. An investigation of precision timing behavior in the rat. Amer. Psychologist, 1959, 14, 421. (Abstract) (4, 299)

Shepard, R. N. Stimulus and response generalization: a stochastic model relating generalization to distance in psychological space. Psychometrika, 1957, 22, 325-345. (5, 487)

Sherman, J. G. The temporal distribution of responses on fixed interval schedules. Doctoral dissertation, Columbia, 1959. (5, 213; 6, 607)

Sherman, J. G., Hegge, F. W., and Pierrel, R. Discrimination formation as related to the amount of $S^{\Delta}$ training. Psychon. Sci., 1964, 1, 43-44. $(9,219)$

Sherrington, $\mathrm{C}$. The integrative action of the nervous system. New Haven: Yale Univ. Press, 1906 (reprinted 1947). (5, 511)

Shirkova, G. I. and Verevkina, G. L. Chains of conditioned motor reflexes in monkeys. Doklad. Akad. Nauk SSSR, 1960, 133, 730-733. (5, 543)

Shuey, A. M. The limits of learning ability in kittens. Genet. Psychol. Monogr., 1931, 10, 287-378. (6, 271)

Sidley, N. A. Two parameters of a temporally defined schedule of negative reinforcement. Doctoral dissertation, Columbia, 1962. (6, 293; 6, 361)
Sidman, M. Avoidance conditioning with brief shock and no exteroceptive "warning signal." Doctoral dissertation, Columbia, 1952. (6, 477; see also Sidman, Science, 1953)

Sidman, M. A note on functional relations obtained from group data. Psychol. Bull., 1952, 49, 263-269. (4, 133; 4, 317)

Sidman, M. Two temporal parameters of the maintenance of avoidance behavior by the white rat. J. comp. physiol. Psychol., 1953, 46, 253261. (1, 73; 1, 183; 1, 207; 1, 293; 2, 23; 2, 133; 2,$185 ; 3,35 ; 4,17 ; 4,157 ; 4,187 ; 4,275$; 4,$309 ; 4,393 ; 5,41 ; 5,97 ; 5,247 ; 5,353$; 6,$47 ; 6,361 ; 6,477 ; 6,563 ; 7,26 ; 8,31 ; 8$, $269 ; 9,227 ; 9,389 ; 9,421 ; 9,557 ; 9,641 ; 10$, $439 ; 10,551$ )

Sidman, M. Avoidance conditioning with brief shock and no exteroceptive warning signal. Science, 1953, 118, 157.158. (1, 69; 1, 73; 1, 167; 1,$207 ; 1,265 ; 1,293 ; 1,351 ; 2,185 ; 2,203$; 2,$271 ; 3,35 ; 3,155 ; 3,201 ; 3,349 ; 4,157$; 4,$187 ; 4,275 ; 4,393 ; 5,19 ; 5,41 ; 5,97$; 5,$353 ; 5,391 ; 5,467 ; 5, .473 ; 6,47 ; 6,61$; 6,$477 ; 6,507 ; 6,525 ; 6,537 ; 6,549 ; 6,621$; 7,$97 ; 7,129 ; 7,223 ; 7,315 ; 8,9 ; 8,31 ; 8$, $55 ; 8,171 ; 8,203 ; 8,269 ; 8,419 ; 9,389 ; 9$, $421 ; 9,487 ; 10,131 ; 10,291 ; 10,311 ; 10,461$; $10,555)$

Sidman, M. and Stebbins, W. C. Satiation effects under fixed-ratio schedules of reinforcement. J. comp. physiol. Psychol., 1954, 47, 114-116. $(1,109 ; 1,221 ; 1,281 ; 2,1 ; 2,301 ; 3,293$; 4,$379 ; 6,125 ; 6,473 ; 6,525 ; 7,1 ; 7,91 ; 7$, $301 ; 8,117 ; 8,315 ; 9,105 ; 9,131 ; 10,35$ )

Sidman, M. Delayed-punishment effects mediated by competing behavior. J. comp. physiol. Psychol., 1954, 47, 145-147. (4, 187; 5, 41; 5, 247)

Sidman, $M$. The temporal distribution of avoidance responses. J. comp. physiol. Psychol., 1954, 47, 399-402. (1, 183; 2, 227; 3, 323; 5, 247; 5, 271; 5,$391 ; 6,361 ; 6,415 ; 6,477 ; 8,9$ )

Sidman, $M$. On the persistence of avoidance behavior. J. abnorm. soc. Psychol., 1955, 50, 217 220. $(1,183 ; 8,9 ; 8,269 ; 9,421 ; 10,291)$

Sidman, M. Some properties of the warning stimulus in avoidance behavior. $J$. comp. physiol. Psychol., 1955, 48, 444-450. (1, 167; 1,$301 ; 5,271 ; 5,353 ; 6,47 ; 6,301 ; 6,477$; 7,$129 ; 8,329 ; 8,419 ; 9,703 ; 10,131 ; 10,485$ )

Sidman, M., Brady, J. V., Boren, J. J., Conrad, D. G., and Schulman, A. Reward schedules and behavior maintained by intracranial selfstimulation. Science, 1955, 122, 830-831. (2, 43; 3,$93 ; 7,285 ; 8,75$ )

Sidman, M. Technique for assessing the effects of drugs on timing behavior. Science, 1955, 122, 925. $(1,45 ; 1,359 ; 2,91 ; 3,93 ; 4,219 ; 4,263$; $4,327 ; 5,105 ; 5,467 ; 5,497 ; 6,281 ; 8,107)$

Sidman, M. Drug-behavior interaction. Ann. N. Y. 
Acad. Sci., 1956, 65, 282-302. (1, 59; 1, 207; 2, $91 ; 2,185 ; 5,105 ; 5,467 ; 5,473 ; 6,281 ; 6$, $477 ; 6,507 ; 7,97 ; 9,389 ; 10,485)$

Sidman, M. Time discrimination and behavioral interaction in a free operant situation. $J$. comp. physiol. Psychol., 1956, 49, 469-473. (1, $59 ; 1,109 ; 2,91 ; 3,183 ; 4,219 ; 4,263 ; 4$, $277 ; 5,105 ; 5,423 ; 6,39 ; 6,163 ; 6,281 ; 6$, $399 ; 6,549 ; 7,119 ; 7,415 ; 8,19 ; 8,107 ; 8$, $255 ; 8,347 ; 9,619 ; 10,425)$

Sidman, M. and Boren, J. J. The relative aversiveness of warning signal and shock in an avoidance situation. J. abnorm. soc. Psychol., 1957, 55, 339-344. (6, 519; 10, 451; 10, 485)

Sidman, M. and Boren, J. J. A comparison of two types of warning stimulus in an avoidance situation. J. comp. physiol. Psychol., 1957, 50, 282-287. (5, 271; 6, 47;6, 301; 7, 129; 9, 389; $9,703 ; 10,291 ; 10,485)$

Sidman, M., Herrnstein, R. J., and Conrad, D. G. Maintenance of avoidance behavior by unavoidable shocks. J. comp. physiol. Psychol., 1957, 50, 553-557. (1, 183; 1, 207; 1, 265; 3, 35; 3,$349 ; 4,17 ; 5,19 ; 5,353 ; 5,423 ; 6,29 ; 6$, $507 ; 6,549 ; 7,405 ; 9,177 ; 10,95 ; 10,131)$

Sidman, M. and Boren, J. J. The use of shockcontingent variations in response-shock intervals for the maintenance of avoidance behavior. J. comp. physiol. Psychol., 1957, 50, 558-562. (5, 97; 5, 271; 6, 477; 6, 507)

Sidman, M. Conditioned reinforcing and aversive stimuli in an avoidance situation. Trans. N.Y. Acad. Sci., 1957, 19, 534-544. (2, 133; 6, 519; 8, 419; 10, 451)

Sidman, M. Behavioral pharmacology. Psychopharmacologia, 1959, 1, 1-19. (5, 105; 5, 323; 6, 293)

Sidman, M. An adjustable avoidance schedule. Paper read at EPA, Atlantic City, April 1959. $(2,133 ; 3,155 ; 5,271 ; 6,537)$

Sidman, M. Tactics of scientific research. New York: Basic Books, 1960. (4, 149; 5, 61; 5, 113; 6,$39 ; 6,449 ; 6,607 ; 7,191 ; 8,31 ; 8,107 ; 8$, $315 ; 8,405 ; 9,581 ; 9,671 ; 9,691)$

Sidman, M. Normal sources of pathological behavior. Science, 1960, 132, 61-68. (6, 507; 6, $575 ; 8,135$ )

Sidman, M. Time-out from avoidance as a conditioned positive reinforcer. Paper read at Psychon. Soc., Chicago, Sept. 1960. (5, 391; 5,$423 ; 6,525$ )

Sidman, M. Operant techniques. In A. J. Bachrach (Ed.), Experimental foundations of clinical psychology. New York: Basic Books, 1962. Pp. 170-210. (6, 431; 7, 139)

Sidman, M. and Stoddard, L. T. Programming perception and learning for retarded children. In N. R. Ellis (Ed.), International review of research in mental retardation. Vol. 2. New
York: Academic Press, 1966. Pp. 151-208. (10, $3 ; 10,261$ )

Sidowski, J. B., Wyckoff, L. B., and Tabory, L. The influence of reinforcement and punishment in a minimal social situation. J. abnorm. soc. Psychol., 1956, 2, 115-119. (9, 691)

Siegel, P. S. and Siegel, H. S. The effect of emotionality on the water intake of the rat. $J$. comp. physiol. Psychol., 1949, 42, 12-16. (6, 209) Siegel, P. S. and Brantley, J. J. The relationship of emotionality to the consummatory response of eating. J. exp. Psychol., 1951, 42, 304-306. $(6,209)$

Siegel, P. S. Concept formation: response-time considerations. Psychol. Rep., 1964, 14, 435-442. (7, 408)

Siegel, S. Nonparametric statistics for the behavioral sciences. New York: McGraw-Hill, 1956. (2, 165; 4, 209; 4, 371; 7, 369;8, 117; $10,119 ; 10,131 ; 10,219 ; 10,319)$

Silva, E. E., Estable, C., and Segundo, J. P. Further observations on animal hypnosis. Arch. Ital. Biol., 1959, 97, 156-166. (9, 63)

Simmons, M. W. Operant discrimination learning in human infants. Child Develpm., 1964, 35, 737-748. (9, 105)

Simon, A. (Ed.) The physiology of emotions. Springfield, Ill.: Thomas, 1961. (6, 477)

Simpson, R. and Valenstein, E. S. An inexpensive swivel-device for electrical stimulation of unrestrained animals. EEG clin. Neurophysiol., 1963, 15, 900-901. (9, 17)

Skinner, B. F. Drive and reflex strength, I and II. J. gen. Psychol., 1932, 6, 22-48. (5, 239) '

Skinner, B. F. The generic nature of the concepts of stimulus and response. J. gen. Psychol., $1935,12,40-65$. $(10,375)$

Skinner, B. F. Two types of conditioned reflex and a pseudo type. J. gen. Psychol., 1935, 12, 66-77. $(5,383)$

Skinner, B. F. Two types of conditioned reflex: a reply to Konorski and Miller. J. gen. Psychol., 1937, 16, 272-279. (5, 383; 8, 405)

Skinner, B. F. and Heron, W. T. Effects of caffeine and Benzedrine upon conditioning and extinction. Psychol. Rec., 1937, 1, 340-346. (3, 293; 5, 105)

Skinner, B. F. The behavior of organisms. New York: Appleton Century, 1938. (More than 100 citations)

Skinner, B. F. A method of maintaining an arbitrary degree of hunger. J. comp. Psychol., 1940, 30, 139-145. (1, 221)

Skinner, B. F. The nature of the operant reserve. Psychol. Bull., 1940, 37, 423. (Abstract) (1, 221)

Skinner, B. F. The operational analysis of psychological terms. Psychol. Rev., 1945, 52, 270-277. $(3,21)$

Skinner, B. F. Differential reinforcement with re- 
spect to time. Amer. Psychologist, 1946, 1, 274 275. (Abstract) $(4,149)$

Skinner, B. F. and Campbell, S. L. An automatic shocking-grid apparatus for continuous use. $J$. comp. physiol. Psychol., 1947, 40, 305-307. (5, $511 ; 9,173 ; 10,291$ )

Skinner, B. F. "Superstition" in the pigeon. J. exp. Psychol., 1948, 38, 168-172. (1, 103; 1, 265; 2, $151 ; 3,221 ; 4,171 ; 5,61 ; 5,113 ; 5,175 ; 5$, $279 ; 5,511 ; 5,543 ; 6,203 ; 6,301 ; 6,371$; 6,$477 ; 6,525 ; 7,351 ; 9,191 ; 9,337 ; 9,547$; 9,$581 ; 10,131$ )

Skinner, B. F. Are theories of learning necessary? Psychol. Rev., 1950, 57, 193-216. (1, 109; 1, 221; 2,$65 ; 3,9 ; 3,259 ; 4,45 ; 4,97 ; 4,149 ; 6$, $53 ; 6,399 ; 7,361 ; 8,97 ; 9,443 ; 9,655)$

Skinner, B. F. Science and human behavior. New York: Macmillan, 1953. (1, 45; 1, 87; 1, 281; 4,$7 ; 4,203 ; 5,73 ; 5,113 ; 5,383 ; 5,391 ; 5$, $543 ; 6,223 ; 6,477 ; 7,345 ; 8,31 ; 8,405 ; 9$, $105 ; 9,267$ )

Skinner, B. F. Some contributions of an experimental analysis of behavior to psychology as a whole. Amer. Psychologist, 1953, 8, 69-78. $(1,183 ; 1,221 ; 6,431 ; 7,1)$

Skinner, B. F. The science of learning and the art of teaching. Harv. educ. Rev., 1954, 24, 86-97. $(3,275 ; 5,279 ; 7,327 ; 8,357 ; 8,385)$

Skinner, B. F. Verbal behavior. New York: Appleton-Century-Crofts, 1957. (1, 173; 2, 151; 3, $275 ; 4,197 ; 5,363 ; 5,383 ; 6,179 ; 7,327 ; 9$, $213 ; 10,461)$

Skinner, B. F. The experimental analysis of behavior. Amer. Scientist, 1957, 45, 343-371. (1, $235 ; 3,27 ; 4,7 ; 4,97 ; 7,263$ )

Skinner, B. F. and Morse, W. H. Concurrent activity under fixed-interval reinforcement. $J$. comp. physiol. Psychol., 1957, 50, 279-281. (1, 371; 8, 305; 9, 95; 9, 337)

Skinner, B. F. Teaching machines. Science, 1958, 128, 969-977. (3, 275; 3, 292; 4, 360; 5, 279; $6,223)$

Skinner, B. F. Cumulative record. New York: Appleton-Century-Crofts, 1959. (4, 133)

Skinner, B. F. Pigeons in a pelican. Amer. Psychologist, 1960, 15, 28-37. (7, 361)

Skinner, B. F. Why we need teaching machines. Harv. educ. Rev., 1961, 31, 377-398. (10, 3)

Skinner, B. F. Behaviorism at fifty. Science, 1963, 140, 951-958. (8, 405)

Skinner, B. F. Reflections on a decade of teaching machines. In R. Glaser (Ed.), Teaching machines and programmed learning: II. Data and directions. Washington, D.C.: Nat. Educ. Assn., 1965. Pp. 5-20. (10, 261)

Sluckin, W. Imprinting and early learning. Chicago: Aldine, 1965. (9, 177)

Smelik, P. G. Failure to inhibit corticotrophin secretion by experimentally induced increases in corticoid levels. Acta endocr., Copenh., 1963, 44, 36-46. (10, 555)

Smith, A. H., Winget, C. M., and Kelly, C. F. Growth and survival of birds under chronic acceleration. Growth, 1959, 23, 97. (8, 315)

Smith, C. B. Effects of $d$-amphetamine upon operant behavior of pigeons: enhancement by reserpine. J. Pharmacol. exp. Therap., 1964, $146,167-174 .(9,389 ; 10,485)$

Smith, J., Kimeldorf, D., and Hunt, E. Motor responses of moths to low-intensity x-ray exposure. Science, 1963, 140, 805-806. $(9,29)$

Smith, M. H., Jr. and Hoy, W. J. Rate of response during operant discrimination, J. exp. Psychol., 1954, 48, 259-264. (3, 35; 3, 289; 4, 57; $4,179 ; 4,335 ; 6,131 ; 8,269 ; 10,251)$

Smith, Margaret F. and Smith, K. U. Thirst-motivated activity and its extinction in the cat. J. gen. Psychol., 1939, 21, 89-98. (5, 239; 8, 29)

Smith, O. A., Jr. and Stebbins, W. C. Conditioned blood flow and heart rate in monkeys. J. comp. physiol. Psychol., 1965, 59, 432-436. (9, 681)

Smith, S. and Hosking, E. Birds fighting. London: Faber \& Faber, 1955. (6, 73; 7, 223; 9, 191)

Smith, W. I. and Ross, S. The social behavior of vertebrates: a review of the literature (19391950). Psychol. Bull., 1952, 49, 598-627. (10, 387)

Smock, C. D. and Holt, Bess G. Children's reactions to novelty: an experimental study of "curiosity motivation." Child Develpm., 1962, 33, 631-642. $(9,119)$

Snapper, A. G. Properties of behavior under response-independent temporally defined reinforcement schedules. Doctoral dissertation, Columbia, 1962. $(6,623)$

Snapper, A. G., Ferraro, D. P., Schoenfeld, W. N., and Locke, B. Adaptation of the white rat's cardiac rate to testing conditions. J. comp. physiol. Psychol., 1965, 59, 128-131. (8, 17)

Snedecor, G. W. Statistical methods. Ames, Iowa: Iowa State College Press, 1946. (4, 309)

Snelbecker, G. E., Sherman, L. S., Rothstein, E., and Cramer, H. Programmed instruction and neuropsychiatric diabetic patients: a preliminary study. J. program. Instruc., 1963, 2, 47-51. $(8,385)$

Snell, G. D., Fekete, E., Hummel, K. P., and Law, $\mathrm{L}$. W. The relation of mating, ovulation, and the estrous smear in the house mouse to time of day. Anat. Rec., 1940, 76, 39-54. (10, 219)

Solomon, R. L. Latency of response as a measure of learning in a "single-door" discrimination. Amer. J. Psychol., 1943, 56, 422-432. (4, 57)

Solomon, R. L., Kamin, L. J., and Wynne, L. C. Traumatic avoidance learning: the outcomes of several extinction procedures with dogs. $J$. abnorm. soc. Psychol., 1953, 48, 291-302. (1, $183 ; 4,17 ; 6,449 ; 9,53 ; 9,421 ; 10,131$ ) 
Solomon, R. L. and Wynne, L. C. Traumatic avoidance learning: acquisition in normal dogs. Psychol. Monogr., 1953, 67 (4, Whole No. 354). $(4,17 ; 5,391 ; 9,421)$

Solomon, R. L. and Brush, Elinor S. Experimentally derived conceptions of anxiety and aversion. In M. R. Jones (Ed.), Nebraska symposium on motivation, 1956. Lincoln: Univ. Nebr. Press, 1956. Pp. 212-305. (4, 17; 4, 309; 9, 421)

Solomon, R. L. Punishment. Amer. Psychologist, $1964,19,239-253$. (7, 409; 8, 41; 9, 53; 9, 421)

Sommer, R. and Osmond, H. Symptoms of institutional care. Social Problems, 1961, 8, 254-262. $(8,357)$

Spector, W. S. Growth rate of Sherman, albino, rats, and Wistar, albino, rats. In W. S. Spector (Ed.), Handbook of biological data. WADC Tech. Rep. 56-273, ASTIA Doc. No. AD 110501. Wright Air Dev. Center: Nat. Acad. Sci., Nat. Res. Council, 1956. (2, 165)

Spence, $\mathbf{K}$. W. The nature of discrimination learning in animals. Psychol. Rev., 1936, 43, 427449. $(4,289 ; 5,279 ; 6,171 ; 6,223 ; 7,233$; $10,467)$

Spence, $\mathrm{K}$. W. The differential response in animals to stimuli varying within a single dimension. Psychol. Rev., 1937, 44, 430-444. (5, 435; 6, 171; 7,$217 ; 8,263$ )

Spence, K. W. Continuous versus non-continuous interpretations of discrimination learning. Psychol. Rev., 1940, 47, 271-288. (1, 87; 5, 543; 9, 593)

Spence, K. W. The basis of solution by chimpanzees of the intermediate size problem. J. exp. Psychol., 1942, 31, 247-271. (8, 263)

Spence, $\mathrm{K}$. W. The role of secondary reinforcement in delayed reward learning. Psychol. Rev., $1947,54,1-8 .(5,543)$

Spence, K. W. Theoretical interpretations of learning. In S. S. Stevens (Ed.), Handbook of experimental psychology. New York: Wiley, 1951. Pp. 690-729. (5, 543)

Spence, K. W. Learning and performance in eyelid conditioning as a function of intensity of the UCS. J. exp. Psychol., 1953, 45, 57-63. (9, 605)

Spence, K. W. Behavior theory and conditioning. New Haven: Yale Univ. Press, 1956. (4, 133; 4, 309; 4, 383; 5, 481; 5, 543; 7, 401)

Spence, K. W. Behavior theory and learning. Englewood Cliffs, N.J.: Prentice-Hall, 1960. (7, 135)

Spence, K. W., Homzie, M. J., and Rutledge, E. F. Extinction of the human eyelid $\mathrm{CR}$ as a function of the discriminability of the change from acquisition to extinction. J. exp. Psychol., $1964,67,545-552 .(9,601)$

Speranskaya, E. N. Operative methods and the conduct of chronic physiological experiments in dogs. Moscow: Akad. Nauk SSSR, 1953. $(8,405)$
Sperry, R. W. and Clarke, E. Interocular transfer of visual discrimination habits in a teleost fish. Physiol. Zool., 1949, 22, 372-378. (9, 11)

Spiker, C. C. Effects of stimulus similarity on discrimination learning. J. exp. Psychol., 1956, 51, 393-395. $(6,1)$

Spiker, C. C. Stimulus pretraining and subsequent performance in the delayed reaction experiment. J. exp. Psychol., 1956, 52, 107-111. (2, 151)

Spiker, C. C. Performance on a difficult discrimination following pre-training with distinctive stimuli. Child Develpm., 1959, 30, 513-521. (5, 279)

Spock, B. The common sense book of baby and child care. New York: Duell, Sloan \& Pierce, 1957. $(5,525)$

Staats, A. W. A case in and a strategy for the extension of learning principles to problems of human behavior. In A. W. Staats (Ed.), Human learning. New York: Holt, Rinehart \& Winston, 1964. Pp. 121-144. (7, 139)

Staats, A. W., Minke, K. A., Finley, J. R., Wolf, M., and Brooks, L. O. A reinforcer system and experimental procedure for the laboratory study of reading acquisition. Child Developm., 1964, 35, 209-231. (7, 139)

Stachnik, T. J., Ulrich, R. E., and Mabry, J. H. Reinforcement of aggression through intracranial stimulation. Psychon. Sci., 1966, 5, 101-102. $(10,131)$

Stacy, R. W. and Waxman, B. D. (Eds.) Computers in biomedical research. Vol. 1. Electronic data processing-medicine. New York: Academic Press, 1965. (9, 163)

Staddon, J. E. R. The effect of "knowledge of results" on timing behavior in the pigeon. Doctoral dissertation, Harvard, 1963. (8, 19)

Staddon, J. E. R. Reinforcement as input: cyclic variable-interval schedule. Science, 1964, 145, 410-412. (10, 349)

Staddon, J. E. R. and Innis, Nancy K. Preference for fixed vs. variable amounts of reward. Psychon. Sci., 1966, 4, 193-194. (10, 417)

Staddon, J. E. R. and Innis, Nancy K. An effect analogous to "frustration" on interval reinforcement schedules. Psychon. Sci., 1966, 4, 287288. $(10,45 ; 10,349)$

Stanley, W. C. and Aamodt, M. S. Force of responding during extinction as a function of the force requirement during conditioning. J. comp. physiol. Psychol., 1954, 47, 51-56. (6, 179)

Stebbins, W. C. and Sidman, M. Satiation effects under fixed ratio schedules of reinforcement. J. comp. physiol. Psychol., 1954, 47, 114-116. (5, 391)

Stebbins, W. C. Relation of amount of primary 
reinforcement to discrimination and to secondary reinforcement strength. $J$. comp. physiol. Psychol., 1959, 52, 721-726. (2, 351; 5, 305; 6, 387)

Stebbins, W. C., Lundin, R. W., and Lyon, D. O. The effect of alcohol upon reaction time in the white rat. Psychol. Rec., 1960, 10, 15-19. (4, 149; 5,305 )

Stein, L. and Brady, J. V. Reinforcement percentage varied within individual subjects as a factor in the extinction of conditioned "fear." Paper read at EPA, New York, April 1957. (2, 357)

Stein, L. Secondary reinforcement established with subcortical reinforcement. Science, 1958, 127, 466-467. $(5,543)$

Stein, L. and Ray, O. S. Self-regulation of brainstimulating current intensity in the rat. Science, 1959, 130, 570-571. (7, 69; 8, 75)

Stein, L. and Ray, O. S. Brain stimulation reward "thresholds" self-determined in rat. Psychopharmacologia, 1960, 1, 251-256. (7, 69)

Stein, L. An analysis of stimulus-duration preference in self-stimulation of the brain. $J$. comp. physiol. Psychol., 1962, 55, 405-414. (8, 75)

Stein, L. Amphetamine and neural reward mechanisms. In H. Steinberg (Ed.), Animal behavior and drug action, Ciba Found. Symposium. Boston: Little, Brown, 1964. Pp. 91-113. (8, 75)

Stein, L. Excessive drinking in the rat: superstition or thirst? J. comp. physiol. Psychol., 1964, 58, 237-242. (9, 19; 9, 37; 10, 199)

Stellar, E. and Hill, J. H. The rat's rate of drinking as a function of water deprivation. J. comp. physiol. Psychol., 1952, 45, 96-102. (2, 271; 5, $89 ; 6,209 ; 8,295$ )

Stelter, C. J., Barnes, H. W., and Homme, L. E. An investigation of precision timing in the rat. Amer. Psychologist, 1959, 14, 421. (Abstract) $(4,299 ; 8,219)$

Stephens, J. M. The influence of symbolic punishment and reward upon strong and upon weak associations. J. gen. Psychol., 1941, 25, 177-185. $(5,541)$

Stevens, J. C. and Shickman, G. M. The perception of repetition rate. J. exp. Psychol., 1959, 58, 433-440. (8, 47)

Stevens, S. S. Mathematics, measurement, and psychophysics. In S. S. Stevens (Ed.), Handbook of experimental psychology. New York: Wiley, 1951. Pp. 1-49. (6, 525)

Stevens, S. S. On the psychophysical law. Psychol. Rev., 1957, 64, 153-181. (5, 15; 5, 487)

Stevenson, Joan G. The effects of two schedules of primary and secondary reinforcement on resistance to extinction. Honors thesis, Mt. Holyoke, 1960. $(5,505)$
Stevenson, Joan G. Effects of ordering and spacing of test stimuli on the post-discrimination gradient of generalization. Doctoral dissertation, Brown, 1964. $(9,457)$

Stockham, M. A. Changes of plasma and adrenal corticosterone levels in the rat after repeated stimuli. J. Physiol., 1964, 173, 149-159. (10, 555)

Stodart, E. and Myers, K. A comparison of behavior, reproduction, and mortality of wild and domestic rabbits in confined populations. CSIRO Wildl. Res., 1964, 9, 144-159. (10, 219)

Stoddard, L. T. Operant conditioning of timing behavior in children. Doctoral dissertation, Columbia, 1962. (8, 107)

Stone, C. P. and Ferguson, L. W. Temporal relationships in the copulatory acts of adult male rats. J. comp. physiol. Psychol., 1940, 30, 419433. (10, 219)

Stone, G. C., Calhoun, D. W., and Klopfenstein, $M$. $H$. The interresponse interval as a measure of bar pressing behavior in normal and drugged rats. J. comp. physiol. Psychol., 1958, 51, 315-319. (2, 271)

Stone, G. C. Effects of some centrally acting drugs upon learning of escape and avoidance habits. J. comp. physiol. Psychol., 1960, 53, 33-37. (4, 309)

Stone, G. R. The effect of negative incentives in serial learning: II. Incentive intensity and response variability. J. gen. Psychol., 1950, 42, 179-224. (8, 385)

Storms, L. H., Boroczi, G., and Brown, W. E., Jr. Punishment inhibits an instrumental response in hooded rats. Science, 1962, 135, 1133-1134. $(7,409)$

Storms, L. H., Boroczi, G., and Brown, W. E., Jr. The effects of punishment as a function of strain of rat and duration of shock. J. comp. physiol. Psychol., 1963, 56, 1022-1026. (10, 95)

Strassburger, R. C. Resistance to extinction of a conditioned operant as related to drive level at reinforcement. J. exp. Psychol., 1950, 40, 473-487. $(1,221)$

Stricker, E. M. and Miller, N. E. Thirst measured by licking reinforced on interval schedules: effects of prewatering and bacterial endotoxin. J. comp. physiol. Psychol., 1965, 59, 112-115. $(10,571)$

Strominger, J. L. The relation between water intake in normal rats and in rats with hypothalamic hyperphagia. Yale J. biol. Med., 1946, 19, 279-288. (9, 37)

Suppes, P. and Ginsberg, R. Experimental studies of mathematical concept formation in young children. Sci. Educ., 1962, 46, 230-240. (10, 3)

Sutherland, N. S. Visual discrimination of orientation by octopus. Brit. J. Psychol., 1957, 48, 5571. $(9,11 ; 9,567)$

Sutherland, N. S. Visual discrimination of orienta- 
tion and shape by octopus. Nature, 1957, 179, 11-13. $(9,11)$

Sutherland, N. S. Theories of shape discriminations in octopus. Nature, 1960, 186, 840-844. $(9,11)$

Sutherland, N. S. Cat's ability to discriminate oblique rectangles. Science, 1963, 139, 209-210. $(9,11)$

Sutton, D. and Miller, J. M. Implanted electrodes: cable coupler for elimination of movement artifact. Science, 1963, 140, 988-989. (8, 181; 9, 17)

Swanson, E. E. Short acting barbituric acid derivatives. Proc. Soc. exp. Biol. Med., 1934, 31, 963964. (6, 125)

Swinnen, M. E. T. One-shot relay has fewer components. Electronic Design, 1964, 8, 106. (9, $27 ; 10,515)$

Symmes, D. Self-determination of critical flicker frequencies in monkeys. Science, 1962, 136, 714-715. (9, 501)

Szentagothai, J., Flerko, B., Mess, B., and Halasz, B. Hypothalamic control of the anterior pituitary. Budapest: Akademiai Kiado, 1962. (10, 571)

Taber, J. I. Human timing behavior. Doctoral dissertation, Univ. Pittsburgh, 1961. (6, 431)

Tainter, M. L. Effects of certain analeptic drugs on spontaneous running activity of the white rat. J. comp. Psychol., 1943, 36, 143-155. (4, 327)

Tamura, M. The effects of some central nervous system depressants on conflict behavior in dogs. Jap. J. Pharmacol., 1963, 13, 133-142. (10, 565)

Taylor, D. W. Learning telegraphic code. Psychol. Bull., 1943, 40, 461-487. (1, 1)

Taylor, K. F. and Sluckin, W. An experiment in tactile imprinting. Bull. Brit. psychol. Soc., 1964, 17 (54), 10A. $(9,177)$

Taylor, R. B. Arc suppression techniques. In R. N. Auger (Ed.), The relay guide. New York: Reinhold, 1960. (8, 415)

Tedeschi, R. E. Effects of various centrally acting drugs on fighting behavior of mice. J. Pharmacol. exp. Therap., 1959, 125, 28. (5, 511; 6, 620; 7, 223)

Teichner, W. H. Experimental extinction as a function of the inter-trial intervals during conditioning and extinction. J. exp. Psychol., 1952, 44, 170-178. (5, 339)

Teichner, W. H. Recent studies of simple reaction time. Psychol. Bull., 1954, 51, 128-149. (4, 149)

Teitelbaum, P. Random and food-directed activity in hyperphagic and normal rats. J. comp. physiol. Psychol., 1957, 50, 486-490. (6, 563)

Teitelbaum, P. and Campbell, B. A. Ingestion patterns in hyperphagic and normal rats. $J$. comp. physiol. Psychol., 1958, 51, 135-141. (2, 271)
Teitelbaum, P. and Derks, P. The effect of amphetamine on forced drinking in the rat. $J$. comp. physiol. Psychol., 1958, 51, 801-810. (5, $105 ; 6,395 ; 8,107 ; 9,389 ; 10,485$ )

Tepperman, J. Metabolic and endocrine physiology. Chicago: Year Book Med. Pub., 1962. $(10,555)$

Terrace, H. S. Errorless discrimination learning in the pigeon: effects of chlorpromazine and imipramine. Science, 1963, 140, 318-319. (9, 1; 9, $11 ; 9,155)$

Terrace, H. S. Wavelength generalization after discrimination learning with and without errors. Science, 1964, 144, 78-80. (9, 1; 9, 457; 9, $613 ; 9,631 ; 10,361$ )

Terrace, H. S. Behavioral contrast and the peak shift. Paper read at Psychon. Soc., Chicago, Oct. 1965. $(9,613)$

Terrace, H. S. Stimulus control. In W. K. Honig (Ed.), Operant behavior: areas of research and application. New York: Appleton-CenturyCrofts, 1966. Pp. 271-344. (9, 305; 9, 593; 9, $613 ; 10,17 ; 10,243 ; 10,349 ; 10,361$ )

Thomas, D. R. and King, R. A. Stimulus generalization as a function of level of motivation. J. exp. Psychol., 1959, 57, 323-328. (2, 307; 4, $31 ; 4,157 ; 5,19 ; 5,375$ )

Thomas, D. R. Stimulus generalization and operant discrimination as a function of level of motivation. Doctoral dissertation, Duke, 1961. (6, 171)

Thomas, D. R. and Lopez, L. J. The effects of delayed testing on generalization slope. J. comp. physiol. Psychol., 1962, 55, 541-544. (6, 171)

Thomas, D. R. 'The effects of drive and discrimination training on stimulus generalization. $J$. exp. Psychol., 1962, 64, 24-28. (6, 171; 9, 239; 9, 457; 10, 361)

Thomas, D. R. and Barker, E. G. The effects of extinction and "central tendency" on stimulus generalization in pigeons. Psychon. Sci., 1964, 1, 119-120. (9, 457)

Thomas, Doris H. Effects of discrimination reversal training on stimulus generalization. Master's thesis, Duke, 1962. (6, 171)

Thomas, J. R. Time out avoidance from a behavior-independent contingency. Psychon. Sci., 1965, 3, 217-218. $(9,435)$

Thomas, J. R. and Stubbs, A. Enhancement of fixed-ratio performance by briefly presented conditioned reinforcing stimuli. Psychon. Sci., $1966,5,329-330$. (10, 45; 10, 175; 10, 331)

Thompson, D. M. Time-out from fixed-ratio reinforcement: a systematic replication. Psychon. Sci., 1965, 2, 109-110. (8, 189)

Thompson, M. E. A two-factor theory of inhibition. Psychol. Rev., 1960, 67, 200-206. (5, 481)

Thompson, T. Effects of chlorpromazine on "aggressive" responding in the rat. J. comp. 
physiol. Psychol., 1961, 54, 398-400. (6, 155; 9, 205)

Thompson, $T$. The effect of two phenothiazines and a barbiturate on extinction-induced rate increase of a free-operant. J. comp. physiol. Psychol., 1962, 55, 714-718. (6, 155; 9, 205)

Thompson, $T$. Visual reinforcement in Siamese fighting fish. Science, 1963, 141, 55-57. (8, 341; 8, 397)

Thompson, W. R. Social behavior. In Anne Roe and G. Simpson (Eds.), Behavior and evolution. New Haven: Yale Univ. Press, 1958. Pp. 291-310. (5, 383)

Thorndike, E. L. Educational psychology. Vol. 2. The psychology of learning. New York: Teachers College, 1913. (1, 1; 10, 467)

Tinbergen, N. and van Iersel, J. J. Displacement reactions in the Three-spined Stickleback. $B e$ havior, 1947, 1, 56-63. (7, 45)

Tinbergen, N. The study of instinct. London: Oxford Univ. Press, 1951. (7, 45; 7, 223; 8, 75; 9, 233; 10, 131)

Tinbergen, N. Social behavior in animals. New York: Wiley, 1953. (7, 223)

Tinbergen, N. The function of territory. Bird Study, 1957, 4, 14-27. (7, 45)

Tinker, M. A. Intelligence in an intelligence test with an auditory distractor. Amer. J. Psychol., 1925, 36, 467-468. (1, 183)

Tintner, G. Econometrics. New York: Wiley, 1952. $(9,619)$

Titlebaum, L. F., Falk, J. L., and Mayer, J. Altered acceptance and rejection of $\mathrm{NaCl}$ in rats with diabetes insipidus. Amer. J. Physiol., 1960, 199, 22-24. (9, 111)

Tolcott, M. A. Conflict: a study of some interactions between appetite and aversion in the white rat. Genet. Psychol. Monogr., 1948, 38, 83-142. (9, 703; 10, 75)

Tolles, W. E. Computers in medicine and biology. Ann. N.Y. Acad. Sci., 1964, 115, 543-1140. (9, 163)

Tolman, C. W. Social facilitation of feeding behavior in the domestic chick. Animal Behav., 1964, 12, 245-251. (10, 387)

Tolman, C. W. and Wilson, G. F. Social feeding in domestic chicks. Animal Behav., 1965, 13, 134-142. (10, 387)

Tolman, C. W. Emotional behavior and social facilitation of feeding in domestic chicks. Animal Behav., 1965, 13, 493-496. (10, 387)

Tormey, J. and Lasagna, L. Relation of thyroid function to acute and chronic effects of amphetamine in the rat. J. Pharmacol. exp. Therap., 1960, 128, 201-209. (4, 327)

Towe, A. L. and Morse, R. W. Dependence of the response characteristics of somatosensory neutrons on the form of their afferent input. Exp. Neurol., 1962, 6, 407-425. (9, 135)
Tracy, W. H. Changes in noise-maintained behavior following septal forebrain lesions in the albino rat. Doctoral dissertation, Boston Univ., 1956. (9, 357)

Trapold, M. A. and Fowler, H. Instrumental escape performance as a function of the intensity of noxious stimulation. J. exp. Psychol., 1960, 60, 323-326. (6, 519)

Trapold, M. A. and Odom, P. B. The transfer of a discrimination and discrimination-reversal between two manipulation-defined responses. Paper read at MPA, St. Louis, May 1964. (7, 401)

Travis, R. P. and Sparks, D. L. The influence of unilateral and bilateral spreading depression during learning upon subsequent relearning. J. comp. physiol. Psychol., 1963, 56, 56-59. (7, 350)

Travis, R. P. The role of spreading cortical depression in relating the amount of avoidance training to interhemispheric transfer. J. comp. physiol. Psychol., 1964, 57, 42-46. (7, 350)

Trevarthen, C. B. Double visual learning in splitbrain monkeys. Science, 1962, 136, 258-259. (8, 147)

Trotter, J. R. The physical properties of barpressing behavior and the problem of reactive inhibition. Quart. J. exp. Psychol., 1956, 8, 97-106. $(1,149 ; 2,335 ; 4,317 ; 6,179 ; 8,1$; 8,231 )

Trotter, J. R. The bar-pressing recorder. Quart. J. exp. Psychol., 1956, 8, 182-184. (2, 335)

Trotter, J. R. The timing of bar-pressing behavior. Quart. J. exp. Psychol., 1957, 9, 78-87. (2, 335; 4,$317 ; 10,149$ )

Tsao, J. C. Studies in spaced and massed learning: I. Time period and amount of learning. Quart. J. exp. Psychol., 1948, 1, 29-36. (5, 15)

Tuge, K. H., Shima, I., and Koga, K. Defensive conditioned reflexes in pigeons. Sechenov. $J$. Physiol. USSR, 1957, 43, 766-776. (2, 213; 9, 681)

Tuge, H. and Shima, I. Defensive conditioned reflex after destruction of the forebrain in pigeons. J. comp. Neurol., 1959, 111, 427-445. $(9,681)$

Tuge, $H$. and Shima, I. EEG and conditioned reflexes in the pigeon. Physiol. biochemoslov., 1960, 9, 465-471. (9, 681)

Tuge, H. and Yueh, C. H. Functional compensation of the somatic and visceral components of the defensive conditioned reflexes after decerebration in young pigeons. Activitas nerv. superior, 1962, 4, 275-283. (9, 681)

Tulloss, R. E. The learning curve: with special reference to the progress of students in telegraphy and typewriting. Doctoral dissertation, Harvard, 1918. (1, 1)

Turner, R. N. Operant control of the vocal be- 
havior of a dolphin. Doctoral dissertation, Univ. California, Los Angeles, 1962. (9, 535)

Turner, R. N. Methodological problems in the study of cetacean behavior. In W. N. Tavolga (Ed.), Marine bio-acoustics. Oxford: Pergamon Press, 1964. Pp. 337-350. (9, 535)

Ullman, L. The experimental production and analysis of a "group eating symptom" in rats. J. comp. physiol. Psychol., 1951, 44, 575-581. (7, 409)

Ulmer, F. A., Jr. So you'd like a pet monkey? America's First Zoo, 1954, 6, 14-17. (6, 249)

Ulmer, F. A., Jr. The monkey: a comparison of the natural environment with observations in captivity. Ann. N.Y. Acad. Sci., 1960, 85, 737-746. $(6,249)$

Ulrich, R. E., Johnston, M., Richardson, J., and Wolff, P. The operant conditioning of fighting behavior in rats. Psychol. Rec., 1963, 13, 465-470. (10, 131; 10, 395)

Ulrich, R. E., Wolff, P. C., and Azrin, N. H. Shock as an elicitor of intra- and inter-species fighting behavior. Animal Behav., 1964, 12, 14-15. (8, $55 ; 9,401 ; 10,311$ )

Ulrich, R. E. and Craine, W. H. Behavior: persistence of shock-induced aggression. Science, 1964, 143, 971-973. (8, 55; 10, 131; 10, 311)

Ulrich, R. E., Hutchinson, R. R., and Azrin, N. H. Pain-elicited aggression. Psychol. Rec., 1965, 15, 111-126. (10, 311)

Ulrich, R. E., Stachnik, T. J., Brierton, G. R., and Mabry, J. H. Fighting and avoidance in response to aversive stimulation. Behavior, 1966, 26, 124-129. (10, 131; 10, 311)

Umberger, E. J. A laboratory holder for immobilizing experimental rats. J. lab. clin. Med., 1946, 31, 369-371. (9, 143)

Underwood, B. J. A graphical description of rote learning. Psychol. Rev., 1957, 64, 119-122. (3, 71)

Underwood, B. J., Ham, M., and Eckstrand, B. Cue selection in paired-associate learning. $J$. exp. Psychol., 1962, 64, 405-409. (9, 469)

Uttal, W. R. The use of a summary card-punch to generate stimuli and to collect data simultaneously. Amer. J. Psychol., 1962, 75, 150-151. (6, 599)

Valenstein, E. S., Hodos, W., and Stein, L. A simplified electrode-assembly for implanting chronic electrodes in the brains of small animals. Amer. J. Psychol., 1961, 74, 125-128. (7, $183 ; 8,75$ )

Valenstein, E. S. and Beer, B. Reinforcing brain stimulation in competition with water reward and shock avoidance. Science, 1962, 137, 1052 1054. (10, 571)

Valenstein, E. S. and Myers, W. J. Rate-indepen- dent test of reinforcing consequences of brain stimulation. J. comp. physiol. Psychol., 1964, 57, 452-460. $(9,514)$

Valenstein, E. S. Problems of measurement and interpretation with reinforcing brain stimulation. Psychol. Rev., 1964, 71, 415-437. (7, 285; 10, 281)

Valenstein, E. S. and Valenstein, T. Interaction of positive and negative reinforcing neural systems. Science, 1964, 145, 1456-1458. (10, 75)

van Iersel, J. J. A. and Bol, A. C. A. Preening of two tern species: a study on displacement. Behavior, 1958, 13, 1-88. (7, 351)

van Neumann, J. Distribution of the ratio of the mean square successive difference to the variance. Ann. math. Statist., 1941, 12, 367-395. $(10,555)$

Verhave, $T$. The effects of varying the concentration of a sucrose solution used as a reinforcing agent in a chaining situation. Doctoral dissertation, Columbia, 1955. (2, 351)

Verhave, T. Differential effects of $d$-desoxyephedrine, caffeine and picrotoxin on operant behavior. J. Pharmacol. exp. Therap., 1957, 119, 174. (Abstract) $(1,207)$

Verhave, T., Owen, J. E., Jr., and Robbins, E. B. Effects of secobarbital and pentobarbital on escape and avoidance behavior. Psychol. Rep., 1957, 3, 421-428. $(9,267)$

Verhave, T., Owen, J. E., Jr., and Slater, O. H. Effects of various drugs on escape and avoidance behavior. Progr. Neurobiol., 1958, 3, 267301. (6, 293)

Verhave, T. Recent developments in the experimental analysis of behavior. In Proc. 11th Res. Conf., Amer. Meat Inst. Found., Univ. of Chicago. Chicago: Univ. Chicago, 1959. Pp. 113136. $(3,35 ; 3,349 ; 4,7 ; 5,19 ; 5,391 ; 6,525)$

Verhave, T., Owen, J. E., and Robbins, E. B. The effect of morphine sulfate on avoidance and escape behavior. J. Pharmacol. exp. Therap., 1959, 125, 248-251. (2, 271)

Verhave, T. Permanence of effect produced by delayed termination of warning stimulus in an avoidance situation. Psych. Rep., 1959, 5, 31-38. $(2,151 ; 6,477 ; 8,71)$

Verhave, $T$. Technique for differential reinforcement of rate of avoidance responding. Science, $1959,129,959-960$. $(2,185 ; 4,187 ; 5,423 ; 6$, $301 ; 6,563 ; 9,641$ )

Verhave, T. A depressant effect of methamphetamine on avoidance behavior. Fed. Proc., 1961, 20, 395. (9, 389; 10, 485; 10, 555)

Verhave, T. A demonstration of an avoidance schedule preference. Paper read at EPA, New York, April 1961. (5, 391)

Verhave, $T$. Toward a calculus of reinforcement value. Paper read at APA, New York, Sept. 1961. $(5,391 ; 6,525)$ 
Verhave, T. Strength of time-out from avoidance behavior as a function of time-out duration. Paper read at Psychon. Soc., St. Louis, Oct. 1962. (5, 391; 6, 525)

Verplanck, W. S. The development of a discrimination in a simple locomotor habit. J. exp. Psychol., 1942, 31, 441-464. (4, 57)

Verplanck, W. S. and Hayes, J. R. Eating and drinking as a function of maintenance schedule. J. comp. physiol. Psychol., 1953, 46, 327333. (5, 543; 6, 445)

Verplanck, W. S. The control of the content of conversation: reinforcement of statements of opinion. J. abnorm. soc. Psychol., 1955, 51, 668-676. $(4,25 ; 4,197)$

Verplanck, W. S. Operant conditioning of human motor behavior. Psychol. Bull., 1956, 53, 70-83. $(3,183)$

Verplanck, W. S. A glossary of some terms used in the objective science of behavior. Psychol. Rev., 1957, 64, 1-42. (7, 45)

Verzeano, M. and Finesinger, J. E. An automatic analyzer for the study of speech in interaction and in free association. Science, 1949, 110, 4546. $(2,179 ; 7,99)$

Voronin, L. G. Some results of comparative-physiological investigations of higher nervous activity. Psychol. Bull., 1962, 59, 161-195. (9, 681)

Waelsch, H. Blood-brain barrier and gas exchange. In H. Waelsch (Ed.), Biochemistry of the developing nervous system. New York: Academic Press, 1955. Pp. 187-207. $(9,95)$

Wagman, W. Sodium chloride deprivation: development of sodium chloride as a reinforcement. Science, 1963, 140, 1403-1404. (8, 295)

Wagner, A. R. The role of reinforcement and non-reinforcement in an "apparent frustration effect." J. exp. Psychol., 1959, 57, 130-136. (9, 205)

Wagner, A. R. Effects of amount and percentage of reinforcement and number of acquisition trials on conditioning and extinction. $J$. exp. Psychol., 1961, 62, 234-242. (7, 135)

Wagner, A. R. Conditioned frustration as a learned drive. J. exp. Psychol., 1963, 66, 142-148. (9, 205; 10, 439)

Walker, E. L. Learning. Annual Rev. Psychol., 1957, 8, 113-138. (5, 543)

Walker, K. C. The effect of a discriminative stimulus transferred to a previously unassociated response. J. exp. Psychol., 1942, 31, 313321. (1, 103; 7, 401)

Wallis, W. A. and Roberts, H. V. Statistics: a new approach. Glencoe, Ill.: Free Press, 1956. (7, $211 ; 8,347$ )

Walls, G. L. The vertebrate eye. Bloomfield Hills, Mich.: Cranbrook Press, 1942. (7, 361)

Walter, D. O. Spectral analysis for electroencepha- lograms: mathematical determination of neurophysiological relationships from records of limited duration. Exp. Neurol., 1963, 8, 155181. $(9,619)$

Walters, G. C. and Rogers, J. V. Aversive stimulation of the rat: long term effects on subsequent behavior. Science, 1963, 142, 70-71. (9, 521)

Warden, C. J. Animal motivation studies: the albino rat. New York: Columbia Univ. Press, 1931. $(9,251)$

Warner, L. H. The association span of the white rat. J. genet. Psychol., 1932, 41, 57-90. (2, 133)

Warren, A. B. and Brown, R. H. Conditioning operant response phenomena in children. $J$. gen. Psychol., 1943, 28, 181-207. (4, 233)

Warren, J. M. Additivity of cues in a visual pattern discrimination by monkeys. J. comp. physiol. Psychol., 1953, 46, 484-486. (10, 17)

Warren, J. M. Primate learning in comparative perspective. In A. M. Schrier, H. F. Harlow, and F. Stollnitz (Eds.), Behavior of nonhuman primates. Vol. 1. New York: Academic Press, 1965. Pp. 249-281. (9, 593)

Wasman, M. and Flynn, J. P. Directed attack elicited from hypothalamas. Arch. Neurol., 1962, 6, 220-227. (9, 401)

Watson, J. B. The effect of delayed feeding upon learning. Psychobiology, 1917, 1, 51-59. (10, 67)

Weeks, J. R. Experimental morphine addiction: method for automatic intravenous injections in unrestrained rats. Science, 1960, 138, 143144. $(9,385)$

Weeks, J. R. Methods and materials for chronic intravenous injections in relatively unrestrained rats. Document No. 7304, ADI, Auxiliary Publications Project, Library of Congress, Washington, D.C., 1962. (8, 107)

Weeks, J. R. and Davis, J. D. Chronic intravenous cannalas for rats. J. appl. Physiol., 1964, 19, 540-541. (9, 385; 10, 571)

Weiner, I. H. and Stellar, E. Salt preference of the rat determined by a single-stimulus method. J. comp. physiol. Psychol., 1951, 44, 394-401. $(9,111)$

Weinstein, B. The evolution of intelligent behavior in rhesus monkeys. Genet. Psychol. Monogr., 1945, 31, 3-48. (10, 529)

Weinstock, S. Resistance to extinction of a running response following partial reinforcement under widely spaced trials. J. comp. physiol. Psychol., 1954, 47, 318-323. (7, 135)

Weinstock, S. Acquisition and extinction of a partially reinforced running response at a 24hour intertrial interval. J. exp. Psychol., 1958, 56, 151-158. (5, 481)

Weiskrantz, L. and Wilson, W. A. The effects of reserpine on emotional behavior of normal and brain operated monkeys. Ann. N.Y. Acad. Sci., 1955, 61, 36-55. (5, 259) 
Weiskrantz, L. Discussion of first symposium. In P. B. Bradley, P. Deniker, and C. RadoucoThomas (Eds.), Proc. First int. Congr. Neuropsychopharmacol. Vol. 1. Princeton: Elsevier, 1959. Pp. 53-56. (5, 259)

Weiss, B., Coleman, P. D., and Green, R. F. A stochastic model for time-ordered dependencies in continuous scale repetitive judgments. J. exp. Psychol., 1955, 50, 237-244. (9, 619)

Weiss, B. and Moore, E. W. Drive level as a factor in distribution of responses in fixedinterval reinforcement. J. exp. Psychol., 1956, 52, 82-84. (7, 337; 8, 183)

Weiss, B. Thermal behavior of the subnourished and pantothenic acid-deprived rat. J. comp. physiol. Psychol., 1957, 50, 481-485. (5, 543)

Weiss, B. and Laties, V. G. Fractional escape and avoidance on a titration schedule. Science, $1958,128,1575-1576 .(2,227 ; 6,219 ; 6,563)$

Weiss, B. and Laties, V. G. Amphetamine toxicity in rats subjected to aversive stimulation. Fed. Proc., 1959, 18, 457. (4, 17)

Weiss, B. and Laties, V. G. Changes in pain tolerance and other behavior produced by salicylates. J. Pharmacol. exp. Therap.,. 1961, 131, 120-129. $(6,563 ; 8,315)$

Weiss, B. and Laties, V. G. Behavioral thermoregulation. Science, 1961, 133, 1338-1344. (6, 563; 8,$107 ; 8,203$ )

Weiss, B. and Laties, V. G. Drug effects on the temporal patterning of behavior. Fed. Proc., 1964, 23, 801-807. (9, 507)

Weiss, B. and Laties, V. G. Reinforcement schedule generated by an on-line digital computer. Science, 1965, 148, 658-661. (9, 163; 9, 581; 9, 619)

Weiss, R. F. Response speed, amplitude, and resistance to extinction as joint functions of work and reinforcement ratio. Doctoral dissertation, Yale, 1958. $(7,207)$

Weiss, S. J. Summation of response strengths instrumentally conditioned to stimuli in different sensory modalities. J. exp. Psychol., 1964, 68, 151-155. (10, 535)

Weissman, A. Behavior under some discriminative paradigms within a temporally defined framework of reinforcement schedules. Doctoral dissertation, Columbia, 1958. (3, 49; 4, 365)

Weissman, A. Nondiscriminated avoidance behavior in a large sample of rats. Psychol. Rep., $1962,10,591-600$. $(6,477)$

Weissman, A. Effect of electroconvulsive shock intensity and seizure pattern on retrograde amnesia in rats. J. comp. physiol. Psychol., $1963,56,806-810$. $(9,663)$

Weissman, A. Correlation between baseline nondiscriminated avoidance behavior in rats and amphetamine-induced stimulation. Psychopharmacologia, 1963, 4, 294-297. (10, 485)
Weitzman, E. D., Ross, G. S., Hodos, W., and Galambos, R. Behavioral method for study of pain in the monkey, Science, 1961, 133, 37-38. $(6,219)$

Weitzman, E. D. and Ross, G. S. A behavioral method for the study of pain perception in the monkey: the effects of some pharmacological agents. Neurology, 1962, 12, 264-272. (10, 109)

Welker, W. I. Variability of play and exploratory behavior in chimpanzees. J. comp. physiol. Psychol., 1956, 49, 181-185. (1, 87)

Welker, W. I. Free versus forced exploration of a novel situation by rats. Psychol. Rep., 1957, 3, 95-108. (5, 185)

Welty, J. C. Experiments in group behavior of fishes. Physiol. Zool., 1934, 7, 85-128. (10, 387)

Wendt, G. R. Two-and-one-half-year retention of a conditioned response. J. gen. Psychol., 1937, 17, 178-180. (6, 575; 9, 659)

Wenrich, $W$. W. The tact relation: an experiment in verbal behavior. Doctoral dissertation, Univ. Minnesota, 1962. (6, 247)

Wentink, E. A. The effects of certain drugs and hormones upon conditioning. J. exp. Psychol., 1938, 22, 150-163. (3, 293; 5, 105)

Wenzel, Bernice M. Relative resistance to reserpine of responses based on positive as compared with negative reinforcement. J. comp. physiol. Psychol., 1959, 52, 673-681. (5, 259; 5, 335)

Wenzel, Bernice M. Tactile stimulation as reinforcement for cats and its relation to early feeding experience. Psychol. Rep., 1959, 5, 297 300. $(2,288 ; 8,29)$

Wenzel, Bernice $M$. Changes in heart rate associated with responses based on positive and negative reinforcement. J. comp. physiol. Psychol., 1961, 54, 638-644. (6, 61; 8, 17)

Wenzel, Bernice M., Baldwin, B. A., and Tschirgi, R. D. Effects of intracarotid infusions of potassium chloride and sodium chloride on learned behavior in goats. Physiologist, 1963, 6, 295. $(7,263)$

Werdegar, D., Johnson, D. G., and Mason, J. W. A technique for continuous measurement of arterial blood pressure in unanesthetized monkeys. J. appl. Physiol., 1964, 19, 519-521. (7, 367)

Wetherbee, D. K. Comparative phylembryogenetic dimensionality of neonated birds. Ann Arbor, Mich.: Univ. Microfilms, 1959. (5, 265)

Wetherbee, $\mathbf{D}$. K. Investigations in the life history of the common coturnix. Amer. Midland Naturalist, 1961, 65, 168-186. (5, 265)

Wetherbee, D. K. and Jacobs, K. F. Migration of the common Coturnix in North America. Bird-banding, 1961, 32, 85-91. (5, 265)

White, B. W. Complexity and heterogeneity in the visual recognition of two-dimensional forms. 
In J. W. Wulfeck and J. H. Taylor (Eds.), Form discrimination as related to military problems. Washington, D.C.: Nat. Acad. Sci., Nat. Res. Council, 1957. (5, 279)

White, $C$. The use of ranks in a test of significance for comparing two treatments. Biometrics, 1952, 8, 33-41. (5, 317)

Whiteis, U. E. Punishment's influence on fear and avoidance. Harv. educ. Rev., 1956, 26, 360-373. $(9,53)$

Wickens, D. D., Schroder, H. M., and Snide, J. D. Primary stimulus generalization of the GSR under two conditions. J. exp. Psychol., 1954, 47, 52-56. $(4,371)$

Wike, E. L. and Barrientos, G. Secondary reinforcement and multiple drive reduction. $J$. comp. physiol. Psychol., 1958, 51, 640-643. (5, 543)

Wikler, A. Sites and mechanisms of action of morphine and related drugs in the central nervous system. Pharmacol. Rev., 1950, 2, 435-506. (2, 271)

Wikler, A. Rationale of the diagnosis and treatment of addictions. Conn. State med. J., 1955, 19, 560. $(10,235)$

Wikler, $A$. On the nature of addiction and habituation. Brit. J. Addict., 1961, 57, 73-79. (10, 235)

Wikler, A. Conditioning factors in opiate addiction and relapse. In D. M. Wilner and G. G. Kassebaum (Eds.), Narcotics. New York: McGrawHill, 1965. Pp. 85-100. (10, 235)

Wilcox, H. H. Changes accompanying aging in the brain of guinea pigs. J. Geront., 1951, 6, 168. (Abstract) $(2,219)$

Wilcoxin, F. Some approximate statistical proce dures. Stamford, Conn.: American Cyanamid, 1949. $(8,315)$

Williams, C. The elimination of tantrum behaviors by extinction procedures. J. abnorm. soc. Psychol., 1959, 59, 269. (8, 357)

Williams, D. The structure of emotions reflected in epileptic experiences. Brain, 1956, 79, 26-67. $(2,43)$

Williams, D. R. and Teitelbaum, P. Control of drinking behavior by means of an operantconditioning technique. Science, 1956, 124, 1294-1296. (5, 61; 7, 91; 7, 105)

Williams, D. R. Classical conditioning and incentive motivation. In W. F. Prokasy (Ed.), Classical conditioning. New York: Appleton-Century-Crofts, 1965. Pp. 340-357. (7, 401; 9, 305; 10, 243)

Williams, D. R. Negative induction in instrumental behavior reinforced by central stimulation. Psychon. Sci., 1965, 2, 341-342. (9, 305; 10, 243)

Williams, D. R. and Barry, H. Counter conditioning in an operant conflict situation. J. comp. physiol. Psychol., 1966, 61, 154-156. (10, 301)

Williams, D. R. Relation between response ampli- tude and reinforcement. J. exp. Psychol., 1966, 71, 634-641. (10, 243)

Williams, S. B. Resistance to extinction as a function of the number of reinforcements. $J$. exp. Psychol., 1938, 23, 506-522. (1, 221; 4, 133; 4, 317; 7, 135)

Wilson, M. P. and Keller, F. S. On the selective reinforcement of spaced responses. J. comp. physiol. Psychol., 1953, 46, 190-193. (1, 25; 1, $45 ; 1,59 ; 2,91 ; 2,133 ; 3,93 ; 3,115 ; 3$, $183 ; 4,263 ; 4,299 ; 4,349 ; 5,473 ; 5,497$; 5,$543 ; 6,109 ; 6,115 ; 6,163 ; 6,281 ; 6,477$; $6,549 ; 7,369 ; 8,19 ; 8,107 ; 8,255 ; 10,151)$

Wilson, M. P. Periodic reinforcement interval and number of periodic reinforcements as parameters of response strength. J. comp. physiol. Psychol., 1954, 47, 51-56. (1, 45; 1, 221; 2, 1; 3, $255 ; 4,243 ; 4,267 ; 6,607 ; 8,255 ; 10,341$; $10,395)$

Wilson, R. S. Autonomic changes produced by noxious and innocuous stimuli. J. comp. physiol. Psychol., 1964, 58, 290-295. (10, 235)

Wilson, W. A., Jr. Two-choice behavior of monkeys. J. exp. Psychol., 1960, 59, 207-208. (7, 151)

Wilson, W. A., Jr., Oscar, M., and Bitterman, M. E. Probability-learning in the monkey. Quart. $J$. exp. Psychol., 1964, 16, 163-165. (7, 151)

Winer, B. J. Statistical principles in experimental design. New York: McGraw-Hill, 1962. (6, 575; 10, 495)

Winnick, Wilma A. Anxiety indicators in an avoidance response during conflict and nonconflict. J. comp. physiol. Psychol., 1956, 49, 52.59. (2, 23; 10, 75)

Winograd, E. Two parameters of escape behavior. Doctoral dissertation, Indiana, 1961. $(6,75)$

Winograd, E., Cohen, P. S., and Cole, B. K. Frequency and latency measures of the generalization of punishment. Psychon. Sci., 1965, 2, 321322. $(9,239)$

Wischner, G. J. Stuttering behavior and learning: a preliminary theoretical formulation. $J$. speech hear. Dis., 1950, 15, 324-325. (1, 173)

Wodinsky, J. and Bitterman, M. E. Discriminationreversal in the fish. Amer. J. Psychol., 1957, 70, 569-576. $(3,247)$

Wodinsky, J. and Bitterman, M. E. Partial reinforcement in the fish. Amer. J. Psychol., 1959, 72, 184-199. (7, 357)

Wodinsky, J. and Bitterman, M. E. Resistance to extinction in the fish after extensive training with partial reinforcement. Amer. J. Psychol., 1960, 73, 429-434. (7, 345; 7, 357)

Wodinsky, J., Behrend, E. R., and Bitterman, M. E. Avoidance conditioning in two species of fish. Animal Behav., 1962, 10, 76-78. (6, 47)

Wolf, M., Risley, T., and Mees, H. Application of operant conditioning procedures to the behav- 
ior problems of an autistic child. Behav. Res. Ther., 1964, 1, 305-312. (8, 357)

Wolfe, J. B. Effectiveness of token-rewards for chimpanzees. Comp. Psychol. Monogr., 1936, 12, 1-72. (5, 543; 7, 83)

Wolff, P. C., Burnstein, D. D., and Cannon, D. L. The use of schedules of reinforcement to regulate a collective team response rate. Psychol. Rec., 1964, 14, 57-70. (7, 191)

Woodbury, C. B. The learning of stimulus patterns by dogs. J. comp. physiol. Psychol., 1943, 35, 2940. $(6,477)$

Woods, P. J., Ruckelshaus, S. I., and Bowling, D. M. Some effects of "free" and "restricted" environmental rearing conditions upon adult behavior in the rat. Psychol. Rep., 1960, 6, 191200. $(5,185)$

Woodworth, R. S. Experimental psychology. New York: Holt, 1938. $(8,269)$

Woodworth, R. S. Reinforcement of perception. Amer. J. Psychol., 1947, 60, 119-124. (10, 479)

Woodworth, R. S. and Schlosberg, H. Experimental psychology. (Rev. ed) New York: Holt, 1954. $(5,317 ; 8,207)$

Woodworth, R. S. Dynamics of behavior. New York: Holt, 1958. (6, 101)

Word, T. J., Stern, J. A., Sines, J. O., and McDonald, D. G. The cardiac response of the albino rat: a preliminary report. Psychophysiol. Newsltr., 1959, 5, 11-15. (8, 17)

Worden, A. N. and Leahy, J. S. The behavior of rabbits. In E. S. E. Hafez (Ed.), The behavior of domestic animals. Baltimore: Williams \& Wilkens, 1962. Pp. 397-414. (10, 219)

Wrigley, C. Electronic computers and psychological research. Amer. Psychologist, 1957, 12, 501-508. $(9,163)$

Wulzen, R. and Bahrs, A. M. Effects of milk diet on guinea pigs. Amer. J. Physiol., 1941, 133, 500. $(2,219)$

Wunder, C. C. Food consumption of mice during continual centrifugation. Iowa Acad. Sci., 1961, $68,616-624 .(8,315)$

Wunder, C. C., Lutherer, L. O., and Dodge, C. H. Survival and growth of organisms during lifelong exposure to high gravity. Aerospace Med., 1963, 34, 5-11. (8, 315)

Wyckoff, L. B., Jr. The role of observing responses in discrimination learning. Part I. Psychol. Rev., 1952, 59, 431-442. (1, 87; 3, 275; 5, 3; 5, 49; 5,$229 ; 5,543 ; 8,305 ; 9,337 ; 9,469 ; 10,367$ )

Wyckoff, L. B. and Page, H. A. A grid for administering shock. Amer. J. Psychol., 1954, 67, 154. $(4,308 ; 9,173 ; 10,291)$

Wyckoff, L. B., Sidowski, J., and Chambliss, D. J. An experimental study of the relationship between secondary reinforcing and cue effects of a stimulus. J. comp. physiol. Psychol., 1958, 51, 103-109. $(4,1 ; 5,543)$
Wyckoff, L. B., Jr. Toward a quantitative theory of secondary reinforcement. Psychol. Rev., 1959, 66, 68-78. (5, 3; 5, 543; 8, 305; 10, 341)

Wyrwicka, W., Dobrzecka, C., and Tarnecki, R. On the instrumental conditioned reaction evoked by electrical stimulation of the hypothalamus. Science, 1959, 130, 336-837. $(7,263)$

Wyrwicka, W. and Dobrzecka, C. Relationship between feeding and satiation centers of the hypothalamus. Science, 1960, 132, 805-806. (7, 263)

Xhenseval, B. and Richelle, M. Behavioral effects of a long-term treatment with meprobamate in cats. Int. J. Neuropharmacol., 1965, 4, 1-12. (8, 45)

Yerkes, R. M. The instincts, habits and reactions of the frog. Psychol. Rev., Monogr. Suppl., 1903, 4 (1, Whole No. 17), 579-673. (9, 671)

Yerkes, R. M. Genetic aspects of grooming, a socially important primate behavior pattern. J. soc. Psychol., 1933, 4, 3-25. (1, 83)

Yerkes, R. M. Suggestibility in chimpanzee. J. soc. Psychol., 1934, 5, 271-282. (10, 387)

Yerkes, R. M. Chimpanzees: a laboratory colony. New Haven: Yale Univ. Press, 1943. (1, 83)

Yoshii, N. and Hockaday, W. J. Conditioning of frequency-characteristic repetitive electroencephalographic response with intermittent photic stimulation. EEG clin. Neurophysiol., 1958, 10, 487-502. $(5,467)$

Young, F. A. A primate control system. Proc. Animal Care Panel, 1957, 7, 127-137. (7, 229)

Young, P. T. Motivation of behavior. New York: Wiley, 1936. $(5,225)$

Young, P. T. Appetite, palatability and feeding habit: a critical review. Psychol. Bull., 1948, 45, 289-320. (4, 187)

Young, P. T. Palatability versus appetite as determinants of the critical concentrations of sucrose and sodium chloride. Comp. Psychol. Monogr., 1949, 19, 1-44. (9, 111)

Young, P. T. and Falk, J. L. The relative acceptability of sodium chloride as a function of concentration and water need. J. comp. physiol. Psychol., 1956, 49, 569-575. (9, 111)

Young, P. T. Isohedonic contour maps. Psychol. Rep., 1960, 7, 478. $(6,525)$

Young, W. C., Dempsey, E. W., and Myers, H. I. Cyclic reproductive behavior in the female guinea pig. J. comp. Psychol., 1935, 19, 313335. (10, 219)

Young, W. C. Observations and experiments on mating behavior in female mammals. Quart. Rev. Biol., 1941, 16, 135-156, 311-335. (10, 219)

Youtz, R. E. P. Reinforcement, extinction and spontaneous recovery in a non-Pavlovian re- 
action. J. exp. Psychol., 1938, 22, 305-310. (9, 251)

Zajonc, R. B. Social facilitation. Science, 1965, 149, 269-274. (10, 387)

Zeigler, H. P. and Wyckoff, L. B., Jr. Observing responses and discrimination learning. Quart. J. exp. Psychol., 1961, 13, 129-140. (10, 367)

Zeigler, H. P. and Schmerler, Susan. Visual discrimination of orientation by pigeons. Animal Behav., 1965, 13, 475-477. $(9,11 ; 9,567)$

Zeiler, M. D. The ratio theory of intermediate size discrimination. Psychol. Rev., 1963, 70, 516-533. (8, 263)

Zeman, W. and Innes, J. R. M. Craigie's neuroanatomy of the rat. New York: Academic Press, 1963. $(8,75 ; 10,517)$

Zimbardo, P. G. and Montgomery, K. C. Effects of "free-environment" rearing upon exploratory behavior. Psychol. Rep., 1957, 3, 589-594. $(5,185)$

Zimmerman, D. W. Durable secondary reinforce- ment: method and theory. Psychol. Rev., 1957, 64, 373-383. (3, 288; 5, 543; 9, 475; 10, 331)

Zimmerman, D. W. Sustained performance in rats based on secondary reinforcement. J. comp. physiol. Psychol., 1959, 22, 353-358. (5, 543)

Zimmerman, J. A multiple schedule of time out avoidance with monkeys. Amer. Psychologist, 1963, 18, 422. (Abstract) (8, 329; 9, 487)

Zimmerman, J. Technique for sustaining behavior with conditioned reinforcement. Science, 1963, 142, 682-684. $(8,125 ; 9,41 ; 9,475 ; 10,271$; $10,331)$

Zimmerman, J. and Hanford, P. V. Sustaining behavior with conditioned reinforcement as the only response-produced consequence. Psychol. Rep., 1966, 19, 391-401. (10, 331)

Zotterman, Y. Species differences in the water taste. Acta Physiol. Scand., 1956, 37, 60-70. (8, 295)

Zucker, L. Growth criteria. In Rat quality: a consideration of heredity, diet and disease, Proc. of Nat. Vit. Found. Symposium. New York: Nat. Vit. Found., 1953. (7, 119; 7, 391) 